CAROLINA DE LARA SHECAIRA

Avaliação da influência da produção de citocinas no perfil de resposta imunitária em bezerros nos primeiros 30 dias de vida

São Paulo

2017

CAROLINA DE LARA SHECAIRA 


\section{Avaliação da influência da produção de citocinas no perfil de resposta imunitária em bezerros nos primeiros 30 dias de vida}

Tese apresentada ao Programa de Pós-Graduação em Clínica Veterinária da Faculdade de Medicina Veterinária e Zootecnia da Universidade de São Paulo para a obtenção do título de Doutor em Ciências

\section{Departamento:}

Clínica Médica

Área de concentração:

Clínica Veterinária

\section{Orientador:}

Prof. Dr. Fernando José Benesi

São Paulo 
Autorizo a reproduçäo parcial ou total desta obra, para fins acadêmicos, desde que citada a fonte.

\section{DADOS INTERNACIONAIS DE CATALOGAÇÃO NA PUBLICAÇÃO}

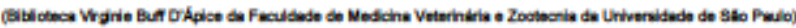

\begin{tabular}{|c|c|}
\hline \multirow[t]{6}{*}{$\begin{array}{l}\text { T. } 3557 \\
\text { FMVZ }\end{array}$} & 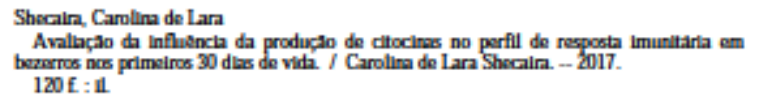 \\
\hline & 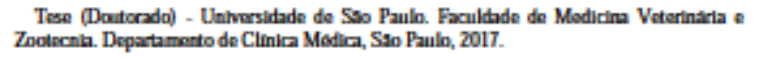 \\
\hline & Programa de Pas-Conduacha: Clinva Veterinarh. \\
\hline & Ára de consentraça: Clinira Votertnatia. \\
\hline & Orientador: Prof. Dr. Fesmando Jose BenesL1. \\
\hline & 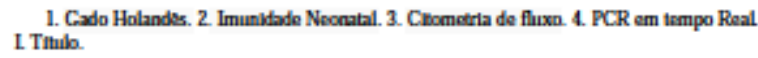 \\
\hline
\end{tabular}




\section{CERTIFICADO}

Certificamos que a proposta intitulada "Avaliação da influência da produção de citocinas no perfil de resposta imunitária em bezerros nos primeiros 30 dias de vida. ", protocolada sob o CEUA $n^{2} 2372210114$, sob a responsabilidade de Fernando José Benesi e equipe; Carolina de Lara Shecaira - que envolve a produçāo, manutençāo e/ou utilização de animais pertencentes ao filo Chordata, subfilo Vertebrata (exceto o homem), para fins de pesquisa cientifica ou ensino - está de acordo com os preceitos da Lei 11.794 de 8 de outubro de 2008, com o Decreto 6.899 de 15 de julho de 2009, bem como com as normas editadas pelo Conselho Nacional de Controle da Experimentaçăo Animal (CONCEA), e foi aprovada pela Comissāo de Ética no Uso de Animais da Faculdade de Medicina Veterinária e Zootecnia da Universidade de São Paulo (CEUA/FMVZ) na reunião de 06/04/2016.

We certify that the proposal "título em inglês", utilizing 20 Bovines (20 males), protocol number CEUA 2372210114, under the responsibility of Fernando José Benesi and team; Carolina de Lara Shecaira - which involves the production, maintenance and/or use of animals belonging to the phylum Chordata, subphylum Vertebrata (except human beings), for scientific research purposes or teaching - is in accordance with Law 11.794 of October 8, 2008, Decree 6899 of July 15, 2009, as well as with the rules issued by the National Council for Control of Animal Experimentation (CONCEA), and was approved by the Ethic Committee on Animal Use of the School of Veterinary Medicine and Animal Science (University of São Paulo) (CEUAFMVZ) in the meeting of 04/06/2016.

Finalidade da Proposta: Pesquisa

Vigência da Proposta: de 02/2014 a 02/2015 Área: Clínica Médica Veterinária

Origem: Não aplicável biotério

$\begin{array}{lllll}\text { Espécie: } & \text { Bovinos } & \text { sexo: Machos } & \text { idade: } 01 \text { a } 30 \text { dias } & \text { N: } 20 \\ \text { Linhagem: } & \text { Holandesa } & \text { Peso: } 30 \text { a } 70 \mathrm{~kg} & \end{array}$

Linhagem: Holandesa

Peso: $\quad 30$ a $70 \mathrm{~kg}$

Resumo: Avaliar o comportamento e a qualidade imunológica de 20 (vinte) bezerros nos primeiros 30 dias de vida, por meio de técnicas de PCR e Citometria de Fluxo.

Local do experimento: Hospital de Bovinos e pequenos ruminantes da Faculdade de Medicina Veterinária e Zootecnia da Universidade de Săo Paulo.

São Paulo, 18 de abril de 2017

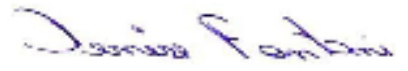

Profa. Dra. Denise Tabacchi Fantoni

Presidente da Comissão de Etica no Uso de Animais Faculdade de Medicina Veterinária e Zootecnia da Universidade de São Paulo

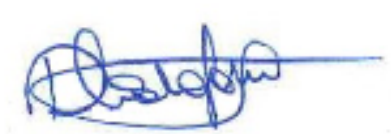

Roseli da Costa Gomes

Secretaria Executiva da Comissāo de Ética no Uso de Animais Faculdade de Medicina Veterinária e Zootecnia da Universidade de Săo Paulo 
FOLHA DE AVALIAÇÃO

Autor: SHECAIRA, Carolina de Lara

Título: Avaliação da influência da produção de citocinas no perfil de resposta imunitária em bezerros nos primeiros 30 dias de vida

Tese apresentada ao Programa de Pós-Graduação em Clínica Veterinária da Faculdade de Medicina Veterinária e Zootecnia da Universidade de São Paulo para obtenção do titulo de Doutor em Ciências

Data: 1

\section{Banca Examinadora}

Prof. Dr.

Instituição: Julgamento:

Prof. Dr.

Instituição: Julgamento:

Prof. Dr.

Instituição: Julgamento:

Prof. Dr.

Instituição: Julgamento:

Prof. Dr.

Instituição: Julgamento:

\section{DEDICATÓRIA}


A família Esaú Shecaira pela coragem, força e união que me permitiu chegar até aqui;

A família Lara pelo apoio e amor incondicional;

Aos animais utilizados em pesquisas, que nos permitem o aperfeiçoamento da medicina veterinária;

E especialmente a todos os pesquisadores brasileiros que lutam arduamente para a construção e evolução da ciência em nosso país, abdicando muitas vezes do seu próprio conforto, dedico. 


\section{AGRADECIMENTOS}

Primeiramente a Deus, que me sustenta todos os dias com sua destra vitoriosa, dando-me tantos motivos para ser grata.

Ao meu orientador, Professor Titular Fernando José Benesi, por esses anos de parceria e caminhada, pelas suas orientações e pelas portas que me abriu desde 2011, minha sincera gratidão. Sua confiança em meu trabalho foi a chave para inúmeros progressos. Obrigada, professor, pela imensa oportunidade!

Ao Professor Doutor Milton Ricardo Azedo, "Tio Chico", eu não tenho palavras suficientes para agradecer. Por ter me ensinado citometria de fluxo, pelas noites adentro fazendo as análises, pelas correções de todos os relatórios, trabalhos e tese, muito obrigada, eu não teria conseguido sem seu auxílio e disponibilidade!

A equipe "benesetes", que também faço parte, Caroline, Juliana, Gabriela e Elisa, muito obrigada pela amizade, pela ajuda com os bezerros, pelos momentos compartilhados, pela força e compreensão que vocês sempre me deram, vocês são ótimas! Eu não teria chegado até aqui sem vocês!

Aos bezerros que são a parte mais importante deste trabalho, minha mais profunda gratidão e respeito, vocês foram meu objeto de trabalho, mas também foram meus amigos que me alegraram em dias difíceis, e para sempre serão minha inspiração.

À Professora Doutora Heloisa Godoy Bertagnon, por ter me trilhado nos primeiros passos da PCR, pela ajuda com protocolos, orçamentos e demais dúvidas, muito obrigada!

Ao Professor Doutor Paulo Brandão, por toda a sua generosidade e disponibilidade, me abriu as portas do LABMAS, me ajudou, confiou no meu trabalho, muito obrigada!

A Doutora Sueli, técnica do LABMAS, por ter me recebido, me ajudado, e me ensinado quase tudo o que eu sei sobre PCR, pela paciência e gentileza, muito, muito obrigada!

À Professora Doutora Camila Freitas Batista, minha "madrinha científica" pela ajuda na vida acadêmica desde 2008, me corrigindo, me ensinando, me apoiando, também pela amizade sincera, muito, muito obrigada, Cá!

Ao Doutor Rafael Teixeira por ter generosamente me doado amostras de cDNA para os testes com a curva de eficiência.

Ao Professor Doutor Rogerio Batista dos Santos, pela amizade e auxílio nesses anos de caminhada acadêmica. 
A todos os amigos da pós-graduação que partilharam comigo: conhecimento, alegrias e dificuldades, vocês são todos especiais! Muito obrigada pela parceria nesta caminhada, desejo muito sucesso a vocês!

À doutoranda Bruna Stanigher pelo compartilhamento de bezerros, e claro, pela grande amizade, obrigada!

Aos residentes do CBPR pela ajuda, companheirismo e amizade, gratidão!

Aos alunos de IC, Felipe, Eric, Edlen e especialmente à Marcella, por toda a ajuda com os bezerros, ajuda no laboratório, pelos fins de semanas dispensados ao projeto, muito obrigada, e sucesso na caminhada!

À Secretária da Pós-graduação, Adelaide, por toda ajuda com os prazos, e normas, e pela amizade, e companheirismo, obrigada, Dê!

Aos professores do Departamento de Clínica Médica da FMVZ/USP, pelos ensinamentos, muito obrigada! Especialmente às professoras: Professora Associada Alice Della Libera e Professora Dra Viviani Gomes por todas as perguntas que me sanaram em qualquer lugar que fosse, Professora Associada Maria Cláudia Araripe Sucupira pelas vezes que me ouviu e me orientou. Ao professor Dr Fábio Pogliani, por me ouvir, por me orientar e pelas risadas e Professor Titular Enrico Ortolani pelos ensinamentos e pelo coaching profissional.

A todos os funcionários da FMVZ/USP e terceirizados que de alguma forma contribuíram para a realização deste trabalho, desempenhando suas funções com honestidade e generosidade, muito obrigada pela ajuda nestes anos.

Ao Walter, representante da Sunmoon e à Marlene, representante da Tecnofisher por todo o auxílio, disposição e pela amizade, agradeço.

À Faculdade de Medicina Veterinária e Zootecnia da Universidade de São Paulo, por ter me permitido cursar a pós-graduação, dando-me acesso a tecnologia e informação necessárias para o desenvolvimento e conclusão deste trabalho.

A Fundação de Amparo à Pesquisa de São Paulo pela concessão da bolsa de doutorado (Processo N 2014/02418-5) e pela concessão do auxílio pesquisa (Processo N 2013/253237) sem os quais seria impossível a realização deste trabalho e de outros trabalhos paralelos.

Aos meus familiares que compreenderam muitas vezes minha ausência, me apoiaram e vibraram comigo, muito obrigada!

Aos amigos que torceram por mim, me animaram e vibraram comigo, obrigada!

Ao meu marido Murilo por estar ao meu lado nos dias bons e nos dias maus, e principalmente nos dias que meu chão parecia ruir, Murilo, muito obrigada, eu não teria conseguido sem o seu suporte e paciência. 
Aos meus gatos, Buiu e Belota pelo amor incondicional. Por esperarem diariamente o meu retorno para casa, sempre felizes em me ver. Por serem minha companhia enquanto eu escrevia a tese e por serem a alegria da minha vida. 
"Se vi mais longe foi por estar de pé sobre ombros de gigantes." (Isaac Newton) 


\section{RESUMO}

SHECAIRA, C.L.. Avaliação da influência da produção de citocinas no perfil de resposta imunitária em bezerros nos primeiros 30 dias de vida. [Evaluation of the influence of cytokine production on the immune response profile of calves in the first 30 days of life]. 2017. 117f. Tese (Doutorado em Ciências) - Faculdade de Medicina Veterinária e Zootecnia, Universidade de São Paulo, São Paulo, 2017.

Os primeiros 30 dias pós-nascimento do bezerro, chamado período neonatal, é caracterizado por grande desenvolvimento imunológico. O sistema imune começa a se desenvolver ainda no início da gestação, porém, após o nascimento, mesmo que morfologicamente desenvolvido, não se apresenta totalmente funcional pela ausência de estímulos antigênicos. Ademais as particularidades anatômicas e fisiológicas da placentação dos bovinos são um impediente à transferência de imunidade durante a gestação, assim sendo o feto se desenvolve sem a influência das imunoglobulinas maternas, ficando altamente dependente ao início da vida extrauterina da transferência de imunidade passiva via colostro. As características do sistema imune do bezerro em seu período neonatal fazem com que este seja muito susceptível a doenças. Conhecer o comportamento imunitário dos bezerros recém-nascidos pode auxiliar a diminuir a incidência de doenças e o custo desse animal, além de aumentar o seu bem-estar. Deste modo, buscou-se avaliar o padrão de resposta imunitária do neonato nos primeiros 30 dias de vida, por meio de avaliações: da atividade fagocítica e do metabolismo oxidativo de neutrófilos circulantes e imunoenotipagem de linfócitos $\mathrm{T}\left(\mathrm{CD}^{+}\right)$e suas subpopulações $\left(\mathrm{CD}^{+}{ }^{+} \mathrm{CD}^{+}\right)$por citometria de fluxo e a expressão gênica das citocinas IL-4, IL-10, IL-12 e IFN- $\gamma$ por PCR em Tempo Real. O exame físico, o hemograma e avaliação de transferência de imunidade passiva foram considerados como critério de inclusão para garantir a sanidade dos animais durante o período experimental. Com base nos resultados obtidos nesta pesquisa para pode se concluir que: a atividade de fagocitose dos granulócitos foi constante nos 30 dias avaliados; a produção de espécies reativas de oxigênio por granulócitos foi observada nos ensaios basal e estimulado; e com comportamento semelhante, apresentando os dois ensaios, maiores porcentagens nos dias 1, 25 e 30 p.n.; os linfócitos $\mathrm{CD}^{+}$e suas subpopulações:CD4 ${ }^{+}$, $\mathrm{CD}^{+}$, estes apresentaram porcentagens semelhantes àquelas encontradas nos bovinos adultos; e a relação $\mathrm{CD}^{+} / \mathrm{CD}^{+}$aumentou aos 30 dias de vida, pelo aumento de $\mathrm{CD} 4^{+}$. Não foi possível mensurar a expressão gênica das citocinas IL-4 e IFN- $\gamma$ em nenhum dos momentos avaliados; no entanto, foi verificada a expressão gênica de citocinas IL-10 e IL-12, com uma 
inclinação para o perfil Th2 induzido pela expressão mais frequente de IL-10, observando-se influência da expressão gênica das citocinas IL-10 e IL-12 no leucograma, na atividade dos granulócitos, e nas subpopulações de linfócitos T.

Palavras-chave: Gado Holandês. Imunidade Neonatal. Citometria de fluxo, PCR em tempo Real. 


\begin{abstract}
SHECAIRA, C.L. Evaluation of the influence of cytokine production on the immune response profile of calves in the first 30 days of life. [Avaliação da influência da produção de citocinas no perfil de resposta imunitária em bezerros nos primeiros 30 dias de vida]. 2017. 117f. Tese (Doutorado em Ciências) - Faculdade de Medicina Veterinária e Zootecnia, Universidade de São Paulo, São Paulo, 2017.
\end{abstract}

The first 30 days post-birth of the calf, called the neonatal period, is characterized by large immunological development. The immune system begins to develop even at the beginning of gestation, but after birth, even if morphologically developed, it is not fully functional due to the absence of antigenic stimuli. In addition, the anatomical and physiological characteristics of bovine placentation are an impediment to the transfer of immunity during gestation, so the fetus develops without the influence of maternal immunoglobulins, being highly dependent at the beginning of the extrauterine life of the transference of passive immunity via colostrum. The characteristics of the immune system of the calf in its neonatal period make it very susceptible to diseases. Knowing the immune behavior of newborn calves can help reduce the incidence of diseases and the cost of this animal, and increase their well-being. The aim of this study was to evaluate the immune response pattern of the neonate in the first 30 days of life through evaluations of phagocytic activity and oxidative metabolism of circulating neutrophils and $\mathrm{T}$ lymphocyte $(\mathrm{CD} 3+)$ immuno-typing and its subpopulations $(\mathrm{CD} 4+$ and CD8 +) by flow cytometry and the gene expression of the IL-4, IL-10, IL-12 and IFN- $\gamma$ cytokines by Real-Time PCR. Physical examination, blood count and passive immunity assessment were considered as inclusion criteria to guarantee the health of the animals during the experimental period. Based on the results obtained in this research it can be concluded that: granulocyte phagocytosis activity was constant in the 30 days evaluated; the production of reactive oxygen species by granulocytes was observed in the basal and stimulated assays; and with similar behavior, presenting the two trials, highest percentages on days 1,25 and 30 p.n .; the CD3 + lymphocytes and their subpopulations: CD4 +, CD8 +, these presented percentages similar to those found in adult bovines; and the CD4 + / CD8 + ratio increased at 30 days of life, due to the increase in CD4 +. It was not possible to measure the gene expression of IL-4 and IFN- $\gamma$ cytokines in any of the evaluated moments; However, IL-10 and IL-12 cytokine gene expression was observed, with an inclination to the Th2 profile induced by the more frequent expression of IL-10, with the influence of the gene expression of the 
cytokines IL-10 and IL- 12 on leukogram, granulocyte activity, and T lymphocyte subpopulations.

Keywords: Holstein Cattle. Neonatal immunity. Flow cytometry. Real time PCR. 


\section{LISTA DE FIGURAS}

Figura 1 Citograma demonstrando o gate correspondente aos leucócitos sanguíneos com características de tamanho (FSC) e granulosidade (SSC) utilizado para a avaliação dos granulócitos das amostras de sangue por citometria de fluxo 46

Figura 2 Histograma demonstrando a porcentagem de células contendo marcador de superfície específico de granulócitos (CH138+) observadas no gate utilizado para a avaliação dos neutrófilos das amostras de sangue por citometria de fluxo

Figura 3 Dinâmica da contagem absoluta de leucócitos: linfócitos, monócitos e granulócitos, de 20 bezerros da raça Holandesa durante o primeiro mês de vida.

Figura 4 Produção de espécies reativas de oxigênio em granulócitos sem estimulo pela fagocitose de Staphylococcus aureus marcados com iodeto de propídio, de 20 bezerros da raça Holandesa durante o primeiro mês de vida: porcentagem e intensidade média de fluorescência (IMF). 83

Figura 5 Produção de espécies reativas de oxigênio em granulócitos com estimulo pela fagocitose de Staphylococcus aureus marcados com iodeto de propídio, de 20 bezerros da raça Holandesa durante o primeiro mês de vida: porcentagem e intensidade média de fluorescência (IMF).

Figura 6 Aumento de produção de espécies reativas de oxigênio por granulócitos frente ao estimulo pela fagocitose de Staphylococcus aureus marcados com iodeto de propídio, de 20 bezerros da raça Holandesa durante o primeiro mês de vida: porcentagem e intensidade média de fluorescência (IMF).

Figura 7 Variação da porcentagem de granulócitos (CH138+) observados no gate utilizado para os ensaios de fagocitose e metabolismo oxidativo, em 20 bezerros da raça Holandesa durante o primeiro mês de vida

Figura 8 Dinâmica da porcentagem de granulócitos fagocitando Staphylococcus aureus marcados com iodeto de propídio e da intensidade desta fagocitose (IMF) em 20 bezerros da raça Holandesa durante o primeiro mês de vida. 86

Figura 9 Dinâmica da porcentagem de granulócitos fagocitando Staphylococcus aureus e da intensidade desta fagocitose (IMF), por células que não estavam produzindo espécies reativas de oxigênio, em 20 bezerros da raça Holandesa durante o primeiro mês de vida.

Figura 10 Dinâmica da porcentagem de granulócitos fagocitando Stapylococcus aureus marcados com iodeto de propídio, por células que estavam produzindo espécies reativas de oxigênio, bem como a intensidade da fagocitose (IMF) e a intensidade da produção de 
espécies reativas de oxigênio IMF), em 20 bezerros da raça Holandesa durante o primeiro mês de vida

Figura 11 Dinâmica do aumento da intensidade de fagocitose de Stapylococcus aureus marcados com iodeto de propídio, por granulócitos que também estavam produzindo espécies reativas de oxigênio, em relação aos que não estavam produzindo, em 20 bezerros da raça Holanda durante o primeiro mês de vida 89 Figura 12 Dinâmica da porcentagem de granulócitos produzindo espécies reativas de oxigênio sem fagocitose de Staphylococcus aureus marcados por iodeto de propídio, e intensidade desta produção (IMF), em 20 bezerros da raça Holandesa durante o primeiro mês de vida.... 89 Figura 13 Gráfico do aumento da intensidade de produção de EROs (IMF) por granulócitos fagocitando SaPI, em relação aos granulócitos que não estavam fagocitando SaPI, em 20 bezerros da raça Holandesa durante o primeiro mês de vida .

Figura 14 Quantificação das subpopulações de linfócitos T: porcentagem de células CD3 ${ }^{+}$, $\mathrm{CD}^{+}, \mathrm{CD}^{+}$e a razão entre as subpopulações $\mathrm{CD} 4^{+} / \mathrm{CD}^{+}$em 20 bezerros da raça Holandesa durante o primeiro mês de vida

Figura 15 Expressão gênica das citocinas IL-10 e IL-12 por leucócitos de 20 bezerros da raça Holandesa no primeiro mês de vida. 


\section{LISTA DE TABELAS}

Tabela 1 Resultados médios ( \pm erro padrão da média) dos valores observados na avaliação bioquímica sérica de 20 bezerros da raça Holandesa, durante o primeiro mês de vida.

Tabela 2. Valores médios ( \pm erro padrão da média) observados no eritrograma de 20 bezerros da raça Holandesa, durante o primeiro mês de vida.

Tabela 3 Valores médios ( \pm erro padrão) ou medianos (com intervalo interquartil: Q1-Q3) dos índices hematimétricos observados no eritrograma de 20 bezerros da raça Holandesa, durante o primeiro mês de vida.

Tabela 4 Valores medianos (com intervalo interquartil: Q1-Q3) da contagem total e diferencial de leucócitos observados no leucograma de 20 bezerros da raça Holandesa, durante o primeiro mês de vida.

Tabela 5 Valores medianos (com intervalo interquartil: Q1-Q3) da porcentagem de células produzindo EROs frente ao estímulo por meio da fagocitose de SaPI, em granulócitos obtidos de 20 bezerros da raça Holandesa, durante o primeiro mês de vida.

Tabela 6 Valores medianos (com intervalo interquartil: Q1-Q3) da intensidade de produção de EROs frente ao estímulo por meio da fagocitose de SaPI, por granulócitos obtidos de 20 bezerros da raça Holandesa durante o primeiro mês de vida.

Tabela 7 Valores medianos (com intervalo interquartil:Q1-Q3) da fagocitose de SaPI por granulócitos obtidos de 20 bezerros da raça Holandesa, durante o primeiro mês de vida 65

Tabela 8 Valores medianos (com intervalo interquartil: Q1-Q3) da procentagem de células fagocitando SaPI e produzindo EROs, da intensidade da fagocitose e intensidade da produção de EROs, em granulócitos obtidos em 20 bezerros da raça Holandesa, durante o primeiro mês de vida.

Tabela 9 Valores medianos (com intervalo interquartil:Q1-Q3) da porcentagem e células fagocitando SaPI, sem produção de EROs, e da intensidade de fagocitose ( sem produção de EROs), em granulócitos obtidos em 20 bezerros da raça Holandesa, durante o primeiro mês de vida.

Tabela 10 Valores medianos (com intervalo interquartil: Q1-Q3) da porcentagem de células produzindo EROs e da intensidade desta produção em granulócitos que não estavam fagocitando SaPI, obtidos de 20 bezerros da raça Holandesa, durante o primeiro mês de vida. 
Tabela 11Valores medianos (com intervalo interquartil Q1-Q3) da quantificação das subpopulações de linfócitos T (CD3+) circulantes, obtidos de 20 bezerros da raça Holandesa, durante o primeiro mês de vida. ..... 76 Tabela 12 Medianas (com intervalo interquartil:Q1-Q3) da expressão gênica de citocinas IL10 e IL-12, em função da expressão observada no primeiro mês de vida, por leucócitos obtidos de 20 bezerros da raça Holandesa, durante o primeiro mês de vida..... 80 


\section{LISTA DE GRÁFICOS}

Gráfico 1 -Box plot da porcentagem de granulócitos produzindo EROs sem estímulo por SaPI, em 20 bezerros da raça Holandesa durante o primeiro mês de vida

Gráfico 2 - Box plot da porcentagem de granulócitos produzindo EROs com estímulo por SaPI, em 20 bezerros da raça Holandesa durante o primeiro mês de vida. .61

Gráfico 3 - Box plot da intensidade de produção de EROs por granulócitos sem estímulo por SaPI, em 20 bezerros da raça Holandesa durante o primeiro mês de vida 63

Gráfico 4 -Box plot da intensidade de produção de EROs por granulócitos com estímulo por SaPI, em 20 bezerros da raça Holandesa durante o primeiro mês de vida. 64

Gráfico 5 - Box plot da porcentagem de granulócitos realizando fagocitose de SaPI, em 20 bezerros da raça Holandesa durante o primeiro mês de vida. .66

Gráfico 6 - Box plot da intensidade de fagocitose de SaPI por granulócitos, em 20 bezerros da raça Holandesa durante o primeiro mês de vida. .66

Gráfico 7 - Box plot da porcentagem de granulócitos realizando fagocitose de SaPI com produção de EROs, em 20 bezerros da raça Holandesa durante o primeiro mês de vida

Gráfico 8 - Box plot da intensidade de fagocitose de SaPI com produção de EROs, por granulócitos, em 20 bezerros da raça Holandesa durante o primeiro mês de vida.

Gráfico 9- Box plot da intensidade de produção de EROs por granulócitos fagocitando SaPI, em 20 bezerros da raça Holandesa durante o primeiro mês de vida. 70

Gráfico 10 - Box plot da porcentagem de granulócitos produzindo EROs sem fagocitose de SaPI, em 20 bezerros da raça Holandesa durante o primeiro mês de vida... .74

Gráfico 11 - Box plot da intensidade de produção de EROs por granulócitos que não realizaram fagocitose de SaPI, em 20 bezerros da raça Holandesa durante o primeiro mês de vida .75

Gráfico 12 - Box plot dos valores medianos da porcentagem de linfócitos T (CD3+) circulantes em 20 bezerros da raça Holandesa durante $\mathrm{o}$ primeiro mês de vida 
Gráfico 13- Box plot dos valores medianos da porcentagem de linfócitos $\mathrm{T}$ auxiliares (CD3+ CD4+) circulantes em 20 bezerros da raça Holandesa durante o primeiro mês de vida. .78

Gráfico 14 - Box plot dos valores medianos da porcentagem de linfócitos $\mathrm{T}$ citotóxicos $(\mathrm{CD} 3+\mathrm{CD} 8+)$ circulantes em 20 bezerros da raça Holandesa durante o primeiro mês de vida... .78

Gráfico 15- Box plot dos valores medianos da relação entre linfócitos $\mathrm{T}$ auxiliares $\mathrm{e}$ linfócitos citotóxicos (CD3+ CD4+/CD3+ CD8+) circulantes em 20 bezerros da raça Holandesa durante o primeiro mês de vida. .79 


\section{LISTA DE QUADROS}

Quadro 1 -Descrição dos reagentes, soluções e anticorpos utilizados em cada tubo para a realização das etapas de avaliação de produção de ERO, fagocitose e imunofenotipagem das amostras de sangue no citômetro de fluxo

Quadro 2 -Descrição dos anticorpos monoclonais primários e substâncias fluorescentes conjugadas utilizados em cada tubo para realização de imunofenotipagem das amostras de sangue no citômetro de fluxo.

Quadro 3-Descrição dos desenhos dos primers de cada gene alvo e do gene de referência adquiridos da empresa Applied Biosystems ${ }^{\circledR}$, utilizados 


\section{SUMÁRIO}

1 INTRODUÇÃO .............................................................................................. 23

2 REVISÃO DE LITERATURA............................................................................................... 25

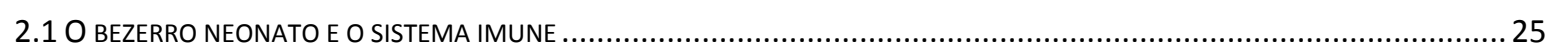

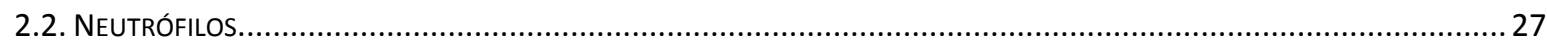

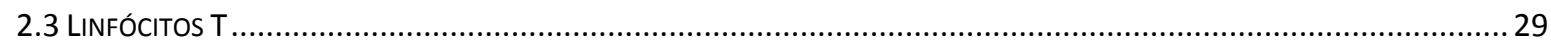

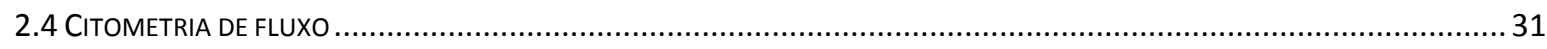

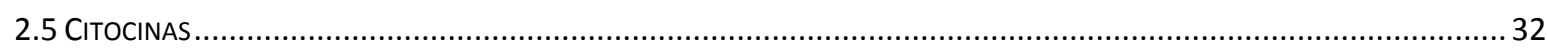

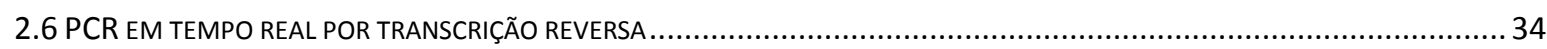

3.OBJETIVOS ....................................................................................................................................... 36

4. MATERIAL E MÉTODOS .........................................................................................................37

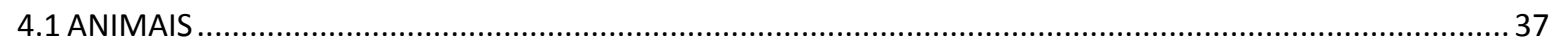

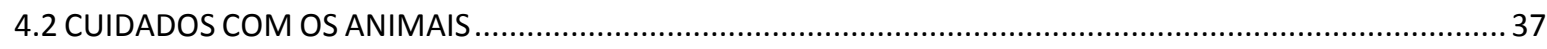

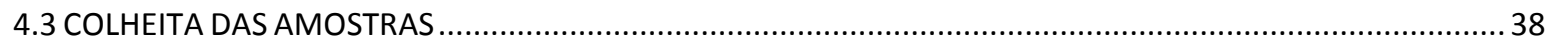

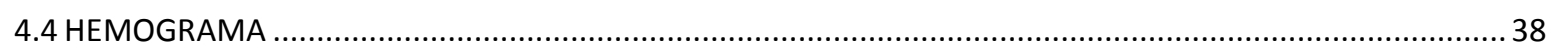

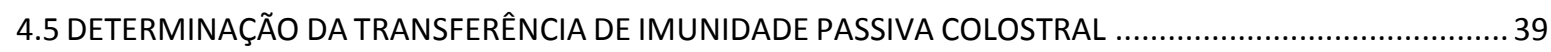

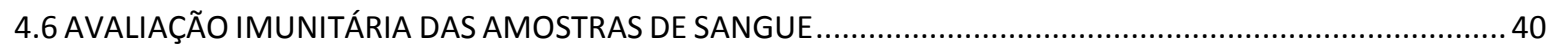

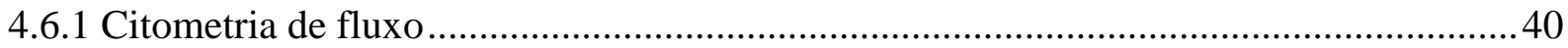

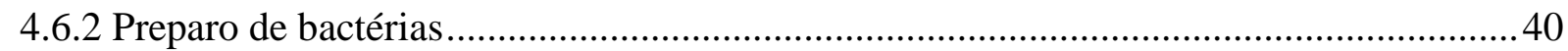

4.6.3 Avaliação da fagocitose e produção de espécies reativas de oxigênio (ERO) por citometria de fluxo...................................................................................... 42

4.6.4 Quantificação de subpopulações de linfócitos por citometria de fluxo........................... 43

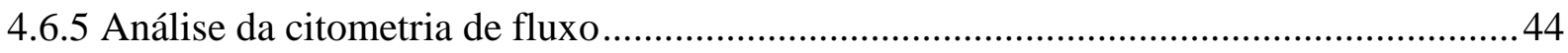

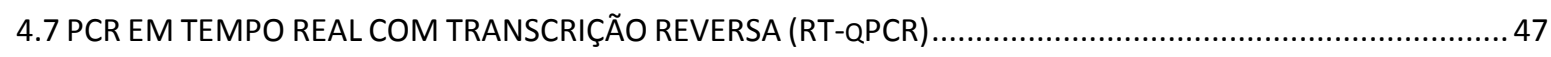

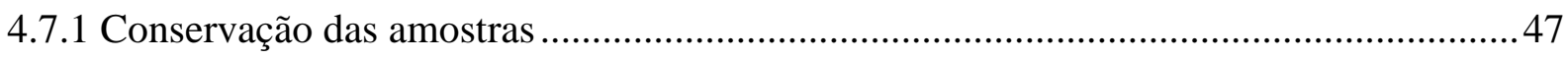

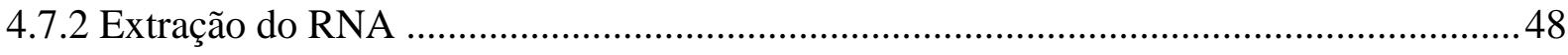

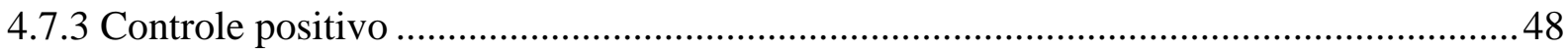

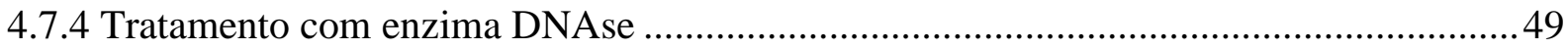

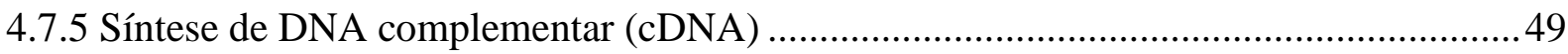

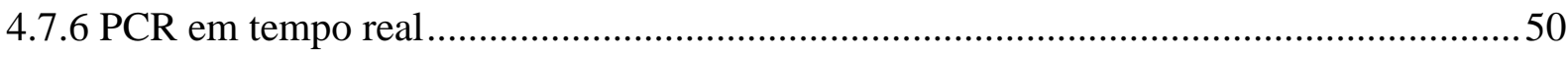

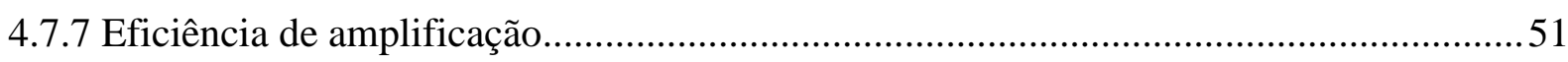




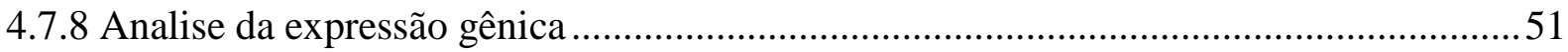

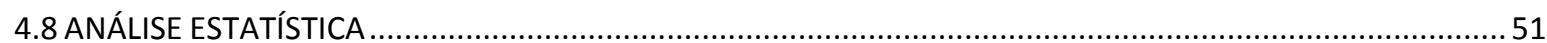

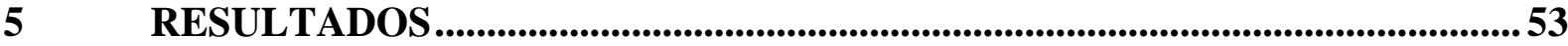

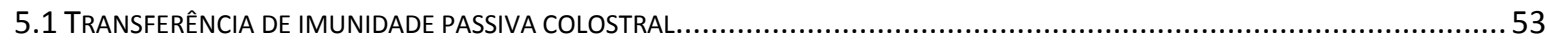

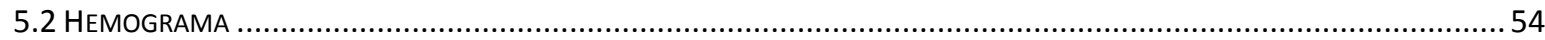

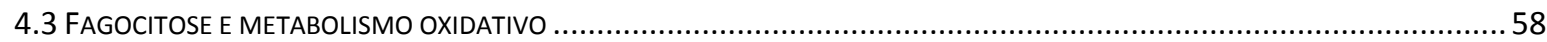

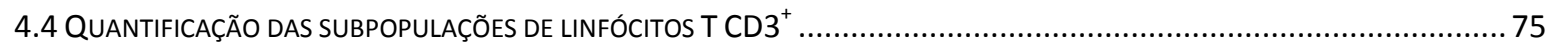

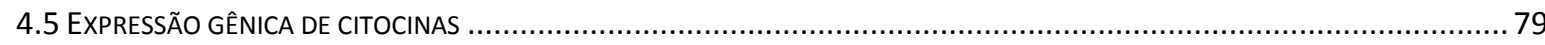

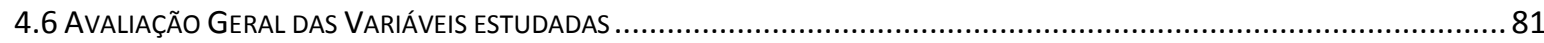

DISCUSSÃO

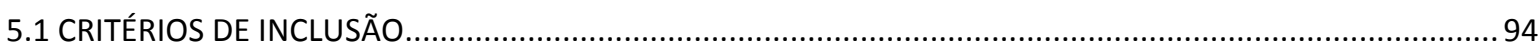

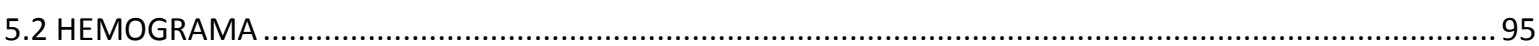

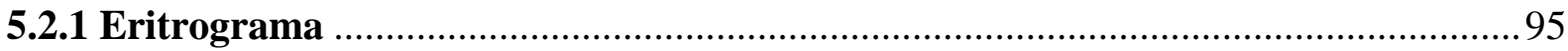

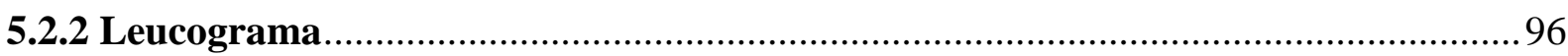

5.3 AVALIAÇÃO DOS GRANULÓCITOS: FAGOCITOSE E METABOLISMO OXIDATIVO .....................................97

5.3.1 Porcentagem e intensidade média de fluorescência de granulócitos produzindo espécies reativas de oxigênio (EROs) com e sem estímulo por Staphylococcus aureus marcados com iodeto de propídio (SaPI).

5.3.2 Porcentagem e intensidade média de fluorescência induzida pela atividade fagocítica de Staphylococcus aureus marcados com iodeto de propídio (SaPI) realizada por granulócitos com produção de espécies reativas de oxigênio (EROs) 100

5.3.3 Porcentagem e intensidade média de fluorescência da produção espécies reativas de oxigênio (EROs) em granulócitos que não estavam fagocitando Staphylococcus aureus marcados com iodeto de propídio (SaPI) ..................... 102

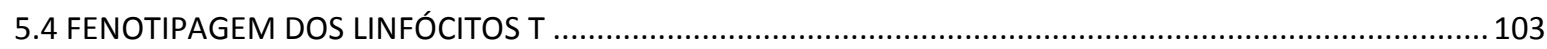

5.5. EXPRESSÃO GÊNICA DE CITOCINAS IL-14, IL-10, IL-12 E IFN-r DE LEUCÓCITOS SANGUÍNEOS ................106

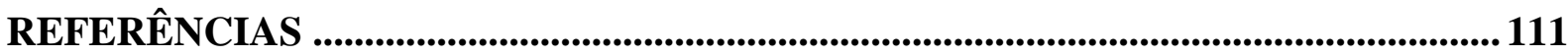




\section{INTRODUÇÃO}

A produção leiteira no Brasil é uma atividade de grande importância econômica, ocupando o quarto lugar no ranque mundial de produtores de leite e abarcando $66 \%$ do volume total de leite produzido nos países que formam o chamado MERCOSUL (Mercado Comum do Sul). Segundo dados colhidos em 2015, o Brasil contava com um rebanho de 23 milhões de cabeças de vacas em lactação; neste mesmo ano, produziu-se 34 bilhões de litros de leite, gerando um valor bruto de 28,9 bilhões de reais (EMBRAPA GADO DE LEITE, 2015).

Estima-se que nasçam cerca de 44,6 milhões de bezerros/ano no Brasil (BRASIL, 2006). Segundo Radostits e colaboradores (2002), nas duas primeiras semanas de vida os bezerros correm maior risco de morte. No Brasil, as taxas de mortalidade em bezerros podem chegar a $25 \%$, tendo como causas principais as doenças do trato respiratório e diarreias (BENESI, 1996).

As características do sistema imune do bezerro em seu período neonatal fazem com que este fique muito susceptível a doenças (BENESI, 1996; TIZARD, 2008), sendo que essa ocorrência de enfermidades diminui a rentabilidade na cadeia produtiva leiteira, seja pela morte do animal ou pelo custo do atendimento e tratamento, diminuindo também o bem-estar do neonato (RADOSTITS et al, 2002).

O sistema imune é constituído por órgãos, células e moléculas que interagem entre si combatendo microrganismos e moléculas estranhas que possam injuriar o organismo. Conceitualmente, a imunidade pode ser classificada como inata e adquirida. A imunidade inata é composta por barreiras físicas, químicas e biológicas, células especializadas (macrófagos, neutrófilos, células dendríticas e células Natural Killer) e moléculas solúveis. Possui uma resposta rápida, porém reage igualmente a todos os tipos de patógenos (CRUVINEL et al, 2010).

A imunidade adquirida é constituída principalmente pelos linfócitos e seus produtos secretados, os anticorpos, possuindo grande especificidade para diversos tipos moleculares além de capacidade de "memória", respondendo a patógenos já conhecidos com mais intensidade e rapidez (ABBAS; LICHTMAN, PILLAI, 2012).

Nos bezerros, apesar dos componentes imunitários estarem presentes ao nascimento, a ausência de estímulos antigênicos durante a gestação faz com que estes ainda não sejam totalmente funcionais (TIZARD, 2008). 
Os fatores celulares envolvidos na resposta imunitária inata apresentam, no bezerro, comportamento diferente daquele do bovino adulto. O número de neutrófilos circulantes é quatro vezes maior no bezerro recém-nascido do que no bovino adulto, no entanto a baixa concentração de opsoninas, a menor atividade do complemento e a redução da atividade bactericida de neutrófilos e fagocitária de macrófagos diminuem a eficiência do sistema imune inato (ROITT; BROSTOFF e MALE, 2003; CHASE; HURLEY; REBER, 2008).

A imunidade adquirida, durante a primeira semana pós-nascimento, também se encontra comprometida em bezerros. No recém-nascido, a quantidade de linfócitos B circulantes alcança apenas cerca de 30\% daquela verificada em adultos (BARRINGTON; PARISH, 2011), alcançando quantidades semelhantes observadas em bovinos adultos após cerca de 20 dias de vida.

Além disso, em bezerros neonatos há um deslocamento da resposta de perfil Th1 para a resposta de perfil Th2 influenciado pela ação de hormônios, como prostaglandina E2, progesterona e/ou pela ação de citocinas, como IL-4 e IL-10, provenientes da placenta (MOREIN; ABUSUGRA; BLOMQVIST, 2002). Isto faz com que ocorra uma diminuição da resposta do tipo Th1, ou seja, da imunidade celular (BARRINGTON; PARISH, 2001; CHASE; HURLEY; REBER, 2008; TIZARD, 2008; CORTESE, 2009). A polarização Th2 induz o aumento de anticorpos circulantes, porém tal resposta esta, sem memória pela ausência de estímulos anteriores (CHASE; HURLEY; REBER, 2008).

Conhecer o comportamento imunitário dos bezerros recém-nascidos auxilia a diminuir a incidência de doenças e o custo desse animal além de aumentar o bem estar. Assim sendo, nesse estudo propôs-se avaliar o padrão de resposta imunitária do neonato nos primeiros 30 dias de vida, por meio de avaliações: da atividade fagocítica e do metabolismo oxidativo de neutrófilos circulantes, da relação entre as quantidades de linfócitos T CD4+ e CD8+ circulantes e da produção de citocinas de perfil Th1 e Th2. 


\section{REVISÃO DE LITERATURA}

\subsection{O BEZERRO NEONATO E O SISTEMA IMUNE}

Repleto de características ímpares, o período neonatal, tem sido objeto de estudo de diversas pesquisas ao redor do mundo, visando uma maior compreensão das mudanças fisiológicas, de doenças e desenvolvimento de vacinas específicas com o objetivo de minorar a morbidade e mortalidade e consequentemente as perdas econômicas.

O período fetal constitui-se em seu final de diversas mudanças fisiológicas que prepararão o bezerro para a vida extrauterina. A saída do ambiente uterino, para o exterior com um ambiente totalmente contaminado faz com que os neonatos tenham premente necessidade de montar respostas imunes frente a patógenos, ao mesmo tempo em que devem regular sua homeostase orgânica e procurar por alimento (BENESI, 1993; RADOSTITS et al., 2002; BATISTA, 2011).

Todos os órgãos que participam da imunidade desenvolvem-se durante a gestação do bovino: aos 40 dias de gestação tem-se a formação do timo; subsequentemente, formam-se o baço e a medula óssea aos 55 dias, seguidos pelos linfonodos aos 60 dias e as placas de Peyer aos 175 dias (TIZARD, 2008).

Ainda que os bezerros neonatos apresentem um sistema imune morfologicamente desenvolvido, o mesmo não é capaz de modular uma adequada resposta imune, uma vez que este ainda não é funcionalmente maduro (BARRINGTON \& PARISH, 2001; CORTESE, 2009). O sistema imune de um bovino só alcançará sua total capacidade funcional na puberdade, embora a partir das duas semanas pós-nascimento já possa demonstrar componentes que são semelhantes aos encontrados em bovinos adultos (REBER et al., 2006; SCHELCHER, 2012).

Destaca-se, também, que as particularidades anatômicas e fisiológicas da placentação dos bovinos funcionam como uma barreira à transferência de imunidade durante a gestação, fazendo com que o feto bovino se desenvolva sem a influência das imunoglobulinas maternas, ficando, então, exclusivamente dependente da transferência de imunidade passiva via colostro (BARRINGTON \& PARISH, 2001; CHASE, HURLEY, REBER, 2008). 
Durante o parto, os hormônios secretados pela mãe, como a progesterona e a prostaglandina E2, podem suprimir a resposta imune do bezerro (BARRINGTON; PARISH, 2001; MOREIN; ABUSUGRA; BLOMQVIST, 2002).

Pela ausência prévia de estímulos antigênicos, pois o neonato é naive, a resposta humoral nesse momento é uma resposta primária, que por isso necessita de um maior período de latência para ocorrer e se faz com expressão de concentrações relativamente baixas de imunoglobulinas (BARRINGTON \& PARISH, 2001). O mesmo ocorre no referente à produção de citocinas e de receptores $\mathrm{T}$ (TCR), que podem se encontrar limitadas nesse período (ROITT; BROSTOFF e MALE, 2003).

Quanto às populações leucocitárias do bezerro neonato, pode-se apontar que: a quantidade de neutrófilos é maior que a quantidade de linfócitos; contudo, no decorrer das duas primeiras semanas de vida, essa proporção se inverte, apresentando o bezerro, um número maior de linfócitos, semelhantemente a um bovino adulto (BENESI, 1993).

Apesar da população leucocitária ser predominantemente neutrofílica nos primeiros dias de vida do bezerro, a resposta imune inata não se apresenta totalmente desenvolvida até o final do período gestacional, pois essas células somente são liberadas para a circulação sanguínea aos 130 dias de gestação (BARRINGTON \& PARISH, 2001). Além disso, o aumento das taxas de cortisol no feto próximo ao nascimento também contribui para um decréscimo na capacidade dessa resposta (CHASE, HURLEY, REBER, 2008).

Os linfócitos são formados a partir de células tronco e posteriormente vão sendo gradativamente liberados na corrente sanguínea, onde seguirão a outros locais para sofrer nova diferenciação, algumas células linfocitárias migram para o timo onde se diferenciarão em células T, enquanto que as células B são diferenciadas na medula óssea e nas placas de Peyer. Tais movimentações ocorrem no primeiro trimestre gestacional com ausência de estímulo antigênico (BARRINGTON \& PARISH, 2001).

A quantidade de linfócitos B no bezerro é de aproximadamente $30 \%$ daquele encontrado em um bovino adulto. Essa diferença tende a desaparecer com cerca de 20 dias de vida. No entanto, apesar dessa baixa porcentagem de linfócitos B presente no neonato bovino, em alguns dias pós-nascimento pode-se observar pequena produção de imunoglobulinas (SENOGLES, et al., 1978, BARRINGTON \& PARISH, 2001, KAMPEN, 2006).

Em relação aos linfócitos $\mathrm{T}$, os bezerros possuem uma proporção de linfócitos $\mathrm{T}$ do tipo $\gamma \delta$ maior em relação aos animais adultos. Essas células têm a capacidade de reconhecer antígenos não proteicos, funcionando como uma ponte entre a imunidade inata e adquirida (KAMPEN, et al., 2006; GARFIAS, 2011). Os linfócitos T do tipo $\alpha \beta$ (CD3+) nesse período 
representam em torno de 28 a $34 \%$ dos linfócitos totais. Em relação a esses linfócitos CD3+, estima-se que $20 \%$ do total deles sejam do tipo CD4+ (auxiliar) e 10\% do total; do tipo CD8+ (citotóxico) (CHASE, HURLEY, REBER, 2008).

Frente às particularidades do sistema imune do bezerro recém-nascido, a transferência de imunidade passiva via colostro, torna-se imprescindível para auxiliar o neonato enquanto este matura a sua imunidade (BENESI, 1992; FEITOSA, 1998).

O colostro ingerido nas primeiras 24 horas pós-nascimento, fornece ao bezerro uma grande quantidade de imunoglobulinas e outros componentes, como células (REBER, et al., 2006) e citocinas (MADUREIRA, 2011; SHECAIRA, 2013) que contribuirão para sua imunização nesse período de susceptibilidade (BENESI, 1993; BESSER; GAY, 1994; TIZARD, 2008).

O colostro, também promove ações imunomodulatórias, como a maturação de monócitos, regulação do MHC de classe I com o aumento da capacidade de reconhecer antígenos, recrutamento de células linfocíticas e diminuição do estresse fisiológico geral (CHASE, HURLEY, REBER, 2008; REBER, et al, 2008 ${ }^{\mathrm{a}}$, REBER, et al, 2008 ${ }^{\mathrm{b} \text {, }}$ ). Agindo como um suporte imunitário e imunomodulador nesse período de desenvolvimento imune dos bezerros.

\subsection{NEUTRÓFILOS}

Os neutrófilos representam a principal variedade celular formada a partir do tecido mielóide, seu núcleo é multilobulado, regularmente composto por três ou mais lóbulos unidos por filamento de cromatina. Possuem grânulos citoplasmáticos que são divididos em azurrófilos ou primários e específicos ou secundários. Os grânulos primários são lisossomos abundantes em hidrolases ácidas, mieloperoxidases e lisozima; os grânulos secundários possuem lactoferrinas e lisozimas (ROITT; BROSTOFF e MALE, 2003; TIZARD, 2008).

Tais células são de extrema importância na defesa do organismo do hospedeiro, pois atuam na imunidade celular, capturando e eliminando antígenos. Ao ocorrer injúria em um local, os neutrófilos são recrutados da circulação sanguínea por meio de substancias quimiotáticas, moléculas de adesão e citocinas. Além da expressão de receptores específicos para o reconhecimento de microrganismos ou partículas estranhas pelos neutrófilos, a 
fagocitose é favorecida pela adesão de moléculas plasmáticas, as opsoninas, na superfície do patógeno, que neutralizam sua carga eletrostática (TIZARD, 2008).

Após a fagocitose, os microrganismos são internalizados em um vacúolo denominado de fagossomo, e esse vacúolo se funde a um ou mais lisossomos originando o fagolisossomo, onde ocorrerá a destruição do patógeno por digestão enzimática e explosão respiratória (ROITT; BROSTOFF e MALE, 2003).

Ao englobar as partículas microbianas, os neutrófilos manifestam um aumento de consumo de oxigênio, chamado de explosão respiratória ou burst respiratório (BURTON, et al., 2005), produzindo grandes quantidades de ânion superóxido e peróxido de hidrogênio (BURGOS, et al.2011). Este metabolismo oxidativo é mediado pela ativação do complexo NADPH oxidase (enzima Nicotinamida Adenina Dinucleotídeo Fosfato). Com a ativação deste complexo, elétrons são liberados no citosol gerando ânions superóxido $\left(\mathrm{O}_{2}{ }^{-}\right)$. Grande parte destes ânions superóxido, pela ação da enzima superóxido dismutase convertem-se em $\mathrm{H}_{2} \mathrm{O}_{2}$ (peróxido de hidrogênio). $\mathrm{O}$ peróxido de hidrogênio, pela ação da enzima mieloperoxidase é então convertido em compostos microbicidas, como o ácido hipocloroso, principal produto deste metabolismo (TIZARD, 2008; BURGOS et al, 2011).

Nos ruminantes, diferentemente dos carnívoros, a população de neutrófilos, compõe, cerca de 20 a 35\% dos leucócitos totais (ALBERTS, et al., 2002). Em bezerros, nos primeiros dias de vida, os neutrófilos são a maior porcentagem de leucócitos (BENESI, 1993), no entanto, o funcionamento destes neutrófilos não se encontra em sua capacidade máxima até os 150 dias de idade (HAUSER, 1986). Tal fato pode ser explicado pelos baixos teores de opsoninas presentes no soro fetal, o que diminuiria a capacidade de fagocitose (ROITT; BROSTOFF e MALE, 2003). Segundo importante revisão de literatura o sistema complemento dos neonatos apresenta eficiência de 12 a 60\% quando comparada àquela do mesmo sistema em bovinos adultos (CORTESE, 2009).

Ao avaliar o metabolismo oxidativo de neutrófilos em bovinos das raças Limousin e Nelore com até quatro meses de idade, Peixoto e colaboradores (2008) verificaram que a capacidade oxidativa dos neutrófilos foi menor nos bezerros recém-nascidos. Esses autores também observaram que a capacidade oxidativa dos neutrófilos aumentou com o avançar da idade, mais precisamente a partir dos 60 dias pós-nascimento.

Doré e coautores (1990) atribuíram essa menor capacidade oxidativa ao diâmetro e área dos neutrófilos, pois comparativamente, os neutrófilos de bezerros apresentaram menores áreas e diâmetro em relação àqueles de bovinos adultos. 
Ademais, alguns autores destacam que fatores relacionados ao manejo podem influenciar a atividade funcional de neutrófilos. Segundo, Martins e colaboradores (2012), a suplementação com polivitamínicos A, D e E em bovinos da raça Holandesa com 8 a 12 meses de idade, foi capaz de promover um aumento na função de fagocitose e produção de espécies reativas de oxigênio dos neutrófilos do grupo suplementado com o polivitaminico.

Costa e colaboradores (2017) analisaram a resposta imune de bezerras que receberam colostro fresco (com células) e colostro congelado (sem células). Os resultados desta pesquisa demonstraram, que apesar de não ter havido diferença entre as porcentagens de fagocitose realizada pelos neutrófilos entre os grupos, os animais que receberam colostro com células, apresentaram neutrófilos com uma maior capacidade de produção de peróxido de hidrogênio.

\subsection{LINFÓCITOS T}

Os Linfócitos T originam-se a partir de células tronco hematopoéticas localizadas na medula óssea. O processo de maturação desses linfócitos ocorre no timo e compreende a recombinação somática, proliferação celular, expressão dos genes de receptor de células T (TCR), do complexo pentamérico CD3+ e do fenótipo CD4+ ou CD8+ de acordo com os receptores de membrana específicos adquiridos (PEREIRA; ORFAO, 2013).

O receptor das células T (TCR) é um marcador de linhagem, podendo ser do tipo $\alpha \beta$ ou $\gamma \delta$. Tal receptor é ligado ao complexo CD3 que consiste de um conjunto de cinco polipeptídeos (MESQUITA JUNIOR et al., 2010). Estima-se que a população de células T $\gamma \delta$ seja de 20 a $40 \%$ no bovino adulto e de $70 \%$ no bezerro (GARFIAS, 2011). Contudo, a medida que estes animais se tornam mais velhos, esta população se diferencia em linfócitos B e linfócitos auxiliares (KAMPEN, et al, 2006).

A função principal dos linfócitos do tipo T é a regulação de respostas imunes frente aos antígenos proteicos, atuando como células efetoras para a eliminação de patógenos intracelulares (ABBAS, LICHTMAN, PILLAI, 2012). Para que haja o reconhecimento de um antígeno pelo linfócito $\mathrm{T}$, há a necessidade da expressão de uma molécula do complexo de histocompatibilidade, o MHC, na superfície das células apresentadoras de antígenos após a fagocitose (MESQUITA JUNIOR, et al., 2010).

O MHC pode ser do tipo I ou II. Para o caso de células apresentadoras de antígenos que expressem MHC de classe II, ocorre uma ligação com receptores na superfície do 
linfócito CD4; células parasitadas, com um antígeno intracelular ou mesmo células tumorais expressam MHC de classe I, que se liga aos receptores de superfície dos linfócitos T do tipo CD8+ (TIZARD, 2008).

Dentre as células T efetoras destacam-se dois subtipos: os linfócitos auxiliares (CD4+) e os linfócitos citotóxicos (CD8+). As células T CD4+ ativam respostas imunes humorais (linfócitos B) e respostas celulares (macrófagos ou mesmo linfócitos CD8+). Enquanto que os linfócitos $\mathrm{T}$ CD8+ participam principalmente nas respostas antivirais e na atividade antitumoral (CHAPLIN, 2010).

Os Linfócitos CD4+ circulantes regulam respostas imunes. Em repouso, as células T auxiliares produzem baixos teores de citocinas. Posteriormente à estimulação por células apresentadoras de antígenos, iniciam a produção da interleucina-2 e são chamados linfócitos T Th0 (naive ou virgem). Com a progressão deste estímulo, estas células se diferenciam, polarizando-se em Th1, Th2 ou Th17 (CHAPLIN, 2010). Tal polarização é dependente das citocinas secretadas no meio (MESQUITA JUNIOR et al., 2010).

A produção de interleucina-12 por macrófagos e células Natural Killer (NK), induz a polarização de linfócitos em Th1. Tais linfócitos participam da imunidade celular, produzindo altos teores de interleucina-2 e interferon-gama que estimulam o aumento da capacidade e proliferação das células do tipo CD8+. Tal resposta é essencial para o controle de patógenos intracelulares, todavia estudos demonstram que a mesma contribui para doenças do tipo autoimune (CHAPLIN, 2010; ABBAS, LICHTMAN, PILAI, 2015).

A polarização dos linfócitos CD4+ em Th2 é induzida pela produção de IL-4 por células T Natural Killer, eosinófilos ou mastócitos. Os linfócitos polarizados para o perfil Th2 secretam citocinas IL-4, IL-5 e IL-10, favorecendo a produção de anticorpos. Atuam na resposta imune humoral, respostas alérgicas e infecções por helmintos (KIDD, 2003; CHAPLIN, 2010; MESQUITA-JUNIOR et al, 2010).

Também conhecidos como linfócitos citotóxicos, os linfócitos CD8+, exercem sua ação sobre células tumorais e células parasitadas com antígenos intracelulares (TIZARD, 2008). As células citotóxicas possuem grânulos citoplasmáticos com substâncias tais como a perforima e a granzina. Por um processo de exocitose, o linfócito CD8+ se une à célula alvo e, com a transferência desses grânulos, lisam a célula (MESQUITA JUNIOR, et al., 2010).

Kampen e colaboradores (2006) avaliaram as subpopulações de linfócitos T em bezerros até os seis meses de idade, constatando que as subpopulações de células $\mathrm{T}$ estão presentes no sangue periférico de bezerros em taxas semelhantes àqueles de bovinos adultos. 
No entanto, Ayoub e Yang em 1996 para estudarem as variações das subpopulações de linfócitos no sangue de bovinos da raça Holandesa, de acordo com a evolução da idade, acompanharam quatro bezerros desde 1 a 2 meses de idade até os dois anos. Observaram que aos 6 meses de idade, 20 a 35\% dos linfócitos circulantes eram do tipo CD4+, enquanto que 10 a $15 \%$ eram linfócitos do tipo CD8+. Tais porcentagens sofreram um decréscimo, apresentando-se com $15 \%$ e 5-7\%, respectivamente aos 8 meses. A proporção de linfócitos CD4+/CD8+ também evidenciou variações, sendo em torno de 2,38 até os seis meses, decrescendo para 1,81 após os oito meses. Os autores atribuíram tais mudanças ao início da puberdade destes animais, por consequência do aumento da produção de hormônios esteroidais que podem induzir uma involução tímica transitória.

\subsection{CITOMETRIA DE FLUXO}

A citometria de fluxo é um método que avalia parâmetros morfológicos e funcionais de células em suspensão. Essa avaliação ocorre por meio de dispersão da luz e emissão de fluorescência de substâncias aderidas a célula (tanto em sua superfície como em seu interior) e possibilita a análise individual da célula e seu agrupamento em populações de acordo com os parâmetros mensurados (BERTHO e FERRAZ, 2013).

A técnica de citometria de fluxo tem sido cada vez mais empregada na avaliação das populações leucocitárias e atividade celular desde sua disponibilização comercial na década de 70. O desenvolvimento da técnica de produção de anticorpos monoclonais, que rendeu um prêmio Nobel a Köhler, Milstein e Niels Jerne, possibilitou o acoplamento de substâncias fluorescentes a anticorpos extremamente específicos contra epítopos intra- e extracelulares (BERTHO; FERRAZ 2013).

Tal técnica tem sido vastamente empregada nas investigações de ordem imunológica principalmente em humanos, para a identificação de subtipos celulares, sua fisiologia e compreensão de seu funcionamento (BERTHO e FERRAZ, 2013).

$\mathrm{Na}$ medicina veterinária, sua utilização vem sendo cada vez mais difundida nos mais diversos campos. A investigação das populações celulares relacionadas ao sistema imune e sua atividade em bovinos por meio da técnica de ciometria de fluxo tem sido realizada por diversos pesquisadores visando conhecer aspectos celulares como características e quantidade 
de populações, suas funções, deficiências funcionais, entre outros (KAMPEN, et al., 2006; AZEDO, 2007; BATISTA, 2011; BERTAGNON, 2015; GOMES, 2016).

\subsection{CITOCINAS}

As citocinas são proteínas que atuam como moléculas de sinalização extracelulares em diversos processos imunes inatos ou específicos. Essas moléculas atuam de maneira autócrina ou parácrina sendo sua produção um evento limitado e fugaz. Podem ser secretadas por vários tipos celulares, principalmente por macrófagos e linfócitos, sendo capazes de atuar sobre diversos tipos celulares, característica essa denominada pleiotropismo (ROITT; BROSTOFF e MALE, 2003; TIZARD, 2008; ABBAS; LICHTMAN; PILLAI, 2015).

Dentre as variadas funções das citocinas, destaca-se a capacidade destas em influenciar a polarização das células $\mathrm{T}$ naive ou Th0 em células Th1 ou Th2. As subpopulações de células Th1 e Th2 têm seu desenvolvimento a partir de um mesmo tipo celular, o linfócito T CD4+ Essa diferenciação é dependente do estimulo recebido pelo linfócito Th0, ou seja, das interações entre células, do microambiente e da produção de uma ou mais citocinas em resposta a determinado antígeno. O perfil imunitário do tipo Th1 possui uma resposta predominantemente celular, enquanto que o perfil Th2 desencadeia resposta predominantemente humoral (KIDD, 2003; ABBAS; LICHTMAN; PILLAI, 2015).

As células T naive são diferenciadas em Th1 a partir de um estímulo causado pela presença de interleucina-12, produzida por células natural killers (NK) em resposta ao reconhecimento de um antígeno no organismo. Após essa diferenciação, o linfócito CD4+ Th1 secretará interferon-gama, citocina esta que induzirá a ativação de macrófagos para a fagocitose e produção de espécies reativas de oxigênio (ERO) (ROMAGNANI, 1992).

A polarização Th2 ocorre quando há secreção da citocina IL-4. Uma vez polarizado no perfil Th2, o linfócito secreta interleucinas 4 e 5 além da interleucina-10 que tem um papel supressor, inibindo a diferenciação dos linfócitos naive em linfócitos Th1. As interleucinas 4 e 5 irão estimular mastócitos, eosinófilos e linfócitos $\mathrm{B}$, linfócitos estes que produzirão anticorpos, principalmente do tipo IgE, modulando a resposta imunitária em resposta humoral e contra alérgenos (ROMAGNANI, 1992; KIDD, 2003; TIZARD, 2008).

A Interleucina-4 pode ser produzida por células Th2 ativadas, basófilos e mastócitos, atuando sobre linfócitos B e T, macrófagos e mastócitos. Atua conjuntamente com a 
interleucina-5, aumentando a resposta humoral e a produção de imunoglobulina $\mathrm{E}$ frente a parasitas (KIDD, 2003).

Estudos demonstram que durante uma gestação saudável em algumas espécies (ratos, humanos, murinos) há uma predominância de perfil Th2. O aumento de citocinas Th1 como TNF- $\alpha$ e IFN- $\gamma$ promove a morte de células trofloblásticas, a inibição da implantação de embriões de ratos e a proliferação de células trofloblásticas em humanos (RAGHUPATHY et al., 1999). Sabe-se que alguns hormônios secretados pela placenta durante a gestação, como a prostaglandina E2 e a progesterona contribuem para uma polarização de perfil Th2 e supressão de diferenciação de células Th1. A progesterona induz uma diminuição da IL-12 e um aumento da IL-10. Essa modulação imunitária garante que o feto não seja tratado como um antígeno pelo organismo materno (MOREIN; ABUSUGRA; BLOMQVIST, 2002).

Assim, a Interleucina-10 é uma citocina denominada anti-inflamatória ou imunossupressora. Atua limitando as respostas imunes, impedindo uma reação exagerada, ação fundamental para proteção de dano tecidual numa fase inflamatória aguda do hospedeiro (ROJAS et al., 2017). Regula especialmente as atividades celulares de células T e macrófagos, inibindo a síntese de citocinas de perfil Th1 (IL-1. IFN- $\gamma$ e TNF- $\alpha$ ); em macrófagos ativados suprime a secreção de citocinas IL-1, IL-6 e TNF- $\alpha$ e também a produção de radicais livres de oxigênio (KIDD, 2003; ALMERIA et al., 2012).

A Interleucina-12 (IL-12) é produzida por todas as células apresentadoras de antígenos, onde se incluem também monócitos e macrófagos. Esta citocina estimula a diferenciação das células Th1, fazendo com que ocorra a produção de Interferon-gama e de Interleucina-2 por essas células, e promovendo a proliferação e ativação de células citotóxicas. Entre suas ações também destaca-se a supressão da síntese de IL-4, IL-10 e de imunogloblulinas, especialmente do tipo E (KIDD, 2003; ABBAS; LICHTMAN; PILLAI, 2012).

A citocina Interferon-gama (IFN- $\gamma$ ) é produzida principalmente por Linfócitos CD4+e CD8+ após a ativação por células Natural Killer (NK) (ABBAS; LICHTMAN; PILLAI, 2012). Por ser um ativador potente dos fagócitos mononucleares, contribui indiretamente para a produção de espécies reativas de oxigênio (ERO) pelos macrófagos, potencializando a inflamação e a atividade antimicrobiana. Concomitantemente, inibe as reações mediadas por IgE e eosinófilos. Além disso, promove a diferenciação das células CD4+ em células Th1 e inibe a diferenciação dessas mesmas células em células do perfil Th2 (BANNERMAN, 2009). Alguns trabalhos foram encontrados demonstrando o balanço Th1/Th2 em bovinos, no entanto, esse balanço foi averiguado frente a um desafio vacinal ou por doença (MENA et al., 
2002; INGALE et al., 2008; ALMERIA et al., 2012; BERTAGNON, 2014; BATISTA et al., 2015), contudo, observou-se a carência de trabalhos que demonstrassem o perfil imunitário Th1/Th2 em bezerros neonatos em condições imunitárias basais.

\subsection{PCR EM TEMPO REAL POR TRANSCRIÇÃO REVERSA}

A Reação de Polimerase em Cadeia (PCR) foi desenvolvida na década de 80, por Kary Mullis, que recebeu o prêmio Nobel por seu desenvolvimento em 1994. Tal processo permitiu que o DNA pudesse ser multiplicado artificialmente por meio de repetições de ciclos de duplicação catalisados pela DNA polimerase, sendo o processo totalmente realizado ex vivo (VALASEK; REPA, 2005).

Posteriormente, em 1993, Higuchi e coautores, descreveram a técnica da PCR em tempo real ou PCR quantitativa. Onde um sistema com câmera de vídeo fora acoplado de maneira que pudessem monitorar os ciclos da PCR, permitindo a detecção do aumento da fluorescência ao longo do processo.

A PCR em tempo real por transcrição reversa é constituída por três passos: transcrição reversa de RNA em cDNA (DNA complementar), amplificação do cDNA pela reação de polimerase em cadeia e a quantificação dos produtos da amplificação em tempo real. Tal ensaio é assentado na aferição do sinal de fluorescência, que é proporcional à quantidade de DNA produzido a cada ciclo de PCR (BUSTIN, et al, 2006).

O chamado ciclo limiar, ou threshold cycle $(\mathrm{Ct})$, é definido como o ciclo da reação de PCR no qual o sinal fluorescente do corante sinalizador atravessa uma linha arbitrária denominado limiar (SCHMITTGEN; LIVAK, 2008). Quanto mais moléculas do alvo estiverem presentes no ensaio, mais rapidamente ocorrerá a amplificação e, por conseguinte, menor será o ciclo limiar (KUBISTA et al., 2006).

São descritas duas técnicas de quantificação dos genes, as quantificações absoluta e relativa. Enquanto a primeira é utilizada para identificação de vírus, células tumorais, a segunda é empregada para mensurar diferenças das taxas de expressão de RNA mensageiro, podendo ser útil na investigação de mudanças fisiológicas do organismo (PFFAFFL, 2001; BUSTIN, 2005).

A técnica da PCR em tempo real vem sendo cada vez mais difundida na medicina veterinária, em pesquisas de vírus, parasitas, imunidade, genética e outras (LEUTENEGGER 
et al., 2000; KONNAI et al., 2003; YAMANAKA, et al., 2003; GRELL, et al., 2005; OHTSUKA et al., 2014; ONO; TANIWAKI; BRANDÃO, 2017) 


\section{OBJETIVOS}

O presente estudo teve por objetivo a avaliação do padrão de resposta imunitária do neonato nos primeiros 30 dias de vida, tendo como objetivos específicos:

1- A avaliação da atividade fagocítica e do metabolismo oxidativo de granulócitos circulantes,

2- A relação entre as quantidades de linfócitos T CD4+ e CD8+ circulantes

3- E a avaliação da produção de citocinas de perfil Th1 e Th2. 


\section{MATERIAL E MÉTODOS}

A execução deste experimento foi aprovada pela Comissão de Ética no Uso de Animais da Faculdade de Medicina Veterinária e Zootecnia da Universidade de São Paulo, e sua autorização registrada em 22/01/2014 em documento CEUA n 2372210114.

\subsection{ANIMAIS}

Utilizou-se na execução deste experimento, 20 bezerros da raça Holandesa Preta e Branca, machos, nascidos de parto eutócico, provenientes de novilhas ou vacas sadias, oriundos de uma propriedade leiteira do Estado de São Paulo, situada a $240 \mathrm{~km}$ de distância da capital.

Nas primeiras seis horas pós-nascimento, os bezerros receberam colostro proveniente de um banco de colostro da propriedade de origem e ainda no primeiro dia de vida foram transportados para a Faculdade de Medicina Veterinária e Zootecnia da Universidade de São Paulo em São Paulo/SP, onde foram alocados no Biotério da Clínica de Bovinos e Pequenos Ruminantes (CBPR), em baias com capacidade para até dois animais, até os 30 dias de vida.

\subsection{CUIDADOS COM OS ANIMAIS}

Os animais receberam colostro oriundo de um banco de colostro, estabelecidos exclusivamente para o experimento, nos primeiros três dias de vida a fim de garantir adequada transferência de imunidade passiva. Posteriormente, receberam sucedâneo de leite integral em pó reconstituído em água, em volume equivalente a 10\% de seu peso vivo, dividido em duas alimentações diárias e fornecido em mamadeira até os 30 dias.

A partir da segunda semana de vida dos bezerros, também era oferecido água "ad libitum", feno e ração no cocho, visando o estímulo de desenvolvimento dos pré-estômagos. 
A antissepsia do umbigo foi realizada com solução de iodo a 5\%, aplicada duas vezes ao dia até os três dias de vida. Os animais também foram submetidos a avaliações sequenciais, por meio de exames físico geral (DIRKSEN, 1993; FEITOSA; BENESI, 2014) e laboratorial, nos momentos do nascimento, aos três e cinco dias de idade, e a cada cinco dias até que se completasse 30 dias de vida.

\subsection{COLHEITA DAS AMOSTRAS}

Coletou-se de cada animal, por venopunção jugular com uso de agulha $25 \mathrm{~mm}$ x 8 mm, e antissepsia prévia com álcool a $70 \%$, utilizando-se sistema a vácuo. As amostras de sangue foram colhidas em tubos siliconizados com heparina ou com cácido etilenodiamino tetra-acético (EDTA) tripotássico na proporção de $1,5 \mathrm{mg} / \mathrm{mL}$ de sangue nos tempos programados a saber: dias $1^{\circ}, 3^{\circ}, 5^{\circ}, 10^{\circ}, 15^{\circ}, 20^{\circ}, 25^{\circ}$ e $30^{\circ}$ pós-nascimento.

Para a avaliação da transferência da imunidade passiva colostral, coletou-se amostras de sangue também por punção da veia jugular, utilizando-se frascos com sistema a vácuo, para obtenção de soro após 24 horas da ingestão de colostro pelo bezerro.

Todas as amostras foram identificadas com o nome do animal e data de coleta sendo imediatamente transportadas, sob refrigeração, até o laboratório de Pesquisa do Departamento de Clínica Médica da FMVZ/USP.

\subsection{HEMOGRAMA}

As contagens totais e diferencias de leucócitos e de hemácias, as avaliações das taxas de hemoglobina e do volume globular e o cálculo dos índices hematimétricos foram realizados em contador eletrônico de partículas ${ }^{1}$.

\footnotetext{
${ }^{1}$ Mindray® BC- 2800 Vet; Mindray Medical International Limited, São Paulo, SP.
} 


\subsection{DETERMINAÇÃO DA TRANSFERÊNCIA DE IMUNIDADE PASSIVA COLOSTRAL}

A avaliação da qualidade da transferência de imunidade passiva dos 20 bezerros incluídos no estudo foi realizada a partir de amostras de sangue de animais com idades entre 24 e 48 horas de vida, nos quais mensurou-se as concentrações de substâncias com alta correlação com os teores séricos de imunoglobulinas, a saber: proteína sérica total (PT), globulinas séricas e a atividade enzimática da Gamaglutamiltransferase (GGT).

Após a colheita de sangue em tubos sem anticoagulante, aguardou-se a retração do coágulo e procedeu-se a centrifugação dos tubos em centrífuga comum a 1000 x $g$, por 15 minutos. As amostras do soro obtidas foram aliquotadas em pequenos volumes e armazenadas em freezer a $-20^{\circ} \mathrm{C}$ para posterior avaliação.

Determinou-se a proteína sérica total (PT) por refratometria. Após a calibragem do refratômetro com água destilada, este foi limpo e seco. Pipetou-se $0,5 \mathrm{~mL}$ de soro sanguíneo, colocando-se este volume sobre a superfície óptica para cobrir a metade dessa área. Em seguida, fechando a tampa do refratômetro, procedeu-se a leitura do valor de proteína total, fornecido pela linha que separa a zona escura da clara. Há diversidade de valores apresentados na literatura como indicadores de falha de transferência de imunidade passiva (FTIP), adotando-se para a presente pesquisa as concentrações menores que 5,0 g/dL como indicativas desta falha (SMITH, 2005).

Foi mensurada a taxa de albumina sérica em analisador automático bioquímico ${ }^{2}$, por método colorimétrico (verde de bromocresol), e, por meio da diferença desta com aquela da PT, foi calculada a concentração de globulinas. Considerou-se que valores séricos de globulina inferiores a 2,25 g/dL indicaram FTIP (HILL, 2010).

Utilizou-se o método cinético colorimétrico para a determinação da atividade sérica da GGT, recomendado pela International Federation of Clinical Chemistry (IFCC), fazendo uso de kit comercial, segundo técnica modificada de Szasz et al. (1969), em analisador bioquímico automático, em comprimento de onda de $405 \mathrm{~nm}$, considerando valores inferiores a 50 UI/L, indicativos de FTIP(RADOSTITS et al. 2002).

\footnotetext{
${ }^{2}$ Randox® RX Daytona.
} 


\subsection{AVALIAÇÃO IMUNITÁRIA DAS AMOSTRAS DE SANGUE}

\subsubsection{Citometria de fluxo}

As avaliações para quantificação das subpopulações leucocitárias, da produção intracelular de ERO e de fagocitose por leucócitos sanguíneos foram realizadas em citômetro de fluxo FACSCalibur® ${ }^{3}$ conforme as técnicas descritas por Azedo (2007).

De cada amostra de sangue total colhida, foram utilizadas alíquotas para a realização dos ensaios de produção de espécies reativas de oxigênio (ERO) e de fagocitose, com evidenciação de atividade própria de neutrófilos por meio da utilização de anticorpos monoclonais específicos contra marcadores de superfície presentes nestas células. Simultaneamente, foram preparadas alíquotas para quantificação das subpopulações de linfócitos T. Para a quantificação das subpopulações leucocitárias, verificou-se a porcentagem de células com fluorescências específicas de cada anticorpo monoclonal secundário.

Para a observação da fagocitose e produção de ERO foi necessária a realização da marcação de bactérias da espécie Staphylococcus aureus com o marcador nuclear Iodeto de propídio. O protocolo utilizado foi descrito no tópico a seguir.

\subsubsection{Preparo de bactérias}

Utilizou-se para este experimento a espécie bacteriana Staphylococcus aureus (ATCC 25923), cedida gentilmente pelo Dr. Igor Mímica, chefe de desenvolvimento da Empresa Probac do Brasil.

As bactérias foram transportadas em meio BHI (Brain Heart Infusion) líquido até a Faculdade de Medicina Veterinária e Zootecnia da Universidade de São Paulo, onde foram incubadas em estufa a $37^{\circ} \mathrm{C}$ por 18 horas. Após esse período foram transferidos aproximadamente $60 \mu \mathrm{L}$ da solução para cada placa de Petri contendo meio Ágar TSA. Ao

\footnotetext{
${ }^{3}$ Becton Dickinson Immunocytometry System ${ }^{\mathrm{TM}}$, San Diego, CA.
} 
todo, semeou-se 36 placas. As quais foram novamente incubadas em estufa a $37{ }^{\circ} \mathrm{C}$ por 18 horas. Posteriormente, a colheita das colônias foi realizada utilizando-se um swab estéril, e depositando-as em tubos cônicos contendo $10 \mathrm{~mL}$ de solução estéril de HBSS (Hank's Buffered Salt Solution). Estes tubos foram em seguida centrifugados a 1.100 x $g$ durante 10 minutos. Após a centrifugação, os tubos foram acomodados em banho Maria a $60^{\circ} \mathrm{C}$ durante 60 minutos, para a inativação das bactérias. Uma alíquota dessa suspensão bacteriana foi retirada e novamente semeada em placa de Petri contendo Ágar Sangue e incubada por 8 horas em estufa a $37^{\circ} \mathrm{C}$, para se certificar de que o período e temperatura utilizados no banho Maria haviam sido suficientes para a inativação das bactérias. Durante esse período, as demais suspensões bacterianas foram acondicionadas sob refrigeração a $4^{\circ} \mathrm{C}$. Em seguida, os tubos contendo as suspensões foram centrifugados novamente como descrito anteriormente e o sobrenadante desprezado, o botão de bactérias foi dissolvido e novamente ressuspendido com 10 mL de solução HBSS.

Para o ajuste da concentração de bactérias $\left(24 \times 10^{8} / \mathrm{mL}\right)$, a suspensão foi diluída na solução HBSS até chegar à escala 08 de Mc Farland. Para tanto, foram necessários $60 \mathrm{~mL}$ de solução HBSS para 10 mL de solução bacteriana.

Para a marcação dos S. aureus utilizou-se o marcador nuclear Iodeto de Propídio ${ }^{4}$. O marcador foi preparado diluindo-se $200 \mu \mathrm{L}$ de Iodeto de Propídio em $200 \mathrm{~mL}$ da solução de HBSS. Em seguida, diluiu-se a suspensão bacteriana nesta solução de Iodeto de Propídio na proporção de 1:1. Essa mistura foi mantida sob agitação contínua durante 24 horas, sob refrigeração de $4^{\circ}$ e abrigo da luz. Findado este período, os tubos foram centrifugados a 16.000 x $g$ durante 30 segundos, desprezado o sobrenadante e ressuspendido o botão com solução de HBSS. Essa solução foi aliquotada e armazenada em microtubos com capacidade para $2 \mathrm{~mL}$ e acondicionados em freezer a menos $20^{\circ} \mathrm{C}$ até o momento do uso.

\footnotetext{
${ }^{4}$ Sigma ${ }^{\circledR}$, St. Louis, MO; no. cat. P4170.
} 


\subsubsection{Avaliação da fagocitose e produção de espécies reativas de oxigênio (ERO) por citometria de fluxo}

Para cada amostra coletada, foram depositados $25 \mu \mathrm{L}$ de sangue em tubos de polipropileno específicos para citometria previamente identificados (quadro 1) e contendo 1 mL de solução salina fosfatada (PBS 10X) diluída em agua MiliQ (1:10). Em um destes tubos contendo $25 \mu \mathrm{L}$ de sangue diluídos em $1 \mathrm{~mL}$ de PBS, adicionou-se $1 \mu \mathrm{L}$ de preparação de anticorpo monoclonal anti-granulócito bovino ${ }^{5}$ para marcação da população de neutrófilos (quadro 1), e após a homogeneização da solução, incubou-se a $4^{\circ} \mathrm{C}$, por 30 minutos. Seguidamente este tubo foi centrifugado ${ }^{6}$, o sobrenadante desprezado, o botão celular ressuspendido em PBS e o anticorpo secundário acrescentado (anti-IgM de camundongo conjugado com $\mathrm{PerCP}^{7}$ ).

Para a avaliação da produção de ERO pelos neutrófilos sem estímulo ex vivo (produção basal), adicionou-se a um dos tubos de cada amostra $15 \mu \mathrm{g}$ de Diacetato de 2,7Diclorodihidrofluoresceína (DCFH-DA) ${ }^{8}$. Por sua vez, para a avaliação da produção de ERO após estímulo ex vivo pela fagocitose de $S$. aureus, e da atividade fagocítica dos neutrófilos, adicionou-se a um dos tubos de cada amostra $15 \mu \mathrm{g}$ de DCFH-DA e $100 \mu \mathrm{L}$ de $S$. aureus conjugado com iodeto de propídio (SaPI). Os tubos foram, então, incubados em banho-maria, a uma temperatura de $37^{\circ} \mathrm{C}$, sob agitação ligeira por 30 minutos. Após esse período, acrescentou-se $2 \mathrm{~mL}$ de solução de EDTA em uma concentração de $3 \mathrm{mM}$, visando o bloqueio das reações e, a seguir, foram então centrifugados ${ }^{6}$.

Para a lise dos eritrócitos, após desprezar-se o sobrenadante, foi colocado $2 \mathrm{~mL}$ de $\mathrm{NaCl}$ a $0,2 \%$ e, esperados 30 segundos, $2 \mathrm{~mL}$ de $\mathrm{NaCl}$ a 1,6\%, para a recomposição da isotonicidade. Repetiu-se a lise de eritrócitos e, após desprezar-se o sobrenadante mais uma vez, em cada tubo foi adicionado $500 \mu \mathrm{L}$ de PBS.

\footnotetext{
${ }^{5}$ Mouse IgM anti-Bovine Granulocyte [clone CH138A] - Kingfisher Biotech®, Saint Paul, MN; no. cat. WS0608B-100.

${ }^{6}$ Durante 10 minutos, a $280 \mathrm{x} \mathrm{g}$, em centrífuga refrigerada a $4^{\circ} \mathrm{C}$

${ }^{7}$ Goat anti-Mouse IgM-PerCP - Santa Cruz Biotechnology®, Dallas, TX; no. cat. sc-45094

${ }^{8}$ Carboxy-DCFDA [5-and-6-Carboxy-2',7'-Dichlorofluorescein Diacetate] - Molecular Probes $®$, Eugene OR; no. cat. C369.
} 
Quadro 1 - Descrição dos reagentes, soluções e anticorpos utilizados em cada tubo para a realização das etapas de avaliação de produção de ERO, fagocitose e imunofenotipagem das amostras de sangue no citômetro de fluxo.

\begin{tabular}{|lll|}
\hline Identificação & Conteúdo & Etapa \\
\hline Tubo A & Suspensão celular & Calibração \\
\hline Tubo B & DCFH & Ensaio \\
\hline Tubo C & DCFH+ SaPI & Ensaio \\
\hline Tubo D & SaPI & Calibração \\
\hline Tubo E & CH138 + PerCP & Calibração \\
\hline
\end{tabular}

Fonte: Shecaira, 2017.

\subsubsection{Quantificação de subpopulações de linfócitos por citometria de fluxo}

De cada amostra de sangue total coletada nos momentos de estudo, alíquotas de $25 \mu \mathrm{L}$ foram utilizadas para a avaliação da expressão de marcadores celulares de linfócitos, por citometria de fluxo. As alíquotas foram transferidas para tubos de polipropileno para citometria contendo $1 \mathrm{~mL}$ de PBS diluído com água MiliQ na proporção de 1:10. Nos tubos, foram adicionados $1 \mu \mathrm{L}$ de anticorpo monoclonal primário (anti-CD3 bovino ${ }^{9}$, anti-CD8 bovino $^{10}$ e anti-CD4 bovino ${ }^{11}$.) Os tubos foram, então, incubados a $4^{\circ} \mathrm{C}$, por 30 minutos. Após a incubação, realizou-se a centrifugação durante 10 minutos, a 280 x g, em centrífuga refrigerada a $4^{\circ} \mathrm{C}$. Posteriormente, desprezou-se o sobrenadante e o botão celular foi ressuspendido em $1 \mathrm{~mL}$ de PBS a cada tubo.

Prontamente foram adicionados aos tubos $1 \mu \mathrm{L}$ de anticorpo monoclonal secundário (anti-IgG1 de camundongo conjugado com FITC ${ }^{12}$, anti-IgG2a de camundongo conjugado com $\mathrm{PE}^{13}$ e anti-IgM de camundongo conjugado com $\mathrm{PerCP}^{14}$ ). Os tubos foram, então,

\footnotetext{
${ }^{9}$ Mouse IgG1 anti-Bovine CD3 [clone MM1A] - Kingfisher Biotech®, Saint Paul, MN; no. cat. WS0561B-100.

${ }^{10}$ Mouse IgG2a anti-Bovine CD8 alpha [clone 7C2B] - Kingfisher Biotech®, Saint Paul, MN; no. cat. WS0502B-100.

${ }^{11}$ Mouse IgM anti-Bovine CD4 [clone GC50A] - Kingfisher Biotech®, Saint Paul, MN; no. cat. WS0563B-100.

${ }^{12}$ Goat anti-Mouse IgG-FITC - Santa Cruz Biotechnology®, Dallas, TX; no. cat. sc-2078

${ }^{13}$ Goat anti-Mouse IgG2a-PE - Santa Cruz Biotechnology®, Dallas, TX; no. cat. sc-3765
} 
incubados a $4^{\circ} \mathrm{C}$, por 30 minutos. Após a incubação, realizou-se a centrifugação durante 10 minutos, a $280 \mathrm{x} \mathrm{g}$, em centrífuga refrigerada a $4^{\circ} \mathrm{C}$.

Para a lise dos eritrócitos, após desprezar-se o sobrenadante, foi colocado $2 \mathrm{~mL}$ de $\mathrm{NaCl}$ a $0,2 \%$ e, esperados 30 segundos, adicionalmente colocou-se $2 \mathrm{~mL}$ de $\mathrm{NaCl}$ a 1,6\%, para a recomposição da isotonicidade. Repetiu-se a lise de eritrócitos e, após desprezar-se o sobrenadante mais uma vez, adicionou-se em cada tubo $500 \mu \mathrm{L}$ de PBS.

\subsubsection{Análise da citometria de fluxo}

Para as avaliações qualitativas e quantitativas, cinquenta mil leucócitos de cada amostra foram analisados em citômetro de fluxo. Os dados assim obtidos foram avaliados utilizando-se do programa FlowJo ${ }^{15}$. Para a quantificação das subpopulações linfocitárias, verificou-se a porcentagem de células com fluorescências específicas de cada anticorpo monoclonal secundário (Quadro 2). Leucócitos $\mathrm{CD}^{+}$e $\mathrm{CD}^{+}$foram considerados linfócitos $\mathrm{T}$ auxiliares e leucócitos $\mathrm{CD}^{+}$e $\mathrm{CD}^{+}$foram considerados linfócitos T citotóxicos.

\footnotetext{
${ }^{14}$ Goat anti-Mouse IgM-PerCP - Santa Cruz Biotechnology®, Dallas, TX; no. cat. sc-45094

${ }^{15}$ Tree Star ${ }^{\mathrm{TM}}$, Inc., Ashland, OR.
} 
Quadro 2- Descrição dos anticorpos monoclonais primários e substâncias fluorescentes conjugadas utilizados em cada tubo para realização de imunofenotipagem das amostras de sangue no citômetro de fluxo.

\begin{tabular}{|lll|}
\hline Identificação & Conteúdo & Etapa \\
\hline Tubo A & Suspensão celular & Calibração \\
\hline Tubo F & Anti-CD3-FITC + Anti-CD4- & Ensaio \\
& PerCP + Anti-CD8-PE & \\
\hline Tubo H & Anti-CD3-FITC & Calibração \\
\hline Tubo I & Anti-CD8-PE & Calibração \\
\hline
\end{tabular}

Fonte: Shecaira, 2017.

Avaliou-se a intensidade de produção de EROs e a intensidade de fagocitose de SaPI, por meio da intensidade de fluorescência, respectivamente, da DCF e do iodeto de propídio, expressas em valores aleatórios. Tal avaliação foi realizada nas células contidas no gate (Figura 1) correspondente aos leucócitos sanguíneos com características de tamanho (FSC) e granulosidade (SSC) condizentes com as esperadas para granulócitos, confirmadas pela alta porcentagem de células (Figura 2) contendo marcador de superfície específico $\left(\mathrm{CH} 138^{+}\right)$. 
Figura 1 Citograma demonstrando o gate correspondente aos leucócitos sanguíneos com características de tamanho (FSC) e granulosidade (SSC) utilizado para a avaliação dos granulócitos das amostras de sangue por citometria de fluxo

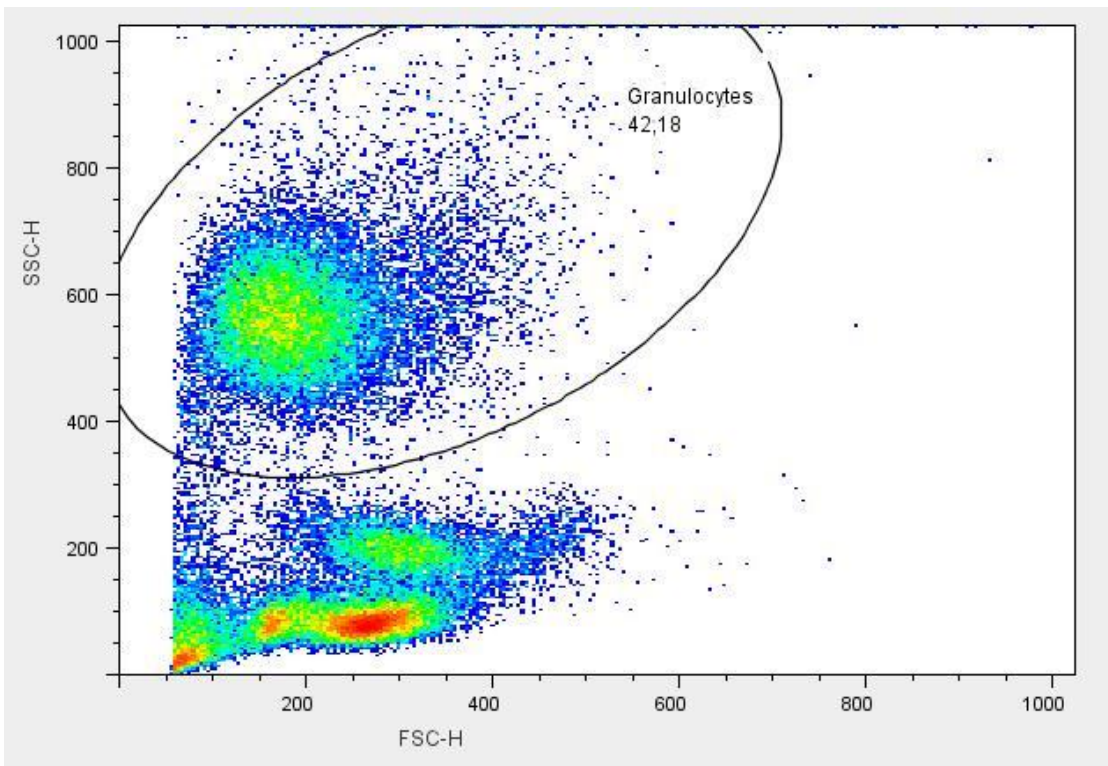

Fonte: Shecaira, 2017.

Figura 2 Histograma demonstrando a porcentagem de células contendo marcador de superfície específico de granulócitos $(\mathrm{CH138+)}$ observadas no gate utilizado para a avaliação dos neutrófilos das amostras de sangue por citometria de fluxo

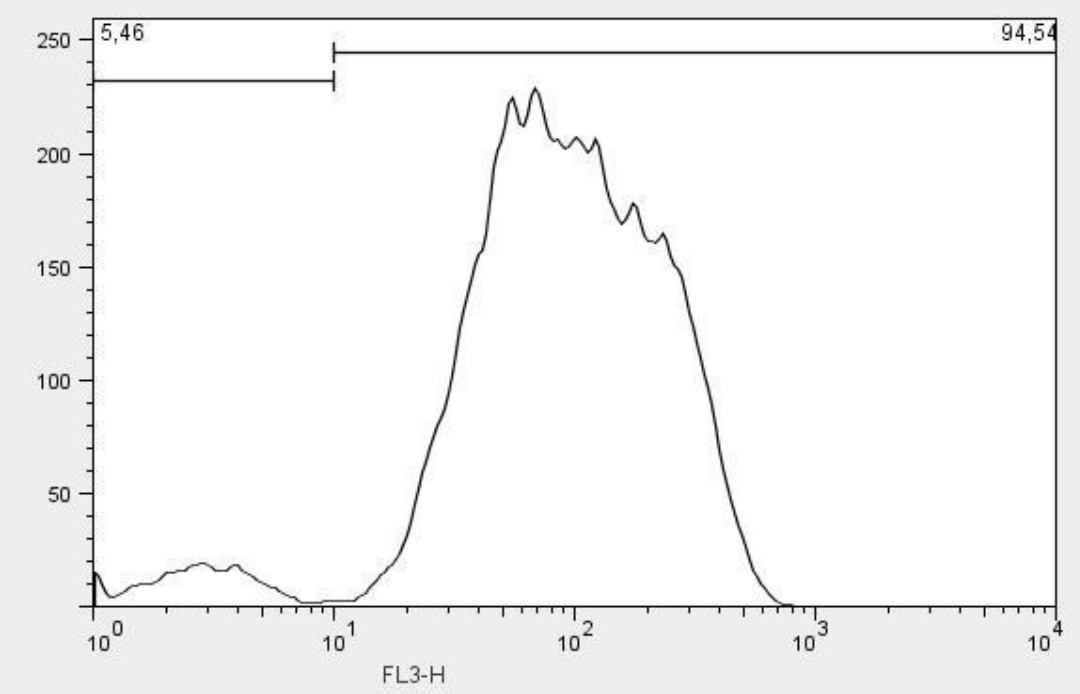

Fonte: Shecaira, 2017. 


\subsection{PCR EM TEMPO REAL COM TRANSCRIÇÃO REVERSA (RT-QPCR)}

Para a avaliação do perfil da resposta imunitária dos neonatos, por meio da expressão do RNAm das citocinas IL-12, IFN- $\gamma$, IL-4 e IL-10 por leucócitos circulantes, utilizou-se da reação em cadeia da polimerase (PCR) em tempo real por transcrição reversa. Os protocolos utilizados são descritos a seguir.

\subsubsection{Conservação das amostras}

Imediatamente após a coleta, os tubos heparinizados contendo as amostras de sangue foram centrifugados a $800 \times \mathrm{g}$, durante 30 minutos, a $4^{\circ} \mathrm{C}$, para a separação da camada leucocitária. Dentro de um fluxo laminar, previamente limpo com álcool 70\% e esterilizado por meio de radiação de luz ultravioleta durante 15 minutos, a camada leucocitária foi aspirada com o auxílio de pipeta Pasteur estéril e despejada, em duplicata, dentro de tubos cônicos estéreis (livres de nucleases, com capacidade para $15 \mathrm{~mL}$ ), contendo $1 \mathrm{~mL}$ de RPMI ${ }^{16}$ estéril.

Em seguida, procedeu-se à lise osmótica de hemácias, utilizando-se $2 \mathrm{~mL}$ de água tratada com $\mathrm{DEPC}^{17}$. Estes tubos cônicos foram, então, centrifugados a $10.000 \mathrm{x} G$, durante oito minutos a $4^{\circ} \mathrm{C}$. Na sequência, o sobrenadante foi desprezado, o botão, ressuspendido em $500 \mu \mathrm{L}$ de Trizol $^{\circledR}{ }^{18}$ e as alíquotas, transferidas para microtubos estéreis (livre de nucleases, com capacidade para 1,5 mL). Os microtubos foram etiquetados com o número do animal e tempo da coleta e, em seguida, foram congelados a $-80^{\circ} \mathrm{C}$ para posterior extração do RNA.

\footnotetext{
${ }^{16}$ Roswell Park Memorial Institute - RPMI-1640 - Sigma ${ }^{\circledR}$, St. Louis, MO; no. cat. R7638.

17 Água Milli-Q tratada com dietilpirocarbonato [DEPC] 1:1000 [v/v], por 12 horas, sob agitação a $37^{\circ} \mathrm{C}$, e autoclavada por $15-20$ minutos, a $121^{\circ} \mathrm{C}$.

${ }^{18}$ Trizol® Reagent - Life Technologies $®$, Carlsbad, CA; no. cat. 15596018.
} 


\subsubsection{Extração do RNA}

Para a realização da extração do RNA total utilizou-se um kit comercial ${ }^{19}$, seguindo o protocolo recomendado pelos fornecedores, perfazendo um volume final de $30 \mu \mathrm{L}$. Para a confirmação da presença de RNA no material extraído, foram colhidos $8 \mu \mathrm{L}$ de cada amostra e, com o auxílio de um fluorômetro ${ }^{20}$, determinou-se a concentração estimada de RNA. As amostras foram, então, novamente congeladas a $-80^{\circ} \mathrm{C}$, para posterior produção de DNA complementar.

\subsubsection{Controle positivo}

Com a finalidade de posterior comparação entre os resultados de CT (Threshold Cycle ou ciclo limite) das amostras, utilizou-se uma mesma amostra em todas as placas de reação de RT-qPCR.

Essa amostra foi denominada controle positivo, obtida de um único animal, um bovino, adulto, macho e hígido. A colheita de tal amostra foi realizada em um único momento, por venopunção jugular, utilizando-se sistema a vácuo, em 10 tubos siliconizados com heparina. Estes tubos também foram identificados e transportados, sob-refrigeração, até o laboratório Departamento de Clínica Médica da FMVZ/USP. Imediatamente após a coleta, os tubos contendo as amostras de sangue foram centrifugados para a obtenção da camada leucocitária. Dentro do fluxo laminar, esta camada foi aspirada e colocada dentro de microtubos estéreis, contendo $1 \mathrm{~mL}$ de RPMI estéril, seguindo-se o protocolo para a obtenção de leucócitos utilizado para os bezerros.

Para a extração do RNA total do controle positivo utilizou-se o protocolo de extração com Trizol@, devido ao grande volume de amostra.

\footnotetext{
${ }^{19}$ Pure Link TM RNA Mini Kit@ - Life Technologies®, Carlsbad, CA; no. cat. $12183018^{\text {a }}$.

${ }^{20}$ QubitTM - Life Technologies®, Carlsbad, CA; no. cat. Q32866.
} 


\subsubsection{Tratamento com enzima DNAse}

Anteriormente à síntese de DNA complementar por transcrição reversa, as amostras passaram por um tratamento com a enzima DNAse, utilizando-se de kit comercial ${ }^{21}$ de acordo com as instruções do fabricante.

\subsubsection{Síntese de DNA complementar (cDNA)}

Imediatamente após o tratamento com DNAse, as amostras foram submetidas a síntese de DNA complementar por transcrição reversa, por meio da adição de $10 \mu \mathrm{L}$ da mistura do kit comercial $^{22}$ (seguindo as proporções dos reagentes recomendadas pelo fabricante) em $10 \mu \mathrm{L}$ da amostra contendo RNA total, sendo incubadas a $37^{\circ} \mathrm{C}$ durante 1 hora. Posteriormente, as amostras foram armazenadas em freezer a $-20^{\circ} \mathrm{C}$ até o momento da realização do PCR em tempo real.

Para a síntese de DNA complementar da amostra controle positivo, utilizou-se um kit comercial para síntese de DNA complementar ${ }^{23}$ com capacidade de converter em DNA complementar até $2 \mathrm{mg}$ de RNA.

Para o procedimento de síntese de DNA complementar da amostra controle positivo adicionou-se $10 \mu \mathrm{L}$ da mistura do kit comercial ${ }^{24}$ (seguindo as proporções de reagentes recomendadas pelo fabricante) em $10 \mu \mathrm{L}$ da amostra contendo RNA total, que foram incubados a $25^{\circ} \mathrm{C}$, durante 10 minutos, a $37^{\circ} \mathrm{C}$, durante 120 minutos, e a $85^{\circ} \mathrm{C}$ durante 5 minutos. Posteriormente, as amostras de controle positivo foram armazenadas em freezer a $20^{\circ} \mathrm{C}$ até o momento da realização da PCR em tempo real.

\footnotetext{
${ }^{21}$ DNAse I grau de amplificação Invitrogen® Corp., Carlsbad, CA; no. cat. 18068-015

${ }^{22}$ Sensiscript RT Kit, Qiagen®, no. cat. 205213.

${ }^{23}$ High capacity cDNA Reverse Transcription TM - Kit, Applied Biosystems ${ }^{\circledR}$, Foster City, CA. No. cat. 4374966.

${ }^{24}$ High-Capacity cDNA Reverse Transcription Kit Applied Biosystems ${ }^{\circledR}$, Foster City No.cat. 4368814.
} 


\subsubsection{PCR em tempo real}

Para a realização da PCR em tempo real, adquiriu-se os ensaios de expressão inventoriados para detecção e quantificação de sequências gênicas que codificam as citocinas de bovinos $^{25}$, com oligonucleotídeos iniciadores (primers) e sondas específicas conforme demonstrado no quadro 3. As amostras foram analisadas em duplicata, e para tal, preparou-se uma mistura contendo $1,0 \mu \mathrm{L}$ do ensaio de expressão gênica, $10 \mu \mathrm{L}$ de mix TaqMan e 7,5 $\mu \mathrm{L}$ de água livre de RNA, que foram adicionados a $2 \mu \mathrm{L}$ de cDNA de cada amostra em cada poço da placa próprias para $\mathrm{qPCR}^{26}$ contendo 96 poços. Em cada placa foram adicionados, em duplicatas, amostras de cDNA do controle positivo para garantir o funcionamento da reação. Também em cada placa foram adicionados em duplicata $2 \mu \mathrm{L}$ de água DEPC como controle negativo. Para a amplificação por PCR, utilizou-se o equipamento 7500 Real Time PCR System ${ }^{27}$ com a programação de 10 minutos de $95^{\circ} \mathrm{C}$, seguidos de 45 ciclos de 15 segundos, a $95^{\circ} \mathrm{C}$, e de 1 minuto, a $60^{\circ} \mathrm{C}$. A normalização foi feita pela diferença com o gene de referência. Para tal, foi adquirida da empresa Applied Biosystems ${ }^{\circledR}$, um ensaio ${ }^{28}$ prédesenhado de Beta-actina de bovinos.

Quadro 3- Descrição dos desenhos dos primers de cada gene alvo e do gene de referência adquiridos da empresa Applied Biosystems ${ }^{\circledR}$, utilizados no presente estudo.

\begin{tabular}{|ll|}
\hline Interleucina-4 & Primer \\
\hline Interleucina-10 & Bt-03211898-m1 \\
\hline Interleucina-12 & Bt-03212727-m1 \\
\hline Interferon-gama & Bt-03213922-m1 \\
\hline Beta-actina & Bt-03212723-m1 \\
\hline
\end{tabular}

Fonte: Shecaira, 2017.

\footnotetext{
${ }^{25}$ TaqMan® MGB probes, FAM ${ }^{\mathrm{TM}}$ dye-labeled, Applied Biosystems ${ }^{\circledR}$, Foster City, CA.

${ }^{26}$ MicroAmp® Optical 96-Well Reaction Plate; $n^{\circ}$. cat. N8010560.

27 Applied, Biosystems $®$.

${ }^{28}$ TaqMan ${ }^{\circledR}$ MGB probes, FAM ${ }^{\mathrm{TM}}$ dye-labeled.
} 


\subsubsection{Eficiência de amplificação}

Buscando-se validar a eficiência de amplificação (E) de cada gene estudado, fez-se uma curva padrão com sete pontos de diluição em duplicata, na concentração de 1:10 de cada gene alvo e do gene de referência, e usando-se a fórmula: $\mathrm{E}=\mathrm{e}(-1 / \mathrm{slope})-1$, obteve-se a eficiência de cada reação, descrita a seguir: Beta-actina- 86,90\%; Interferon-gama-100,69\%; Interleucina-10- 94,61\%; Iterleucina-4- 97,33\% e Interleucina-12-95,53\%.

\subsubsection{Analise da expressão gênica}

Para a análise dos resultados de expressão gênica relativa, utilizou-se o método descrito por Pfaffl (2001). Os valores foram calculados com base na proporção entre os Ciclos Limite (treshold cycle-CT) de cada gene alvo e o do gene de referência (Beta-actina), corrigidos pela eficiência da reação, conforme demonstrado na fórmula abaixo:

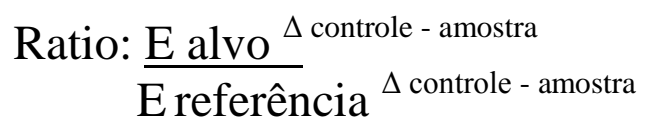

Havendo apenas um grupo experimental, considerou-se como controle, os valores obtidos no tempo 1 (dia 1 pós-nascimento). Os valores encontrados nos demais tempos (dias $3,5,10,15,20,25$ e 30 pós-nascimento) foram considerados amostras.

\subsection{ANÁLISE ESTATÍSTICA}

A distribuição dos resultados do eritrograma, leucograma, atividade fagocítica e metabolismo oxidativo de granulócitos, subpopulações de linfócitos $\mathrm{T} \mathrm{CD}^{+}$e expressão gênica de citocinas foram analisadas por meio de histogramas, gráficos de probabilidade normal e teste de Shapiro-Wilk. A contagem de eritrócitos, hemoglobina, hematócrito e 
CHCM foram normalmente distribuídas. Todas as outras variáveis apresentaram distribuição não-normal.

Estatísticas descritivas foram geradas para avaliar o comportamento de cada variável ao longo dos 30 primeiros dias pós-nascimento (p.n.) de bezerros holandeses com 1, 3, 5, 10, 15, 20, 25 e 30 dias de vida. Para as variáveis normalmente distribuídas, modelos de medidas repetidas (PROC MIXED, SAS Institute, 2011) foram construídos para comparar a média de cada variável ao longo tempo. O pós-teste de Tukey foi utilizado para ajustar os valores $P$ resultantes de comparações múltiplas. O teste de Friedman foi utilizado para comparar as medianas das variáveis com distribuição não-normal ao longo dos 30 dias p.n. De forma semelhante, o pós-teste de Dunn foi utilizado para ajuste do valor $P$. 


\section{RESULTADOS}

Neste tópico serão descritos os resultados dos exames complementares e das análises realizadas por citometria de fluxo e por reação de polimerase em cadeia por transcrição reversa em tempo real, por meio de gráficos e tabelas. Os dados que apresentaram distribuição normal foram analisados por sua média e erro padrão da média, enquanto que aqueles cuja a. distribuição foi não normal por sua mediana e interquartil (Q1 e Q3).

\subsection{TRANSFERÊNCIA DE IMUNIDADE PASSIVA COLOSTRAL}

A fim de garantir que os animais utilizados no presente estudo tivessem adequada transferência de imunidade passiva (TIP) pela ingestão de colostro, realizou-se a avaliação da TIP. Conforme critério originalmente proposto, a transferência de imunidade passiva aos neonatos bovinos, foi considerada adequada quando os animais apresentassem concentrações séricas de proteína total $(\mathrm{PT})$ maiores que $5,0 \mathrm{~g} / \mathrm{dL}$, de globulinas superiores a 2,25 g/dL e de Gama Glutamil Transferase (GGT) superiores a 50 UI/L. Confirmando a adequada transferência de imunidade passiva em análise feita no sangue coletado entre as 24 horas p.n e até 48 horas e a correta inserção dos animais baseada nos critérios de inclusão estabelecidos no delineamento experimental, os 20 neonatos incluídos na pesquisa apresentaram os valores séricos médios relacionados na Tabela 1 .

Tabela 1 Resultados médios ( \pm erro padrão da média) dos valores observados na avaliação bioquímica sérica de 20 bezerros da raça Holandesa, durante o primeiro mês de vida.

\begin{tabular}{ccccccc}
\hline $\begin{array}{c}\text { Variável } \\
\text { Dias pós } \\
\text { nascimento }\end{array}$ & \multicolumn{2}{c}{ Proteínas Totais $(\mathbf{g} / \mathbf{d L})$} & & Albumina \\
\cline { 2 - 5 } & Refratômetro & Randox $^{\mathbf{1}}$ & $\begin{array}{c}\text { Globulinas } \\
(\mathbf{g} / \mathbf{d L})\end{array}$ & $\begin{array}{c}\text { Relaçãa } \\
\text { A:G }\end{array}$ & GGT (UI/L) \\
\hline 1 & $6,34( \pm 0,33)$ & $6,39( \pm 0,31)$ & $2,65( \pm 0,09)$ & $3,74( \pm 0,32)$ & $0,89( \pm 0,13)$ & $100,90( \pm 16,60)$ \\
3 & $6,86( \pm 0,16)$ & $6,93( \pm 0,18)$ & $2,69( \pm 0,11)$ & $4,23( \pm 0,16)$ & $0,65( \pm 0,04)$ & $87,50( \pm 20,00)$ \\
\hline
\end{tabular}

${ }^{\mathrm{I}}$ Randox ${ }^{\circledR}$ RX Daytona, São Paulo, SP.

Fonte: Shecaira, 2017. 
Os resultados expostos na tabela1 demonstram que os valores obtidos para proteínas totais, globulinas e GGT se enquadram nas referências de adequada transferência de imunidade passiva via colostro.

\subsection{HEMOGRAMA}

Para o controle da higidez dos animais estudados foram realizados exames complementares como o hemograma nos dias 1, 3, 5, 10, 15, 20, 25 e 30 pós-nascimento dos 20 bezerros. As contagens totais e diferenciais de leucócitos e de hemácias, assim como as avaliações das taxas de hemoglobina e do volume globular e o cálculo dos índices hematimétricos foram realizadas em contador eletrônico de partículas (Mindray ${ }^{\circledR} \mathrm{BC}$ 2800Vet; Mindray Medical International Limited, São Paulo, SP). Os valores médios ( \pm erro padrão) ou medianos (Q1-Q3) verificados nos 20 bezerros selecionados, a cada dia de avaliação, são apresentados nas Tabelas 2 a 4.

Tabela 2. Valores médios ( \pm erro padrão da média) observados no eritrograma de 20 bezerros da raça Holandesa, durante o primeiro mês de vida.

\begin{tabular}{|c|c|c|c|c|c|c|}
\hline \multirow{2}{*}{ Variável } & \multicolumn{2}{|c|}{ Eritrócitos $\left(\mathrm{x10}^{6} / \mu \mathrm{L}\right)$} & \multicolumn{2}{|c|}{ Hemoglobina (g/dL) } & \multicolumn{2}{|c|}{ Hematócrito (\%) } \\
\hline & Média & EP & Média & EP & Média & EP \\
\hline \multicolumn{7}{|c|}{$\begin{array}{l}\text { Dias após o } \\
\text { nascimento }\end{array}$} \\
\hline 1 & $6,57^{\mathrm{a}}$ & 0,28 & 9,26 & 0,44 & 30,29 & 1,55 \\
\hline 3 & $6,70^{\mathrm{ab}}$ & 0,30 & 9,44 & 0,50 & 29,46 & 1,60 \\
\hline 5 & $6,73^{\mathrm{abc}}$ & 0,29 & 9,49 & 0,49 & 29,74 & 1,45 \\
\hline 10 & $7,34^{\mathrm{bcd}}$ & 0,27 & 9,92 & 0,41 & 31,11 & 1,34 \\
\hline 15 & $7,42^{\mathrm{cd}}$ & 0,25 & 9,64 & 0,38 & 30,43 & 1,23 \\
\hline 20 & $7,57^{\mathrm{d}}$ & 0,28 & 9,87 & 0,41 & 30,90 & 1,41 \\
\hline 25 & $7,53^{\mathrm{d}}$ & 0,29 & 9,51 & 0,41 & 29,96 & 1,36 \\
\hline 30 & $7,76^{\mathrm{d}}$ & 0,30 & 9,70 & 0,44 & 30,11 & 1,39 \\
\hline Geral & 7,2 & 0,10 & 9,60 & 0,15 & 30,25 & 0,49 \\
\hline Valor-P & $<0,001$ & & 0,537 & & 0,785 & \\
\hline
\end{tabular}

Letras minúsculas diferentes representam médias diferentes em função da idade.

Fonte: Shecaira, 2017. 
$\mathrm{Na}$ avaliação das médias do eritrograma dos 20 bezerros acompanhados ao longo dos 30 dias pós-nascimento, pode-se observar que os valores médios do número de hemácias apresentaram diferenças $(\mathrm{P}<0,001)$, demonstrando um aumento numérico com a evolução etária, que alcançou valores máximos aos 30 dias de vida $\left(7,76 \times 10^{6} / \mu \mathrm{L}\right)$.

Os valores médios de hemoglobina $(\mathrm{P}=0,537)$ e hematócrito $(\mathrm{P}=0,785)$ não apresentaram diferenças ao longo do período estudado, comportando-se com certa estabilidade.

Tabela 3 Valores médios ( \pm erro padrão) ou medianos (com intervalo interquartil: Q1Q3) dos índices hematimétricos observados no eritrograma de 20 bezerros da raça Holandesa, durante o primeiro mês de vida.

\begin{tabular}{ccccccccc}
\hline \multirow{2}{*}{ Variável } & \multicolumn{4}{c}{ VCM $^{1}(\mathbf{f L})$} & & $\mathrm{HCM}^{2}(\mathrm{pg})$ & \multicolumn{2}{c}{$\mathrm{CHCM}^{3}(\mathrm{~g} / \mathrm{dL})$} \\
\cline { 2 - 8 } & Q1 & Med & Q3 & Q1 & Med & Q3 & Média & EP \\
\hline
\end{tabular}

Dias após o

nascimento

\begin{tabular}{lcccccccc}
1 & 43,70 & $45,10^{\mathrm{a}}$ & 47,70 & 13,35 & $14,00^{\mathrm{a}}$ & 14,65 & $30,64^{\mathrm{a}}$ & 0,25 \\
3 & 41,55 & $43,25^{\mathrm{abc}}$ & 44,90 & 13,45 & $13,80^{\mathrm{ab}}$ & 14,40 & $32,05^{\mathrm{b}}$ & 0,15 \\
5 & 42,05 & $43,00^{\mathrm{ab}}$ & 44,25 & 13,10 & $13,70^{\mathrm{ab}}$ & 14,25 & $31,81^{\mathrm{b}}$ & 0,23 \\
10 & 40,10 & $42,05^{\mathrm{abc}}$ & 43,55 & 12,90 & $13,30^{\mathrm{abc}}$ & 13,70 & $31,90^{\mathrm{b}}$ & 0,28 \\
15 & 38,85 & $40,95^{\mathrm{bcd}}$ & 42,35 & 12,20 & $12,90^{\mathrm{cd}}$ & 13,55 & $31,67^{\mathrm{b}}$ & 0,27 \\
20 & 38,15 & $40,55^{\mathrm{cde}}$ & 42,20 & 12,20 & $12,65^{\mathrm{bcd}}$ & 13,55 & $31,99^{\mathrm{b}}$ & 0,23 \\
25 & 37,10 & $39,65^{\mathrm{de}}$ & 41,60 & 11,75 & $12,30^{\mathrm{d}}$ & 13,15 & $31,82^{\mathrm{b}}$ & 0,21 \\
30 & 35,95 & $39,10^{\mathrm{e}}$ & 40,55 & 11,95 & $12,40^{\mathrm{d}}$ & 12,75 & $32,24^{\mathrm{b}}$ & 0,19 \\
\hline Geral & 39,30 & 41,60 & 43,80 & 12,40 & 13,20 & 13,90 & 31,8 & 0,09 \\
\hline Valor-P & $<0,001$ & & & $<0,001$ & & $<0,001$ & \\
\hline
\end{tabular}

${ }^{1}$ Volume corpuscular médio. ${ }^{2}$ Hemoglobina corpuscular média. ${ }^{3}$. Concentração de hemoglobina corpuscular média. Letras minúsculas diferentes expressam médias ou medianas diferentes em função da idade.

Fonte: Shecaira, 2017

A partir dos dados dispostos na tabela 3, pode-se observar que todos os índices hematimétricos absolutos apresentaram diferenças ao longo dos tempos analisados $(\mathrm{P}<0,001)$.

O volume corpuscular médio (VCM) apresentou valores máximos no primeiro dia pós-nascimento (p.n.) (45,10 fL). Seguindo com decréscimo gradual, e alcançando valores mínimos aos 30 dias p.n. (39,10 fL). Com comportamento similar, os valores de Hemoglobina Corpuscular Média (HCM) mostraram diferenças entre si, sendo seu valor máximo observado 
no primeiro dia p.n. (14,00 pg), decaindo ao longo do tempo e alcançando valores mínimos aos 25 dias p.n (12,30 pg).

Ao contrário do HCM e VCM, a Concentração de Hemoglobina Corpuscular Média (CHCM) apresentou valor mínimo no primeiro dia p.n. (30,64 g/dL), tendo aumento significativo aos três dias p.n. e estabilização dos valores durante o período estudado. 
Tabela 4 Valores medianos (com intervalo interquartil: Q1-Q3) da contagem total e diferencial de leucócitos observados no leucograma de 20 bezerros da raça Holandesa, durante o primeiro mês de vida.

\begin{tabular}{|c|c|c|c|c|c|c|c|c|c|c|c|c|}
\hline \multirow[t]{2}{*}{ Variável } & \multicolumn{3}{|c|}{ Leucócitos $\left(10^{3} / \mu \mathrm{L}\right)$} & \multicolumn{3}{|c|}{ Linfócitos $\left(10^{3} / \mu \mathrm{L}\right)$} & \multicolumn{3}{|c|}{ Monócitos $\left(10^{3} / \mu \mathrm{L}\right)$} & \multicolumn{3}{|c|}{ Granulócitos $\left(10^{3} / \mu \mathrm{L}\right)$} \\
\hline & Q1 & Med & Q3 & Q1 & Med & Q3 & Q1 & Med & Q3 & Q1 & Med & Q3 \\
\hline \multicolumn{13}{|c|}{ Dias pós nascimento } \\
\hline 1 & 7,55 & $10.95^{\mathrm{b}}$ & 14,65 & 1,05 & $1,45^{\mathrm{a}}$ & 1,90 & 0,60 & $0,80^{\mathrm{abc}}$ & 0,95 & 5,70 & $8,50^{\mathrm{b}}$ & 12,30 \\
\hline 3 & 6,35 & $7,80^{\mathrm{a}}$ & 8,95 & 1,20 & $1,50^{\mathrm{a}}$ & 1,85 & 0,60 & $0,65^{\mathrm{a}}$ & 0,70 & 4,60 & $5,60^{\mathrm{ac}}$ & 6,90 \\
\hline 5 & 6,60 & $7,15^{\mathrm{a}}$ & 8,6 & 1,55 & $2,00^{\mathrm{ab}}$ & 2,45 & 0,60 & $0,80^{\mathrm{abc}}$ & 1,00 & 3,60 & $4,30^{\mathrm{a}}$ & 5,35 \\
\hline 10 & 7,95 & $11,50^{\mathrm{b}}$ & 14,75 & 1,80 & $2,00^{\mathrm{ab}}$ & 2,55 & 0,80 & $1,00^{\mathrm{c}}$ & 1,30 & 5,25 & $8,05^{\mathrm{a}}$ & 11,90 \\
\hline 15 & 5,55 & $6,70^{\mathrm{a}}$ & 11,05 & 1,75 & $2,55^{\mathrm{bc}}$ & 3,20 & 0,60 & $0,80^{\mathrm{abc}}$ & 1,15 & 2,55 & $3,55^{\mathrm{abc}}$ & 6,60 \\
\hline 20 & 7,40 & $9,15^{\mathrm{ab}}$ & 11,15 & 2,00 & $2,45^{\mathrm{bc}}$ & 2,80 & 0,80 & $1,00^{\mathrm{bc}}$ & 1,15 & 3,85 & $5,5^{\mathrm{ac}}$ & 7,20 \\
\hline 25 & 7,25 & $8,45^{\mathrm{ab}}$ & 10,55 & 2,60 & $2,90^{\mathrm{c}}$ & 3,75 & 0,65 & $0,90^{\mathrm{abc}}$ & 1,10 & 3,50 & $4,60^{\mathrm{bc}}$ & 6,10 \\
\hline 30 & 8,70 & $10,75^{\mathrm{b}}$ & 13,2 & 2,75 & $3,00^{\mathrm{c}}$ & 3,25 & 0,80 & $1,10^{\mathrm{c}}$ & 1,60 & 5,00 & $7,05^{\mathrm{c}}$ & 9,60 \\
\hline Geral & 6,95 & 8,70 & 11,6 & 1,60 & 2,30 & 2,90 & 0,70 & 0,85 & 1,10 & 3,90 & 5,55 & 8,30 \\
\hline Valor-P & & $<0,001$ & & & $<0,001$ & & & $<0,001$ & & & 001 & \\
\hline
\end{tabular}

Letras minúsculas diferentes representam medianas diferentes em função da idade

Fonte: Shecaira, 2017 
Os resultados obtidos das contagens de leucócitos totais, granulócitos, linfócitos e monócitos mostraram diferença ao longo dos momentos estudados.

A contagem de leucócitos totais apresentou valores semelhantes nos dias 1, 10 e 30 p.n. $\left(10,95 \times 10^{3} / \mu \mathrm{L} ; 11,50 \times 10^{3} / \mu \mathrm{L} ; 10,75 \times 10^{3} / \mu \mathrm{L}\right.$, respectivamente). Houve uma diminuição abrupta no dia $15\left(6,70 \times 10^{3} / \mu \mathrm{L}\right)$, posterior à maior taxa observada no dia $10\left(11,50 \times 10^{3} / \mu \mathrm{L}\right)$.

Os granulócitos tiveram oscilações em suas taxas durante o período avaliado. Destacase que seus maiores números foram encontrados no primeiro dia p.n $\left(8,50 \times 10^{3} / \mu \mathrm{L}\right)$, e no dia 10 p.n. $\left(8,05 \times 10^{3} / \mu \mathrm{L}\right)$, e sua menor contagem foi verificada no dia 15 p.n. $\left(3,55 \times 10^{3} / \mu \mathrm{L}\right)$.

A contagem de monócitos apresentou diferenças $(\mathrm{P}<0,001)$ com variação irregular sendo encontrado no dia 3 p.n., o menor valor $\left(0,65 \times 10^{3} / \mu \mathrm{L}\right)$, e um valor máximo aos 30 dias p.n $\left(1,10 \times 10^{3} / \mu \mathrm{L}\right)$.

Os linfócitos apresentaram um discreto e significativo aumento, com a evolução da idade com os menores números verificados nos dias $1\left(1,45 \times 10^{3} / \mu \mathrm{L}\right)$ e 3 p.n. $\left(1,50 \times 10^{3} / \mu \mathrm{L}\right)$ e valor máximo aos 30 dias de vida $\left(3,0 \times 10^{3} / \mu \mathrm{L}\right)$.

\subsection{FAGOCITOSE E METABOLISMO OXIDATIVO}

Os resultados obtidos na avaliação de atividade fagocítica e metabolismo oxidativo de granulócitos por citometria de fluxo do sangue de 20 bezerros da raça Holandesa durante o primeiro mês de vida não apresentaram distribuição normal e foram avaliados por testes não paramétricos. Assim sendo, expressos sob a forma de mediana e intervalo interquartil (Q1 e Q3) e estão apresentados nas Tabelas numeradas de 5 a 10 e nos gráficos de 1 a 11. 
Tabela 5 Valores medianos (com intervalo interquartil: Q1-Q3) da porcentagem de células produzindo EROs frente ao estímulo por meio da fagocitose de SaPI, em granulócitos obtidos de 20 bezerros da raça Holandesa, durante o primeiro mês de vida

\begin{tabular}{|c|c|c|c|c|c|c|c|c|c|c|c|c|}
\hline \multirow{2}{*}{$\begin{array}{l}\text { Variável } \\
\text { Dias p.n. }{ }^{1}\end{array}$} & \multicolumn{3}{|c|}{ Granulócitos (\%) } & \multicolumn{3}{|c|}{ EROs sem estímulo (\%) } & \multicolumn{3}{|c|}{ EROs com estímulo (\%) } & \multicolumn{3}{|c|}{ Aumento EROs } \\
\hline & Q1 & Med & Q3 & Q1 & Med & Q3 & Q1 & Med & Q3 & Q1 & Med & Q3 \\
\hline 1 & 91,73 & 97,79 & 98,00 & 86,51 & $92,85^{\text {bd }}$ & 94,87 & 79,29 & $90,85^{\mathrm{abc}}$ & 93,82 & 0,95 & 1,00 & 1,03 \\
\hline 3 & 74,51 & 80,62 & 86,72 & 74,20 & $85,17^{\mathrm{abc}}$ & 89,54 & 85,26 & $89,05^{\mathrm{ab}}$ & 91,10 & 1,00 & 1,01 & 1,09 \\
\hline 5 & 78,85 & 88,56 & 93,84 & 73,86 & $85,88^{\mathrm{abc}}$ & 90,82 & 72,08 & $83,97^{\mathrm{ab}}$ & 90,07 & 0,97 & 0,99 & 1,05 \\
\hline 10 & 86,87 & 95,16 & 96,33 & 75,56 & $89,60^{\text {abcd }}$ & 90,87 & 81,09 & $90,38^{\mathrm{abc}}$ & 92,08 & 1,00 & 1,01 & 1,06 \\
\hline 15 & 78,91 & 87,81 & 95,55 & 61,79 & $80,67^{\mathrm{a}}$ & 89,57 & 68,86 & $83,14^{\mathrm{a}}$ & 90,27 & 0,98 & 1,01 & 1,06 \\
\hline 20 & 82,50 & 83,58 & 90,24 & 75,40 & $82,77^{\mathrm{a}}$ & 87,50 & 72,25 & $77,53^{\mathrm{a}}$ & 90,73 & 0,89 & 1,01 & 1,03 \\
\hline 25 & 85,53 & 91,69 & 93,17 & 90,01 & $91,97^{\mathrm{bcd}}$ & 94,72 & 88,70 & $91,01^{\mathrm{b}}$ & 94,89 & 0,98 & 1,00 & 1,02 \\
\hline 30 & 83,19 & 93,88 & 96,95 & 89,70 & $93,53^{\mathrm{d}}$ & 96,17 & 89,89 & $94,76^{\mathrm{c}}$ & 95,77 & 0,99 & 1,00 & 1,02 \\
\hline Geral & 83,03 & 90,99 & 95,53 & 79,90 & 88,64 & 92,70 & 77,70 & 89,22 & 93,30 & 0,98 & 1,00 & 1,03 \\
\hline Valor P & & & & & 0,001 & & & 0,001 & & & 0,207 & \\
\hline
\end{tabular}

${ }_{1}^{1}$ p.n.: pós-nascimento; ERO: espécies reativas de oxigênio; SaPI: Staphylococcus aureus conjugados com iodeto de propídio. Letras minúsculas diferentes representam medianas diferentes em função da idade, com p indicado na linha inferior.

Fonte: Shecaira, 2017 
A porcentagem de granulócitos (CH138+) observadas ao longo dos tempos estudados obteve uma média geral de 90,99\%, como consta na tabela 5 .

Nos ensaios de produção de espécies reativas de oxigênio, observou-se diferença nas porcentagens de granulócitos produzindo EROs (nos tempos de coleta), tanto sem estímulo ( $p<0,001)$ como com estímulo ( $p<0,001)$. Observou-se também que, apesar dessas diferenças, o aumento de produção de EROs em relação ao estímulo permaneceu constante $(\mathrm{P}=0,207)$.

$\mathrm{Na}$ porcentagem de granulócitos produzindo EROs sem estímulo, observa-se uma diferença do tempo 1 p.n. em relação aos tempos 15 e 20 dias p.n. Havendo uma maior porcentagem de células produzindo espécies reativas de oxigênio no tempo 1p.n. $(92,85 \%)$ em relação aos tempos $15(80,67 \%)$ e $20(82,77 \%)$ p.n.

No que se refere à porcentagem de células granulocíticas produzindo EROs com estímulo, verificou-se que a maior porcentagem obtida nos dias de vida estudados foi aos 30 dias p.n. (94,76\%), enquanto que a menor porcentagem foi encontrada aos 20 dias p.n. (77,53\%). Foram observadas diferenças entre os tempos $15(83,14 \%)$ e $20(77,53 \%)$ e os tempos $25(91,01 \%)$ e 30 p.n. $(94,76 \%)$ e, também houve diferença entre os tempos 3 $(89,05 \%)$ e 30 p.n $(94,76 \%)$, caracterizando-se em linhas gerais uma queda do valor mínimo aos 20 dias p.n., e retorno aos valores iniciais a partir dos 25 dias p.n.

Para melhor compreensão, estão dispostos, em forma de gráfico, os resultados obtidos para porcentagem de granulócitos produzindo EROs sem estímulo por Staphylococcus aureus marcados com iodeto de propídio (gráfico 1) e porcentagem de granulócitos produzindo ERO com estímulo por Staphylococcus aureus (gráfico 2). 
Gráfico 1. Box plot da porcentagem de granulócitos produzindo EROs sem estímulo por SaPI, em 20 bezerros da raça Holandesa durante o primeiro mês de vida.

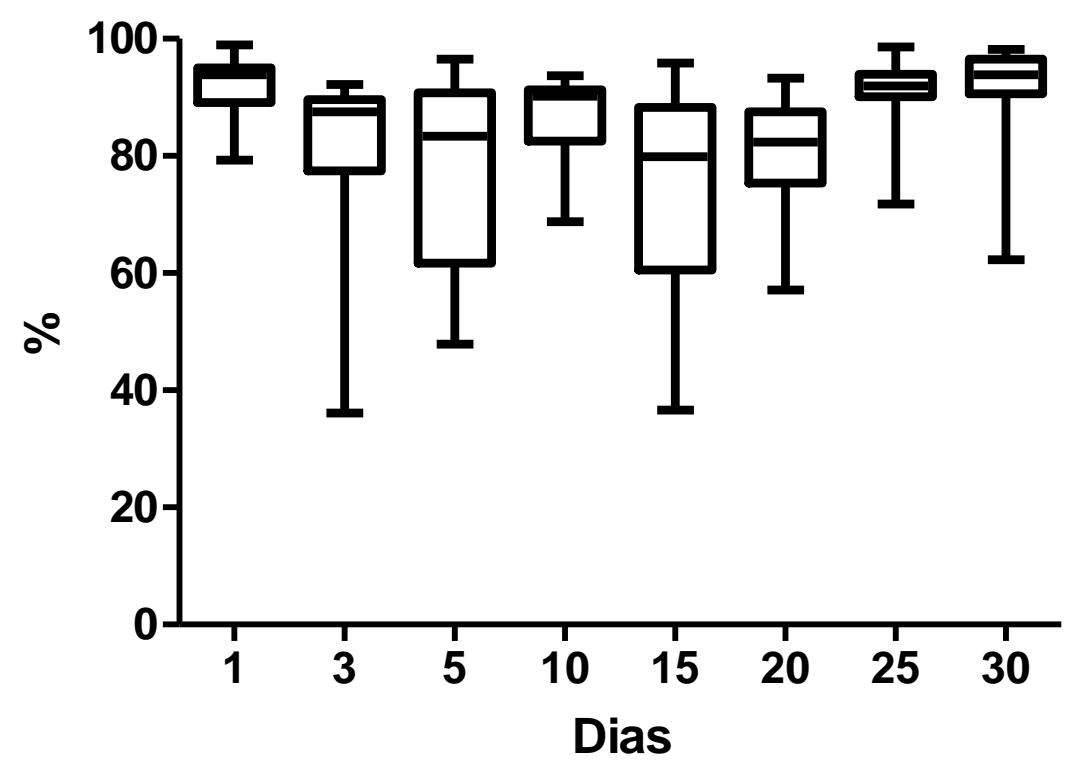

Legenda: EROs.-Espécies reativas de oxigênio; SaPI- Staphylococcus aureus marcados por Iodeto de Propídio. Fonte:Shecaira, 2017.

Gráfico 2. Box plot da porcentagem de granulócitos produzindo EROs com estímulo por SaPI, em 20 bezerros da raça Holandesa durante o primeiro mês de vida.

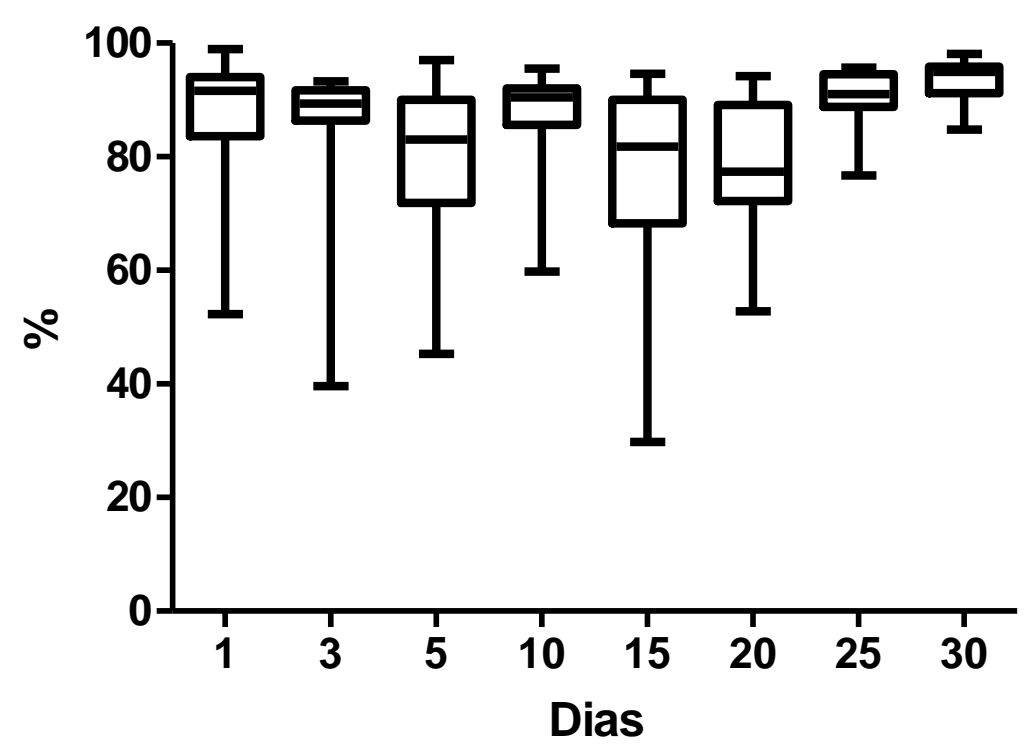

Legenda: EROs-Espécies reativas de oxigênio; SaPI- Staphylococcus aureus marcados por Iodeto de Propídio. Fonte:Shecaira, 2017. 
Tabela 6 Valores medianos (com intervalo interquartil: Q1-Q3) da intensidade de produção de EROs frente ao estímulo por meio da fagocitose de SaPI, por granulócitos obtidos de 20 bezerros da raça Holandesa durante o primeiro mês de vida.

\begin{tabular}{|c|c|c|c|c|c|c|c|c|c|c|c|c|}
\hline \multirow{2}{*}{ Variável } & \multicolumn{3}{|c|}{ Granulócitos (\%) } & \multicolumn{3}{|c|}{ EROs sem estímulo $\left(\right.$ IMF $\left.^{2}\right)$} & \multicolumn{3}{|c|}{ EROs com estímulo $\left(\mathrm{IMF}^{2}\right)$} & \multicolumn{3}{|c|}{ Aumento EROs } \\
\hline & Q1 & Med & Q3 & Q1 & Med & Q3 & Q1 & Med & Q3 & Q1 & Med & Q3 \\
\hline \multicolumn{13}{|l|}{ Dias p.n. ${ }^{1}$} \\
\hline 1 & 91,73 & 97,79 & 98,00 & 216,43 & 820,59 & $3.661,18$ & 227,83 & $953,98^{\mathrm{a}}$ & $3.200,02$ & 0,82 & 0,94 & 2,06 \\
\hline 3 & 74,51 & 80,62 & 86,72 & 110,78 & 486,78 & 999,03 & 85,02 & $318,02^{b}$ & 916,50 & 0,33 & 1,35 & 1,82 \\
\hline 5 & 78,85 & 88,56 & 93,84 & 280,74 & 391,39 & $1.354,58$ & 281,63 & $499,75^{\mathrm{ab}}$ & 898,82 & 0,55 & 1,06 & 1,40 \\
\hline 10 & 86,87 & 95,16 & 96,33 & 126,64 & 420,48 & 987,41 & 185,84 & $416,00^{\mathrm{ab}}$ & 674,91 & 0,60 & 1,09 & 1,35 \\
\hline 15 & 78,91 & 87,81 & 95,55 & 168,87 & 267,17 & 444,86 & 153,49 & $278,43^{\mathrm{ab}}$ & 709,24 & 0,71 & 1,07 & 1,47 \\
\hline 20 & 82,50 & 83,58 & 90,24 & 174,73 & 399,94 & 646,96 & 242,42 & $328,31^{\mathrm{ab}}$ & 718,69 & 0,62 & 0,94 & 1,47 \\
\hline 25 & 85,53 & 91,69 & 93,17 & 164,16 & 450,32 & 986,50 & 123,12 & $458,52^{b}$ & 853,14 & 0,93 & 1,06 & 2,71 \\
\hline 30 & 83,19 & 93,88 & 96,95 & 101,39 & 270,96 & $1.030,92$ & 129,06 & $297,81^{b}$ & $1.030,92$ & 0,59 & 1,02 & 2,06 \\
\hline Geral & 83,03 & 90,99 & 95,53 & 165,16 & 419,07 & 964,52 & 897,3 & 373,48 & 897,3 & 0,66 & 1,06 & 1,75 \\
\hline Valor-P & & & & & 0,059 & & & 0,002 & & & 0,579 & \\
\hline
\end{tabular}

${ }^{1}$ p.n.: pós-nascimento; EROs: espécies reativas de oxigênio; SaPI: Staphylococcus aureus conjugados com iodeto de propídio. ${ }^{2}$ Intensidade de produção de ERO em valores aleatórios da intensidade de fluorescência da diclorofluoresceína. Letras minúsculas diferentes representam medianas diferentes em função da idade, com p indicado na linha inferior. 
A tabela 6 demonstra a intensidade de produção de espécies reativas de oxigênio expressa em valores arbitrários. É possível avaliar que a intensidade de produção de EROs pelos granulócitos sem estimulo pelo Staphylococcus aureus conjugados com iodeto de propídio, não apresentou diferença no decorrer dos momentos analisados $(\mathrm{P}=0,059)$, apresentando uma média geral de 419,7. A intensidade de produção de espécies reativas de oxigênio nas células com estímulo apresentou uma diminuição quando compara-se o tempo 1 $(953,98)$ com valor máximo, com o tempo $3(318,02)$ p.n.. Seguiram as medianas dos tempos 5, 10, 15 e 20 p.n. que não apresentaram diferença entre si, mantendo-se constante.

No tempo 1 observou-se a maior intensidade de produção de espécie reativas de oxigênio $(954,0)$, apresentando diferença em relação aos tempos $3(318,02), 25(458,52)$ e 30 $(297,81)$.

Apesar da diferença observada no ensaio com estímulo, o aumento provocado pelo estimulo não apresentou diferença, permanecendo constante ao longo dos 30 dias com uma média geral de 1,06 .

Os resultados obtidos da intensidade de produção de EROs por granulócitos sem estímulo por Staphylococcus aureus marcados com iodeto de propídio e da intensidade de produção de EROs por granulócitos com estímulo por Staphylococcus aureus marcados com iodeto de propídio estão dispostos, também, sob a forma de gráfico (gráficos 3 e 4 respectivamente) para uma maior compreensão.

\section{Gráfico 3. Box plot da intensidade de produção de EROs por granulócitos sem estímulo por SaPI, em 20 bezerros da raça Holandesa durante o primeiro mês de vida.}

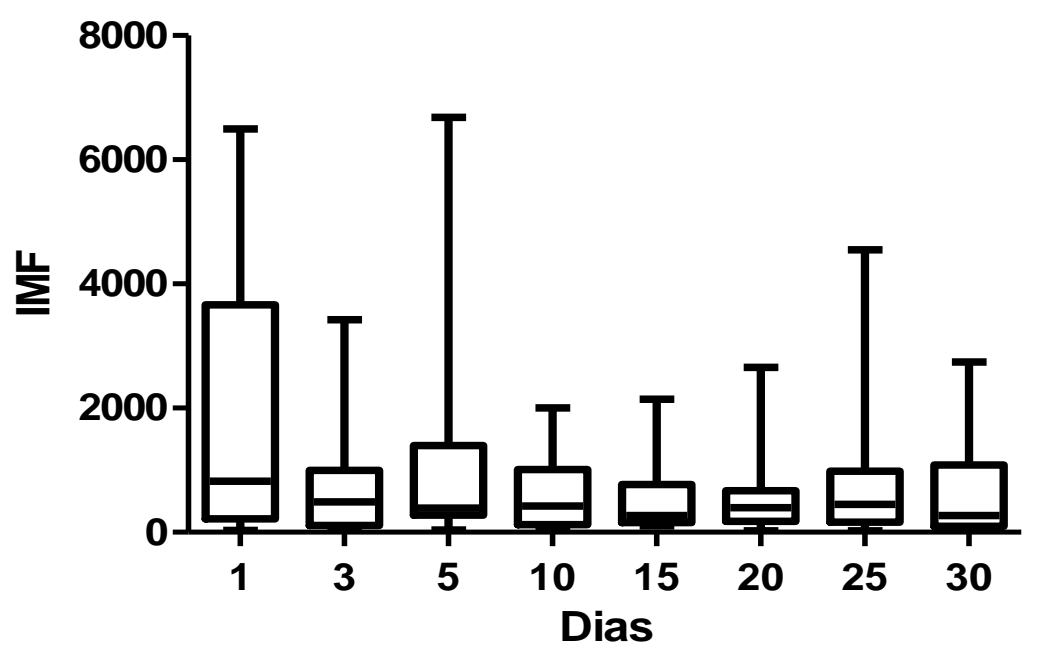

Legenda: EROs- Espécies reativas de oxigênio; SaPI- Staphylococcus aureus marcados por Iodeto de Propídio. Fonte:Shecaira, 2017. 
Gráfico 4. Box plot da intensidade de produção de EROs por granulócitos com estímulo por SaPI, em 20 bezerros da raça Holandesa durante o primeiro mês de vida.

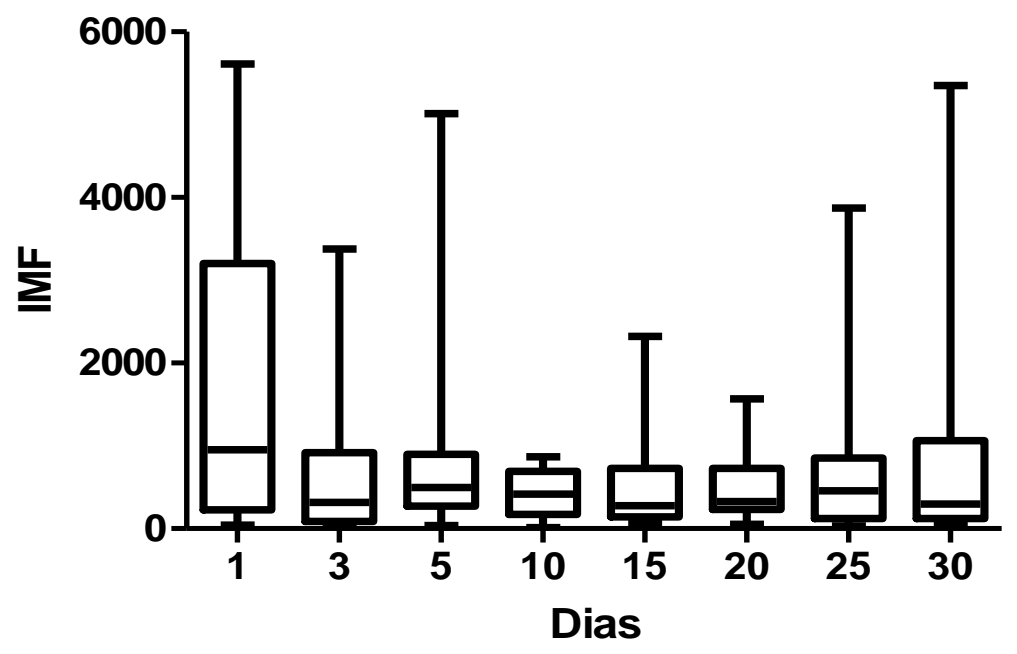

Legenda: EROs- Espécies reativas de oxigênio; SaPI- Staphylococcus aureus marcados por Iodeto de Propídio. Fonte:Shecaira, 2017.

Na tabela 7 encontram-se os resultados das medianas da porcentagem de granulócitos fagocitando Staphylococcus aureus marcados com iodeto de propídio e a intensidade desta fagocitose.

$\mathrm{Na}$ avaliação estatística, não se encontrou diferença para a porcentagem de fagocitose $(\mathrm{P}=0,492)$ e nem para a intensidade desta fagocitose $(\mathrm{P}=0,588)$ no decorrer dos 30 dias avaliados. Obteve-se uma média geral de 20,5 \% de granulócitos que fagocitaram SaPI e uma média geral de 47,6 de intensidade desta fagocitose expressa em valores arbitrários. 
Tabela 7 Valores medianos (com intervalo interquartil:Q1-Q3) da fagocitose de SaPI por granulócitos obtidos de 20 bezerros da raça Holandesa, durante o primeiro mês de vida.

\begin{tabular}{|c|c|c|c|c|c|c|c|c|c|}
\hline \multirow{2}{*}{ Variável } & \multicolumn{3}{|c|}{ Granulócitos (\%) } & \multicolumn{3}{|c|}{ Granulócitos fagocitando SaPI (\%) } & \multicolumn{3}{|c|}{ Intensidade de fagocitose (IMF) } \\
\hline & Q1 & Med & Q3 & Q1 & Med & Q3 & Q1 & Med & Q3 \\
\hline Dias p. $\mathbf{n}^{1}$. & & & & & & & & & \\
\hline 1 & 91,73 & 97,79 & 98,00 & 4,88 & 17,83 & 29,87 & 38,62 & 56,11 & 95,51 \\
\hline 3 & 74,51 & 80,62 & 86,72 & 14,82 & 28,29 & 54,61 & 35,08 & 69,77 & 149,06 \\
\hline 5 & 78,85 & 88,56 & 93,84 & 13,16 & 18,11 & 28,91 & 27,95 & 57,09 & 121,65 \\
\hline 10 & 86,87 & 95,16 & 96,33 & 15,60 & 23,47 & 29,71 & 35,66 & 46,15 & 64,28 \\
\hline 15 & 78,91 & 87,81 & 95,55 & 13,38 & 17,64 & 29,45 & 28,13 & 55,33 & 72,65 \\
\hline 20 & 82,50 & 83,58 & 90,24 & 5,62 & 16,93 & 31,02 & 34,86 & 44,40 & 56,42 \\
\hline 25 & 85,53 & 91,69 & 93,17 & 17,38 & 22,53 & 27,84 & 25,73 & 40,15 & 57,65 \\
\hline 30 & 83,19 & 93,88 & 96,95 & 10,38 & 20,82 & 23,77 & 27,70 & 35,68 & 50,09 \\
\hline Geral & 83,03 & 90,99 & 95,53 & 12,30 & 20,50 & 29,50 & 34,00 & 47,60 & 74,90 \\
\hline
\end{tabular}

${ }^{\top}$ p.n.: pós-nascimento. SaPI: Staphylococcus aureus conjugados com iodeto de propídio. Letras minúsculas diferentes representam medianas diferentes em função da idade, com p indicado na linha inferior.

Fonte: Shecaira, 2017 
A seguir, também são apresentados gráficos da porcentagem de granulócitos realizando fagocitose de Staphylococcus aureus marcados com iodeto de propídio (gráfico 5) e da intensidade desta fagocitose (gráfico 6).

Gráfico 5. Box plot da porcentagem de granulócitos realizando fagocitose de SaPI, em 20 bezerros da raça Holandesa durante o primeiro mês de vida.

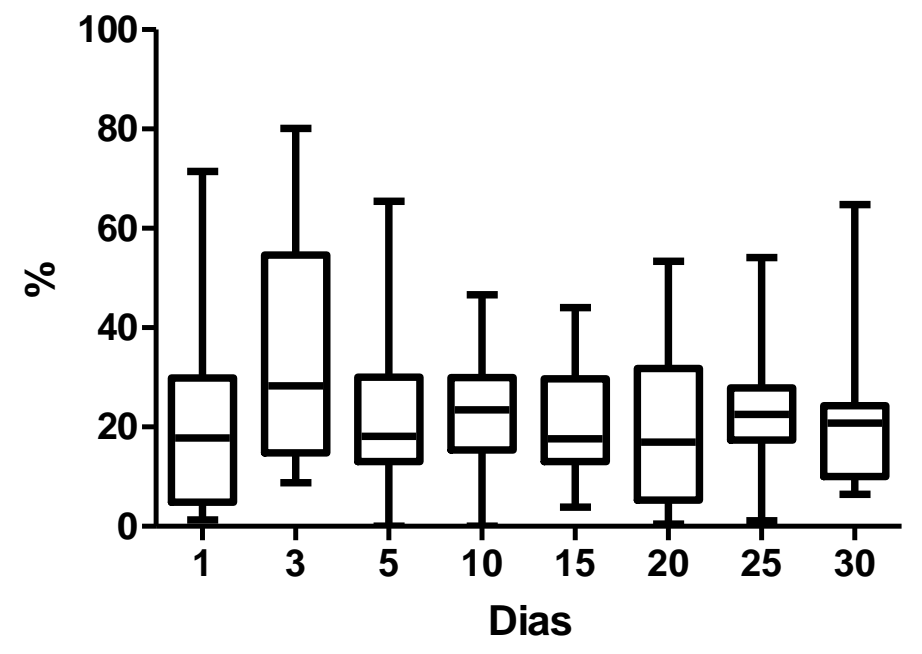

Legenda: SaPI- Staphylococcus aureus marcados por Iodeto de Propídio.

Fonte: Shecaira, 2017

Gráfico 6. Box plot da intensidade de fagocitose de SaPI por granulócitos, em 20 bezerros da raça Holandesa durante o primeiro mês de vida.

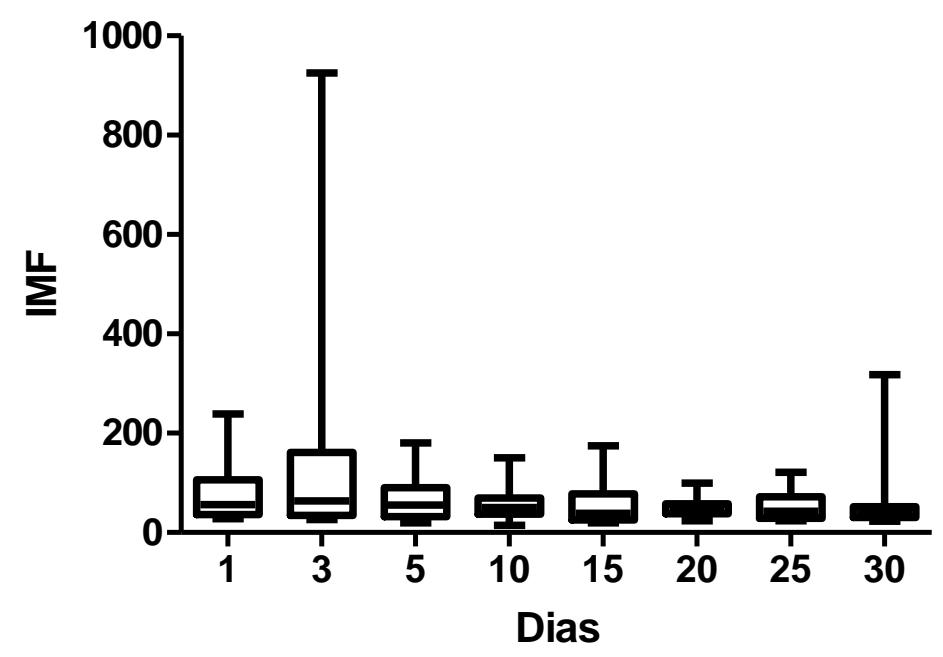

Legenda: SaPI- Staphylococcus aureus marcados por Iodeto de Propídio.

Fonte: Shecaira, 2017 
Os dados de porcentagem de fagocitose, intensidade de fagocitose e intensidade de produção de espécies reativas de oxigênio não apresentaram distribuição normal, portanto foram calculados por teste não paramétrico e seus dados dispostos em valores medianos e intervalo quartil.

Ao se analisar tais dados (contidos na tabela 8), atenta-se que a porcentagem de granulócitos fagocitando SaPI e produzindo EROs, assim como a intensidade desta fagocitose não apresentaram diferença com a evolução etária. $\mathrm{O}$ valor- $\mathrm{P}$ para tais determinações foi de: 0,437 para a porcentagem de granulócitos; 0,799 para a intensidade da fagocitose e de 0,255 para a intensidade de produção de EROs pelos granulócitos que estavam fagocitando SaPI.

Os resultados obtidos para a porcentagem de granulócitos realizando fagocitose de Staphylococcus aureus marcados com iodeto de propídio com produção de EROs, da intensidade desta fagocitose e da intensidade de produção de EROs também estão expostos sob a forma de gráficos para a melhor visualização (gráficos 7 a 9). 
Tabela 8 Valores medianos (com intervalo interquartil: Q1-Q3) da procentagem de células fagocitando SaPI e produzindo EROs, da intensidade da fagocitose e intensidade da produção de EROs, em granulócitos obtidos em 20 bezerros da raça Holandesa, durante o primeiro mês de vida.

\begin{tabular}{|c|c|c|c|c|c|c|c|c|c|c|c|c|}
\hline \multirow[t]{2}{*}{ Variável } & \multicolumn{3}{|c|}{ Granulócitos (\%) } & \multicolumn{3}{|c|}{$\begin{array}{c}\text { Granulócitos fagocitando SaPI e } \\
\text { produzindo EROs }(\%)\end{array}$} & \multicolumn{3}{|c|}{ 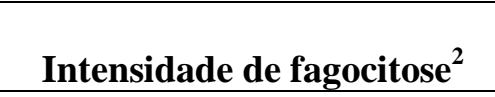 } & \multicolumn{3}{|c|}{$\begin{array}{c}\text { Intensidade de produção de } \\
\text { EROs }^{3}\end{array}$} \\
\hline & Q1 & Med & Q3 & Q1 & Med & Q3 & Q1 & Med & Q3 & Q1 & Med & Q3 \\
\hline \multicolumn{13}{|l|}{ Dias p. ${ }^{1}{ }^{1}$} \\
\hline 1 & 91,73 & 97,79 & 98,00 & 4,04 & 16,44 & 24,94 & 36,39 & 56,46 & 106,41 & 187,79 & 445,81 & $1.636,29$ \\
\hline 3 & 74,51 & 80,62 & 86,72 & 11,89 & 26,60 & 50,89 & 34,40 & 63,41 & 161,23 & 72,32 & 161,88 & 521,07 \\
\hline 5 & 78,85 & 88,56 & 93,84 & 13,42 & 16,13 & 31,08 & 32,31 & 55,20 & 87,22 & 169,19 & 264,64 & 353,52 \\
\hline 10 & 86,87 & 95,16 & 96,33 & 13,83 & 19,55 & 28,80 & 37,13 & 50,69 & 68,90 & 77,80 & 197,24 & 519,34 \\
\hline 15 & 78,91 & 87,81 & 95,55 & 7,58 & 13,92 & 22,70 & 25,51 & 39,15 & 75,11 & 117,36 & 180,01 & 443,64 \\
\hline 20 & 82,50 & 83,58 & 90,24 & 4,48 & 15,35 & 27,82 & 38,32 & 46,51 & 57,57 & 99,25 & 218,70 & 290,13 \\
\hline 25 & 85,53 & 91,69 & 93,17 & 15,69 & 21,77 & 26,03 & 28,53 & 42,96 & 71,98 & 82,86 & 290,63 & 555,51 \\
\hline 30 & 83,19 & 93,88 & 96,95 & 8,69 & 20,09 & 22,86 & 30,37 & 39,06 & 51,40 & 67,49 & 211,95 & 594,72 \\
\hline Geral & 83,03 & 90,99 & 95,53 & 9,39 & 18,56 & 28,43 & 33,79 & 47,70 & 72,00 & 111,80 & 229,40 & 521,10 \\
\hline Valor-P & & & & & 0,437 & & & 0,799 & & & 0,255 & \\
\hline
\end{tabular}

${ }^{1}$ p.n.: pós-nascimento; EROs: espécies reativas de oxigênio; SaPI: Staphylococcus aureus conjugados com iodeto de propídio. Letras minúsculas diferentes representam medianas diferentes em função da idade, com p indicado na linha inferior. ${ }^{2}$ Intensidade de fagocitose em valores aleatórios da intensidade de fluorescência do iodeto de propídio. ${ }^{3}$ Intensidade de produção de EROs em valores aleatórios da intensidade de fluorescência da diclorofluoresceína

Fonte: Shecaira, 2017. 
Gráfico 7. Box plot da porcentagem de granulócitos realizando fagocitose de SaPI com produção de EROs, em 20 bezerros da raça Holandesa durante o primeiro mês de vida.

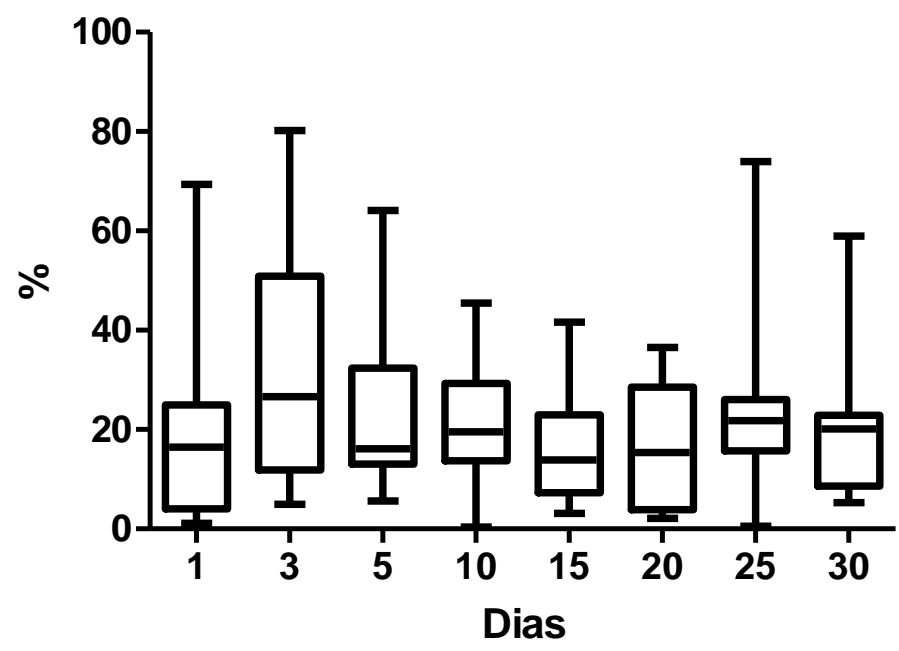

Legenda: SaPI. Staphylococcus aureus marcados por Iodeto de Propídio. EROs: espécies reativas de oxigênio. Fonte:Shecaira, 2017

Gráfico 8. Box plot da intensidade de fagocitose de SaPI com produção de EROs, por granulócitos, em 20 bezerros da raça Holandesa durante o primeiro mês de vida.

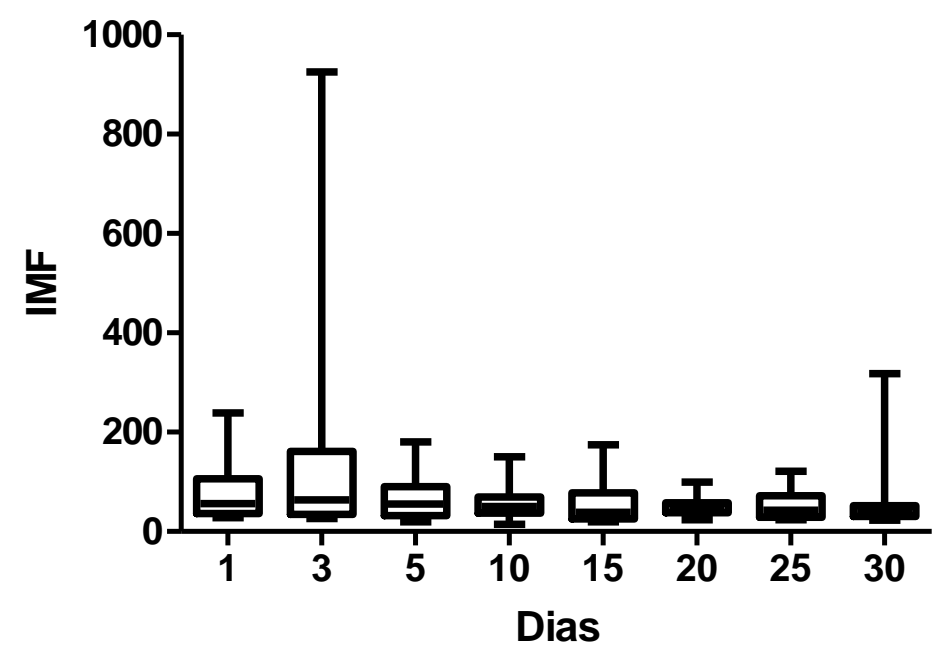

Legenda: SaPI.-Staphylococcus aureus marcados por Iodeto de Propídio; EROs- espécies reativas de oxigênio Fonte:Shecaira, 2017. 
Gráfico 9. Box plot da intensidade de produção de EROs por granulócitos fagocitando SaPI, em 20 bezerros da raça Holandesa durante o primeiro mês de vida.

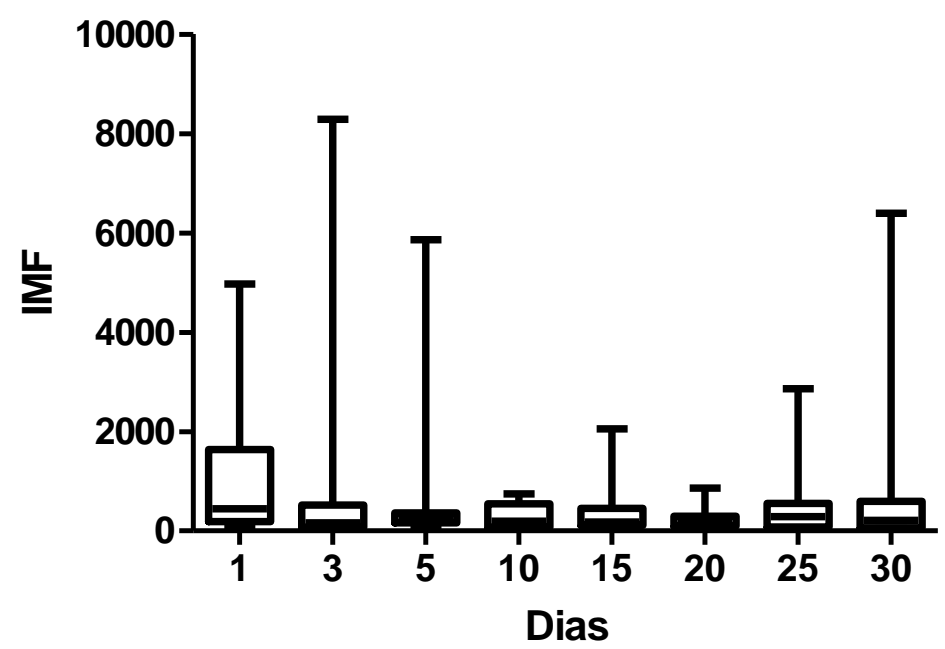

Legenda: SaPI - Staphylococcus aureus marcados por Iodeto de Propídio; EROs- espécies reativas de oxigênio Fonte:Shecaira, 2017.

Como se observa na tabela 8 , uma pequena porcentagem de granulócitos foi encontrada fagocitando as bactérias Staphylococcus aureus marcadas com iodeto de propídio sem produzir espécies reativas de oxigênio. Esta porcentagem de granulócitos não apresentou diferença ao longo dos 30 dias pós-nascimento estudados. Obtendo uma média geral de $0,47 \%$. 
Tabela 9 Valores medianos (com intervalo interquartil:Q1-Q3) da porcentagem e células fagocitando SaPI, sem produção de EROs, e da intensidade de fagocitose ( sem produção de EROs), em granulócitos obtidos em 20 bezerros da raça Holandesa, durante o primeiro mês de vida.

Granulócitos fagocitando SaPI sem produção de EROs

\begin{tabular}{|c|c|c|c|c|c|c|c|c|c|}
\hline \multirow[t]{2}{*}{ Variável } & \multicolumn{3}{|c|}{ Granulócitos (\%) } & \multicolumn{3}{|c|}{$\%$} & \multicolumn{2}{|c|}{ IMF $^{2}$} & \multirow[b]{2}{*}{ Q3 } \\
\hline & Q1 & Med & Q3 & Q1 & Med & Q3 & Q1 & Med & \\
\hline \multicolumn{10}{|c|}{ Dias p.n. ${ }^{1}$} \\
\hline 1 & 91,73 & 97,79 & 98,00 & 0,01 & 0,98 & 1,89 & 21,0 & 31,0 & 245,3 \\
\hline 3 & 74,51 & 80,62 & 86,72 & 0,01 & 1,13 & 1,90 & 26,8 & 109,0 & 271,4 \\
\hline 5 & 78,85 & 88,56 & 93,84 & 0,01 & 0,65 & 4,00 & 21,4 & 32,7 & 518,4 \\
\hline 10 & 86,87 & 95,16 & 96,33 & 0,01 & 0,32 & 0,81 & 24,6 & 30,5 & 159,7 \\
\hline 15 & 78,91 & 87,81 & 95,55 & 0,15 & 0,73 & 2,56 & 41,9 & 87,0 & 255,2 \\
\hline 20 & 82,50 & 83,58 & 90,24 & 0,01 & 0,27 & 1,08 & 22,2 & 30,8 & 100,4 \\
\hline 25 & 85,53 & 91,69 & 93,17 & 0,01 & 0,17 & 1,09 & 24,4 & 37,1 & 109,4 \\
\hline 30 & 83,19 & 93,88 & 96,95 & 0,01 & 0,31 & 1,58 & 23,8 & 48,8 & 112,1 \\
\hline Média & 83,03 & 90,99 & 95,53 & 0,01 & 0,47 & 1,77 & 25,1 & 209,7 & 240,8 \\
\hline Valor P & & & & & 0,131 & & & 0,2 & \\
\hline
\end{tabular}


A intensidade desta fagocitose também não apresentou diferença nos tempos confrontados, sendo sua média geral de 209,7.

$\mathrm{Na}$ tabela 10, observa-se a porcentagem de células produzindo espécies reativas de oxigênio, mas que não estavam fagocitando SaPI, bem como a intensidade desta produção. 
Tabela 10 Valores medianos (com intervalo interquartil: Q1-Q3) da porcentagem de células produzindo EROs e da intensidade desta produção em granulócitos que não estavam fagocitando SaPI, obtidos de 20 bezerros da raça Holandesa, durante o primeiro mês de vida.

\begin{tabular}{|c|c|c|c|c|c|c|c|c|c|}
\hline \multirow{3}{*}{ Variável } & \multicolumn{9}{|c|}{ Granulócitos produzindo EROs sem fagocitose de SaPI } \\
\hline & \multicolumn{3}{|c|}{ Granulócitos (\%) } & \multicolumn{3}{|c|}{$\%$} & \multicolumn{3}{|c|}{ IMF $^{2}$} \\
\hline & Q1 & Med & Q3 & Q1 & Med & Q3 & Q1 & Med & Q3 \\
\hline \multicolumn{10}{|l|}{ Dias p.n ${ }^{1}$. } \\
\hline 1 & 91,73 & 97,79 & 98,00 & 40,56 & $62,64^{\mathrm{ab}}$ & 87,78 & 223,71 & $1082,40 \mathrm{a}$ & $3.288,18$ \\
\hline 3 & 74,51 & 80,62 & 86,72 & 33,92 & $58,62^{\mathrm{a}}$ & 65,56 & 86,73 & $219,64 b$ & $1.035,57$ \\
\hline 5 & 78,85 & 88,56 & 93,84 & 53,52 & $62,66^{\mathrm{ab}}$ & 75,27 & 318,86 & $618,95 \mathrm{ab}$ & $1.051,84$ \\
\hline 10 & 86,87 & 95,16 & 96,33 & 58,05 & $67,31^{\mathrm{ab}}$ & 78,27 & 187,20 & $436,16 a b$ & 792,36 \\
\hline 15 & 78,91 & 87,81 & 95,55 & 46,97 & $66,97^{\mathrm{ab}}$ & 77,48 & 157,55 & $399,30 \mathrm{ab}$ & $1.014,86$ \\
\hline 20 & 82,50 & 83,58 & 90,24 & 49,17 & $62,87^{\mathrm{a}}$ & 69,28 & 252,37 & $391,72 \mathrm{ab}$ & 930,35 \\
\hline 25 & 85,53 & 91,69 & 93,17 & 60,01 & $68,96^{\mathrm{ab}}$ & 73,92 & 128,10 & $605,44 a b$ & 992,50 \\
\hline 30 & 83,19 & 93,88 & 96,95 & 70,56 & $80,57^{\mathrm{b}}$ & 89,87 & 165,83 & $318,28 \mathrm{ab}$ & $1.212,27$ \\
\hline Média & 83,03 & 90,99 & 95,53 & 50,64 & 65,83 & 77,17 & 178,50 & 445,74 & 1035,60 \\
\hline Valor P & & & & & 0,008 & & & 0,009 & \\
\hline
\end{tabular}

${ }^{1}$ p.n.: pós-nascimento; EROs: espécies reativas de oxigênio; SaPI: Staphylococcus aureus conjugados com iodeto de propídio. Letras minúsculas diferentes representam medianas diferentes em função da idade, com p indicado na linha inferior. ${ }^{2}$ Intensidade de produção de EROs em valores aleatórios da intensidade de fluorescência da diclorofluoresceína. 
A porcentagem de granulócitos apresentou diferença entre os tempos de 3 e 20 dias p.n., em relação ao tempo de 30 dias p.n., o qual apresentou a maior porcentagem observada ao longo dos oito tempos estudados.

Quanto à intensidade de produção de EROs, houve diferenças registradas na comparação entre os tempos. Especificamente, entre os tempos 1 e 3 p.n.. Os demais tempos não apresentaram diferença entre si. Destaca-se que no tempo 1 p.n. $(1082,40)$, verificou-se a intensidade máxima desta produção e, no tempo 3 dias p.n. $(219,64)$, a mínima. A seguir os valores medianos se mantiveram estáveis.

Os resultados da porcentagem de granulócitos produzindo EROs sem fagocitose de Staphylococcus aureus marcadas com iodeto de propídio e da intensidade desta produção de EROs também estão dispostos sob a forma de gráficos (gráficos 10 e 11).

Gráfico 10. Box plot da porcentagem de granulócitos produzindo EROs sem fagocitose de SaPI, em 20 bezerros da raça Holandesa durante o primeiro mês de vida.

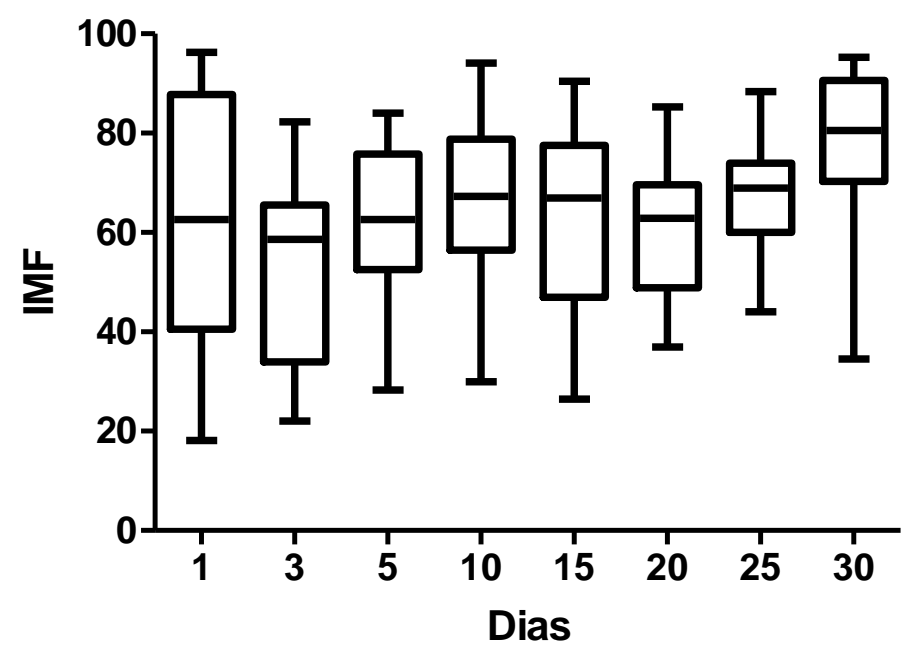

Legenda: SaPI- Staphylococcus aureus marcados por Iodeto de Propídio; EROs- espécies reativas de oxigênio Fonte:Shecaira, 2017. 
Gráfico 11. Box plot da intensidade de produção de EROs por granulócitos que não realizaram fagocitose de SaPI, em 20 bezerros da raça Holandesa durante o primeiro mês de vida.

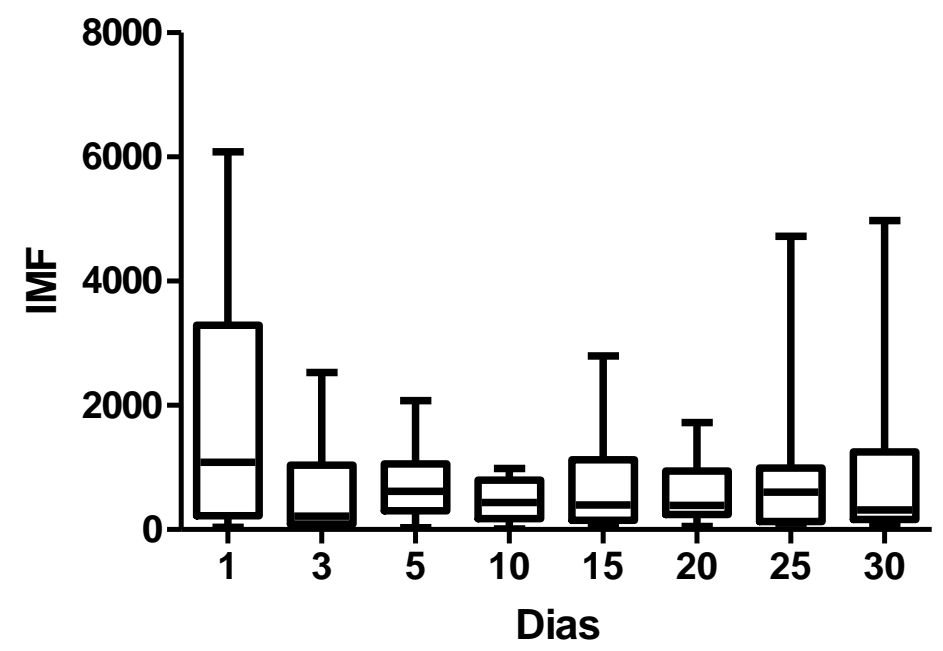

Legenda: SaPI- Staphylococcus aureus marcados por Iodeto de Propídio; EROs- espécies reativas de oxigênio Fonte:Shecaira, 2017.

\subsection{QUANTIFICAÇÃO DAS SUBPOPULAÇÕES DE LINFÓCITOS T CD3+}

Os resultados obtidos das quantidades relativas e a relação entre as quantidades de linfócitos $\mathrm{T} \mathrm{CD}^{+}$e $\mathrm{CD}^{+}$circulantes, utilizando-se de citometria de fluxo, de 20 bezerros selecionados, a cada dia de avaliação não apresentaram distribuição normal e foram analisados por testes não paramétricos, sendo expostos, portanto sob a forma de medianas e intervalos interquartil (Q1 e Q3). Estes resultados estão apresentados na Tabela 11 e nos gráficos 12 a 15 . 
Tabela 11Valores medianos (com intervalo interquartil Q1-Q3) da quantificação das subpopulações de linfócitos T (CD3+) circulantes, obtidos de 20 bezerros da raça Holandesa, durante o primeiro mês de vida.

\begin{tabular}{|c|c|c|c|c|c|c|c|c|c|c|c|c|}
\hline \multirow{2}{*}{ Variável } & \multicolumn{3}{|c|}{$\mathrm{CD3}^{+}(\%)$} & \multicolumn{3}{|c|}{$\mathrm{CD3}^{+} \mathrm{CD4}^{+}(\%)$} & \multicolumn{3}{|c|}{$\mathrm{CD3}^{+} \mathrm{CD8}^{+}(\%)$} & \multicolumn{3}{|c|}{ Relação CD4/CD8 } \\
\hline & Q1 & Med & Q3 & Q1 & Med & Q3 & Q1 & Med & Q3 & Q1 & Med & Q3 \\
\hline \multicolumn{13}{|c|}{$\begin{array}{l}\text { Dias após o } \\
\text { nascimento }\end{array}$} \\
\hline 1 & 39,48 & $48,00^{\mathrm{ab}}$ & 61,41 & 14,68 & $21,28^{\mathrm{ab}}$ & 40,13 & 13,56 & $16,80^{\mathrm{ab}}$ & 19,07 & 0,88 & $1,32^{\mathrm{a}}$ & 1,98 \\
\hline 3 & 39,37 & $45,94^{\mathrm{a}}$ & 57,39 & 4,82 & $12,06^{\mathrm{a}}$ & 20,43 & 10,28 & $13,82^{\mathrm{a}}$ & 18,77 & 0,59 & $0,89^{\mathrm{a}}$ & 1,24 \\
\hline 5 & 49,68 & $54,09^{\mathrm{ab}}$ & 59,95 & 14,35 & $21,19^{\mathrm{abc}}$ & 26,17 & 14,63 & $18,43^{\mathrm{b}}$ & 22,32 & 0,79 & $1,03^{\mathrm{ab}}$ & 1,71 \\
\hline 10 & 32,96 & $55,71^{\mathrm{ab}}$ & 63,41 & 11,72 & $16,02^{\mathrm{ab}}$ & 25,91 & 13,48 & $15,83^{\mathrm{ab}}$ & 19,44 & 0,68 & $1,04^{\mathrm{a}}$ & 2,03 \\
\hline 15 & 43,64 & $50,63^{\mathrm{ab}}$ & 61,60 & 12,04 & $21,17^{\mathrm{bc}}$ & 31,67 & 16,32 & $18,40^{\mathrm{ab}}$ & 20,23 & 0,74 & $1,22^{\mathrm{a}}$ & 1,43 \\
\hline 20 & 52,61 & $66,35^{\mathrm{b}}$ & 72,43 & 16,99 & $22,32^{\mathrm{abc}}$ & 30,70 & 16,14 & $16,79^{\mathrm{b}}$ & 20,50 & 1,01 & $1,38^{\mathrm{ab}}$ & 1,57 \\
\hline 25 & 52,79 & $59,15^{\mathrm{ab}}$ & 65,29 & 16,04 & $25,30^{\mathrm{bc}}$ & 38,12 & 13,59 & $18,46^{\mathrm{ab}}$ & 20,25 & 0,89 & $1,37^{\mathrm{ab}}$ & 1,98 \\
\hline 30 & 51,98 & $52,96^{\mathrm{ab}}$ & 57,35 & 28,63 & $34,53^{\mathrm{c}}$ & 43,03 & 12,92 & $14,79^{\mathrm{ab}}$ & 16,84 & 1,67 & $2,71^{\mathrm{b}}$ & 3,06 \\
\hline Geral & 43,18 & 53,90 & 62,73 & 12,56 & 21,28 & 30,66 & 13,81 & 16,73 & 19,57 & 0,84 & 1,23 & 1,85 \\
\hline Valor $\mathrm{P}$ & \multicolumn{3}{|c|}{0,014} & \multicolumn{3}{|c|}{$<0,001$} & \multicolumn{3}{|c|}{$<0,005$} & \multicolumn{3}{|c|}{$<0,001$} \\
\hline
\end{tabular}

${ }^{1}$ p.n.: pós-nascimento. Letras minúsculas diferentes representam medianas diferentes em função da idade, com p indicado na linha inferior.

Fonte: Shecaira, 2017 
As porcentagens de linfócitos $\mathrm{T}\left(\mathrm{CD}^{+}\right)$apresentaram diferença nos tempos estudados $(\mathrm{P}=0,014)$. Tiveram entre 1 e 15 dias p.n. valores relativamente constantes e a maior porcentagem foi encontrada no tempo $20(66,35 \%)$ enquanto que o dia 3 p.n. apresentou a menor porcentagem $(45,94 \%)$. Os demais momentos $(1,5,10,15,25$ e 30 p.n). apresentaram valores similares.

Os linfócitos $\mathrm{CD}^{+} \mathrm{CD}^{+}$apresentaram diferença ao longo dos tempos observados $(\mathrm{P}<0,001)$. Sua menor porcentagem foi observada no dia 3 p.n. $(12,06 \%)$ e a maior porcentagem encontrada no dia $30(34,53 \%)$.

Para os linfócitos $\mathrm{CD}^{+} \mathrm{CD}^{+}$também houve diferença $(\mathrm{P}<0,005)$, entre os tempos $3(13,82 \%) 5(18,43 \%)$ e $20(16,79 \%)$ p.n..

A relação entre linfócitos $\mathrm{CD}^{+} / \mathrm{CD}^{+}$apresentaram diferença $(\mathrm{P}<0,001)$ na comparação dos tempos $1(1,32), 3(0,89), 10(1,04)$ e $15(1,22)$ em relação ao tempo $30(2,71)$ com valor máximo.

Para melhor visualização dos resultados, estão dispostos também em forma de gráfico as porcentagens de células $\mathrm{CD}^{+}, \mathrm{CD}^{+}$e $\mathrm{CD}^{+}$e a relação entre as porcentagens de células $\mathrm{CD}^{+}$e $^{-} 8^{+}$(gráficos 12 a 15).

Gráfico 12. Box plot dos valores medianos da porcentagem de linfócitos $\mathbf{T}\left(\mathrm{CDB}^{+}\right)$ circulantes em 20 bezerros da raça Holandesa durante o primeiro mês de vida.

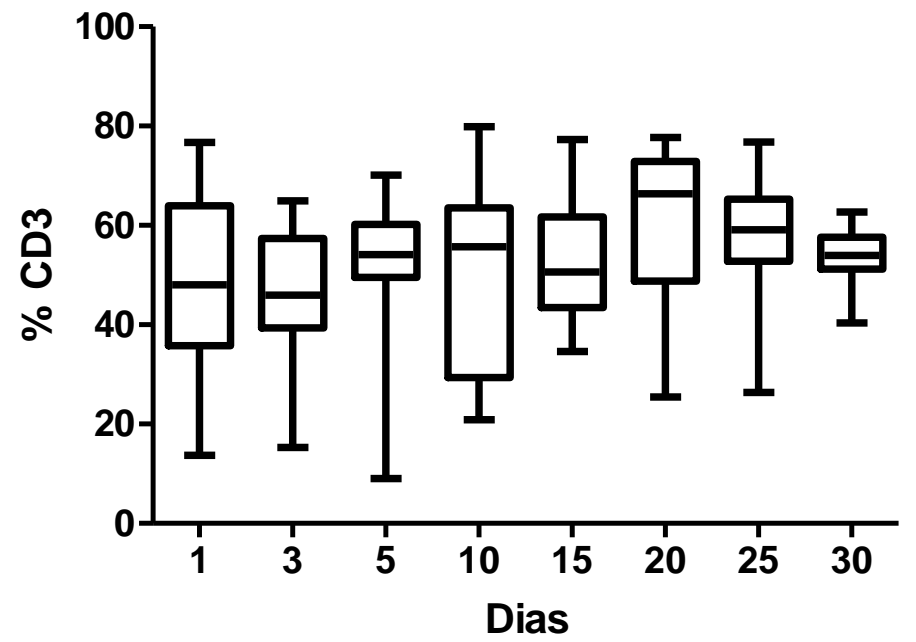

Fonte: Shecaira, 2017. 
Gráfico 13. Box plot dos valores medianos da porcentagem de linfócitos $\mathbf{T}$ auxiliares $\left(\mathrm{CD3}^{+} \mathrm{CD4}^{+}\right)$circulantes em 20 bezerros da raça Holandesa durante o primeiro mês de vida.

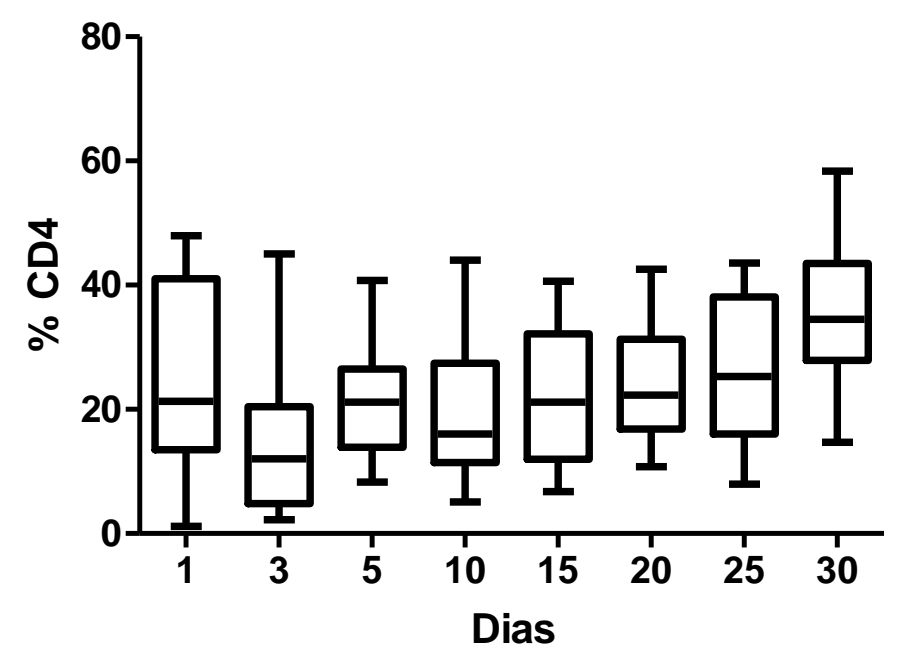

Fonte: Shecaira,2017.

Gráfico 14. Box plot dos valores medianos da porcentagem de linfócitos $\mathbf{T}$ citotóxicos $\left(\mathrm{CD3}^{+} \mathrm{CD8}^{+}\right)$circulantes em 20 bezerros da raça Holandesa durante o primeiro mês de vida.

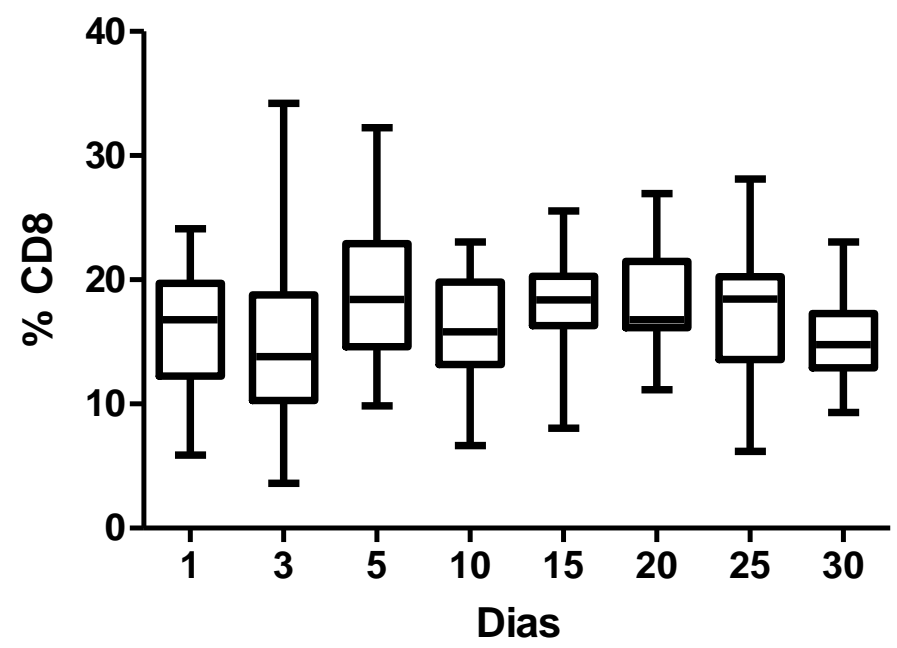

Fonte: Shecaira, 2017. 
Gráfico 15. Box plot dos valores medianos da relação entre linfócitos $\mathbf{T}$ auxiliares $\mathrm{e}$ linfócitos citotóxicos $\left(\mathrm{CD3}^{+} \mathrm{CD4}^{+} / \mathrm{CD3}^{+} \mathrm{CD8}^{+}\right)$circulantes em 20 bezerros da raça Holandesa durante o primeiro mês de vida.

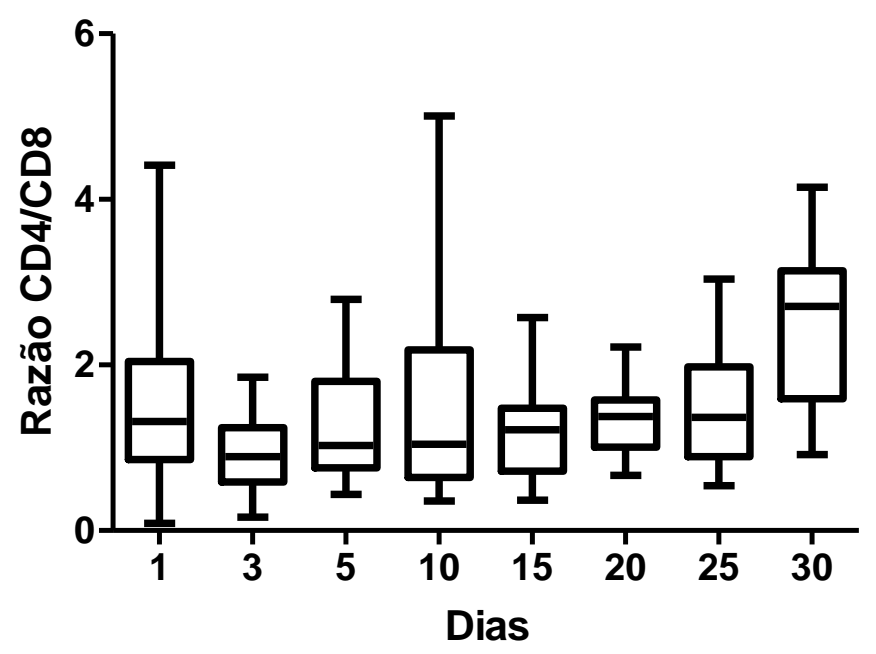

Fonte: Shecaira, 2017

\subsection{EXPRESSÃO GÊNICA DE CITOCINAS}

Para a análise dos resultados de expressão gênica relativa das citocinas IL-4, IL-10, IL-12 e IFN-gama, nos leucócitos dos bezerros, utilizou-se o método descrito por Pfaffl (2001). Seguindo-se esse autor, os valores foram calculados com base entre a proporção entre os Ciclos Limite (Treshold Cycle - CT) de cada gene alvo e o gene de referência (betaactina), corrigidos pela eficiência da reação. Havendo apenas um grupo experimental, considerou-se como controle, os valores obtidos no tempo 1 (dia 1 pós nascimento). Os valores encontrados nos demais tempos (tempos 3, 5, 10, 15, 20, 25 e 30 dias p.n.) foram considerados amostras. Os resultados obtidos são expressos em fold (vezes).

Ao se analisar a interleucina-4, verificou-se que apenas em uma pequena porcentagem de animais foi possível detectar sua expressão gênica ao longo dos tempos estudados, não sendo possível realizar uma análise estatística. O mesmo ocorreu para a citocina Interferon-gama: a pequena quantidade de animais onde se detectou a expressão gênica desta citocina inviabilizou a possibilidade de gerar uma análise estatística. 
Os resultados da análise estatística da expressão gênica da interleucina-10 (tabela 12) não apresentaram diferença nos tempos observados $(\mathrm{P}=0,098)$. Ao longo dos oito tempos analisados, em somente três tempos, além do tempo controle, a expressão gênica desta citocina foi detectada pela técnica utilizada. Sendo eles: dia 1 p.n. (controle); dia 3 p.n. $(1,673)$; dia 10 p.n. $(1,706)$ e dia 25 p.n. $(3,597)$.

A expressão gênica da interleucina-12 também não apresentou diferença ao longo dos tempos observados $(\mathrm{P}=0,833)$. Foi detectada esta expressão gênica apenas nos dias 1 p.n. (controle); 3 p.n. $(1,221)$ e 30 p.n. $(1,939)$ (tabela 12).

Tabela 12 Medianas (com intervalo interquartil:Q1-Q3) da expressão gênica de citocinas IL-10 e IL-12, em função da expressão observada no primeiro mês de vida, por leucócitos obtidos de 20 bezerros da raça Holandesa, durante o primeiro mês de vida

\begin{tabular}{cccc|ccc}
\hline \multirow{2}{*}{ Variável } & \multicolumn{3}{c}{ IL-10 } & \multicolumn{3}{c}{ IL-12 } \\
\cline { 2 - 7 } & $\mathbf{Q 1}$ & Med & $\mathbf{Q 3}$ & $\mathbf{Q 1}$ & Med & Q3 \\
\hline Dias p.n. & & & & Controle & \\
1 & & Controle & & & 1,221 & 1,631 \\
3 & 0,726 & 1,673 & 3,955 & 0,776 & - & \\
5 & & - & & & - & \\
10 & 0,574 & 1,706 & 2,494 & & - & \\
15 & & - & & & - & \\
20 & & & & & 1,939 & 1,947 \\
25 & 1,839 & 3,597 & 3,927 & & 0,833 & \\
30 & & - & & & &
\end{tabular}

Fonte: Shecaira, 2017. 


\subsection{AVALIAÇÃO GERAL DAS VARIÁVEIS ESTUDADAS}

No intuito de estabelecer uma visão mais acurada dos resultados obtidos neste estudo, os resultados de leucograma, fagocitose e metabolismo oxidativo, quantificação de subpopulações linfocitárias e expressão gênica de citocinas dos 20 bezerros holandeses, ao longo dos 30 dias avaliados, são apresentados sob a forma de gráficos, em que é possível observar as variações simultâneas ao longo do tempo (Figuras 3 a 16).

Figura 3 Dinâmica da contagem absoluta de leucócitos: linfócitos, monócitos e granulócitos, de 20 bezerros da raça Holandesa durante o primeiro mês de vida
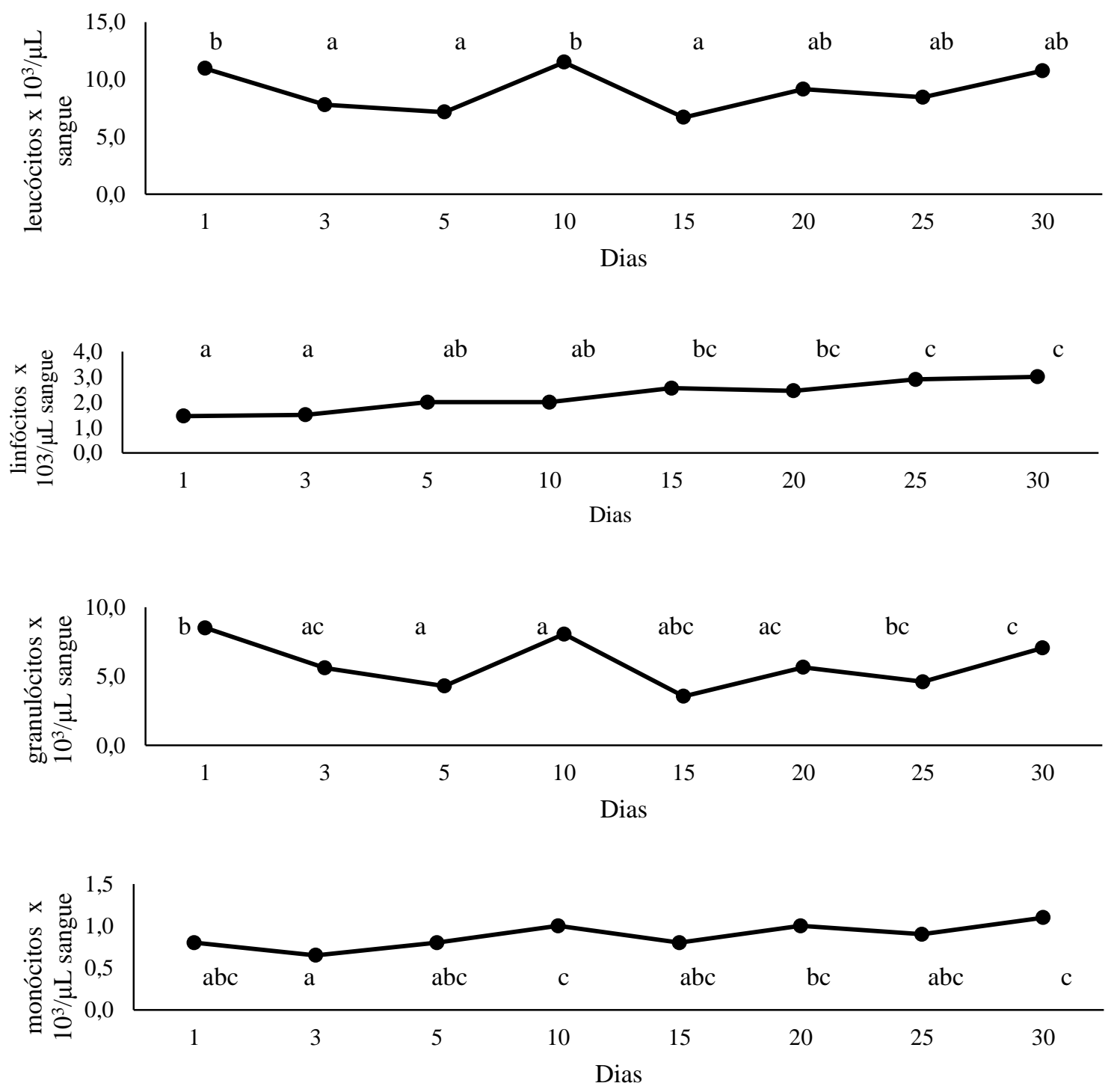

Letras minúsculas diferentes representam diferença entre os tempos.

Fonte: Shecaira,2017. 
Na figura 3 estão dispostos os gráficos das contagens absolutas de leucócitos, linfócitos, monócitos e granulócitos. Ao longo dos tempos estudados, tais contagens apresentaram diferença $(\mathrm{p}<0,001)$.

A contagem total de leucócitos apresentou seus maiores valores nos tempos 1 e 10 p.n. e menores valores nos dias 3, 5 e 15 p.n.. Os linfócitos apresentaram um aumento gradual de suas contagens absolutas ao longo do primeiro mês de vida dos bezerros, seus menores valores foram aos 1 e 3 dias p.n. e seus maiores valores, aos 25 e 30 dias p.n..

Em relação à contagem de monócitos, os maiores valores foram observados nos dias 10 e 30 p.n. enquanto que no dia 3 p.n. foi observada sua menor contagem. Quanto aos granulócitos, foram observadas oscilações em suas contagens ao longo dos 30 dias estudados, o dia 1 p.n. apresentou menores contagens que os dias 5 e 10 p.n. e sua maior contagem foi observada no último dia de coleta (30 p.n.).

As variações dos leucócitos totais refletiram aquelas dos granulócitos seja quando se observou valores maiores, seja quando se registrou os valores menores. Pode-se verificar que aos 30 dias p.n. além do valore relativamente alto dos granulócitos também influenciaram o valor mais alto dos leucócitos totais, os valores máximos dos linfócitos e monócitos. 
Figura 4 Produção de espécies reativas de oxigênio em granulócitos sem estimulo pela fagocitose de Staphylococcus aureus marcados com iodeto de propídio, de 20 bezerros da raça Holandesa durante o primeiro mês de vida: porcentagem e intensidade média de fluorescência (IMF).

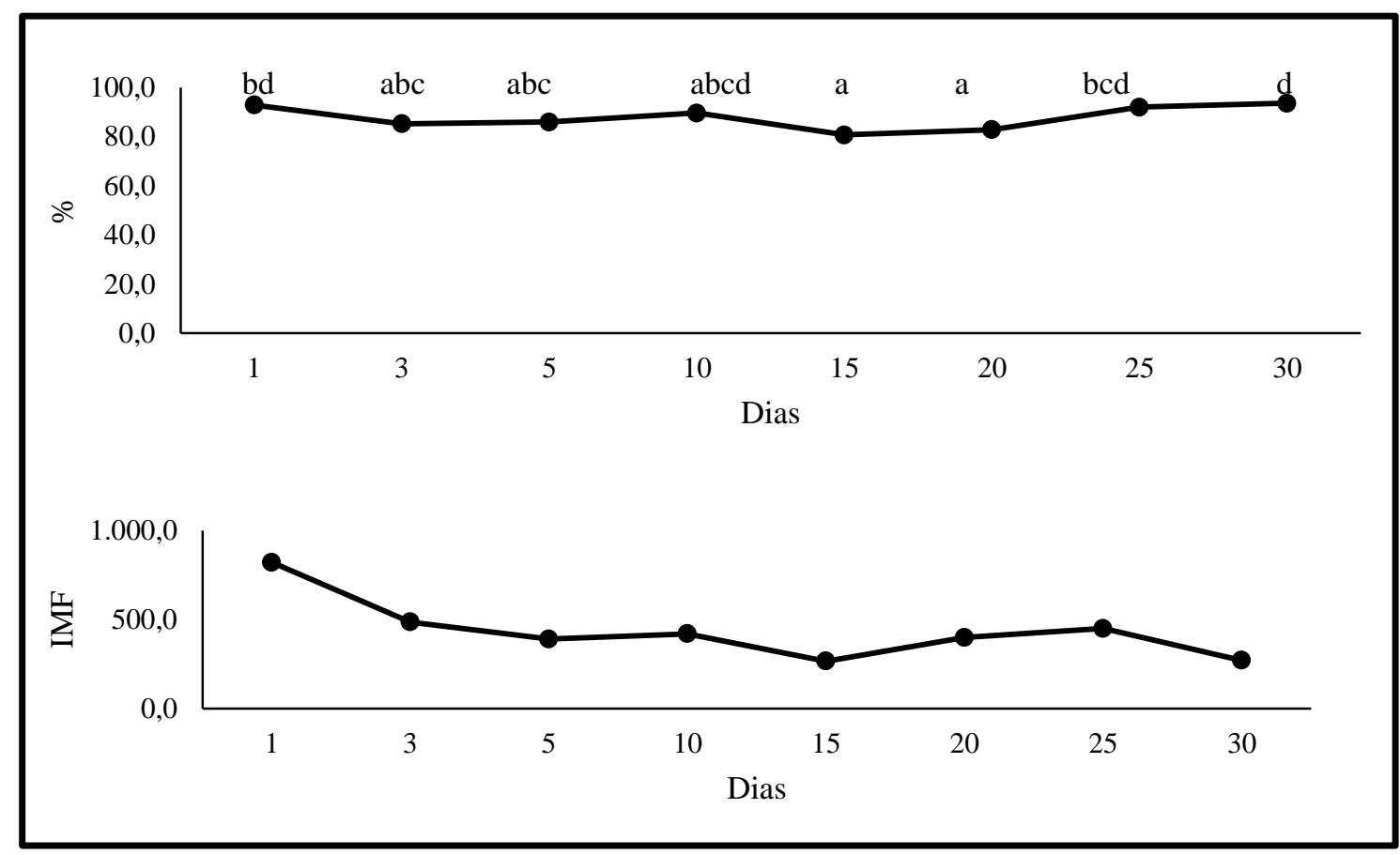

Letras minúsculas diferentes representam diferença entre os tempos.

Fonte: Shecaira,2017.

Figura 5 Produção de espécies reativas de oxigênio em granulócitos com estimulo pela fagocitose de Staphylococcus aureus marcados com iodeto de propídio, de 20 bezerros da raça Holandesa durante o primeiro mês de vida: porcentagem e intensidade média de fluorescência (IMF).

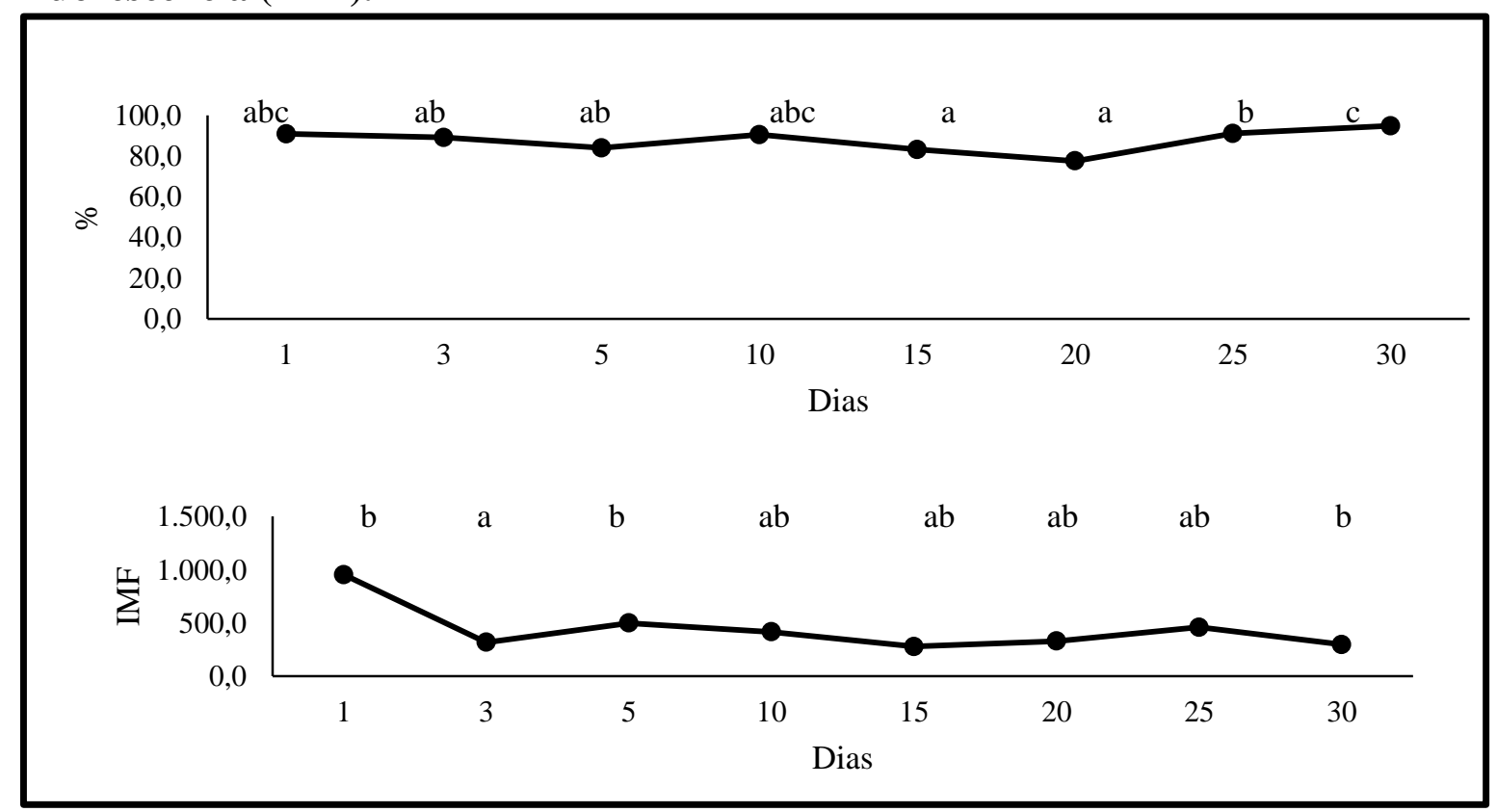

Letras minúsculas diferentes representam diferença estatística entre os tempos. Fonte: Shecaira,2017. 
Figura 6 Aumento de produção de espécies reativas de oxigênio por granulócitos frente ao estimulo pela fagocitose de Staphylococcus aureus marcados com iodeto de propídio, de 20 bezerros da raça Holandesa durante o primeiro mês de vida: porcentagem e intensidade média de fluorescência (IMF).

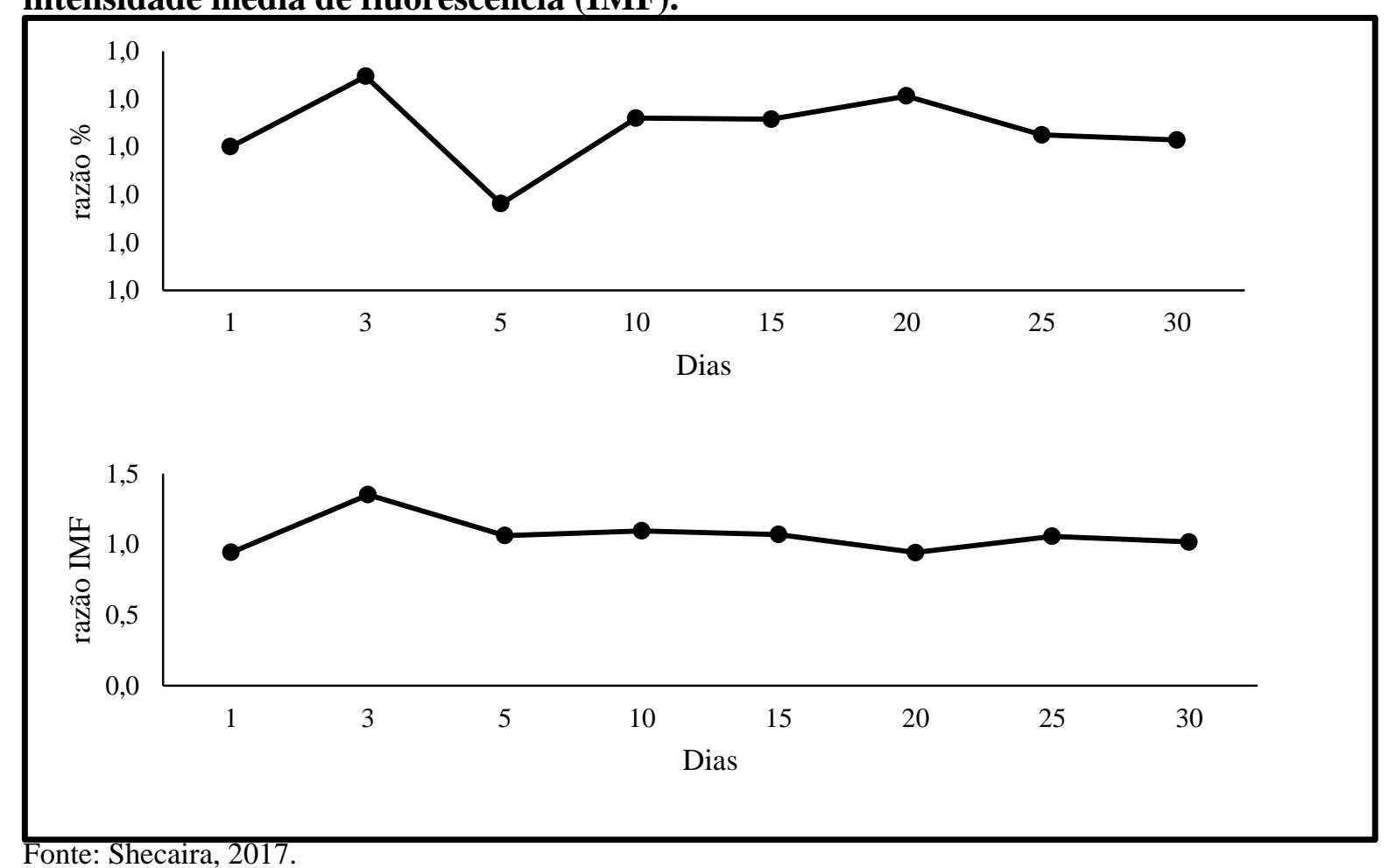

A avaliação dos ensaios de fagocitose e metabolismo oxidativo permitiu a avaliação da influência da fagocitose de SaPI na produção de EROs. Nas figuras 4 e 5, estão dispostos os gráficos de porcentagem e intensidade de fluorescência da produção de espécies reativas de oxigênio por granulócitos sem estimulo e com estímulo pela fagocitose de Staphylococcus aureus marcados com iodeto de propídio, respectivamente. Na figura 6, observa-se o aumento desta porcentagem e da intensidade da fluorescência, em função do estimulo pela fagocitose.

Em relação à porcentagem de granulócitos produzindo espécies reativas de oxigênio, tanto sem estímulo pela fagocitose de SaPI, como com tal estímulo, observou-se uma menor porcentagem de células aos 15 e 20 dias p.n. Nos dias 25 e 30 p.n., observou-se um aumento destas porcentagens para os dois ensaios (sem estímulo e com estímulo).

Quanto à intensidade de fluorescência, o ensaio sem estímulo pela fagocitose não apresentou diferença nos tempos estudados. Contudo, o ensaio com estímulo pela fagocitose de SaPI apresentou diferença para tal intensidade, demonstrando maiores valores nos dias 1, 25 e 30 p.n.. 
Quando são comparadas tais variações de porcentagens de granulócitos produzindo EROs com a variação numérica dos granulócitos (figura 3), nota-se que a contagem absoluta de granulócitos também apresentou maior taxa no dia 30 p.n..

Apesar da diferença encontrada nas porcentagens de granulócitos produzindo EROs sem estímulo e com estímulo, não foi observado diferença no gráfico que descreve o aumento de porcentagem pelo estímulo. O mesmo ocorreu para a intensidade de fluorescência e, por conseguinte, da produção de EROs.

Figura 7 Variação da porcentagem de granulócitos (CH138+) observados no gate utilizado para os ensaios de fagocitose e metabolismo oxidativo, em 20 bezerros da raça Holandesa durante o primeiro mês de vida

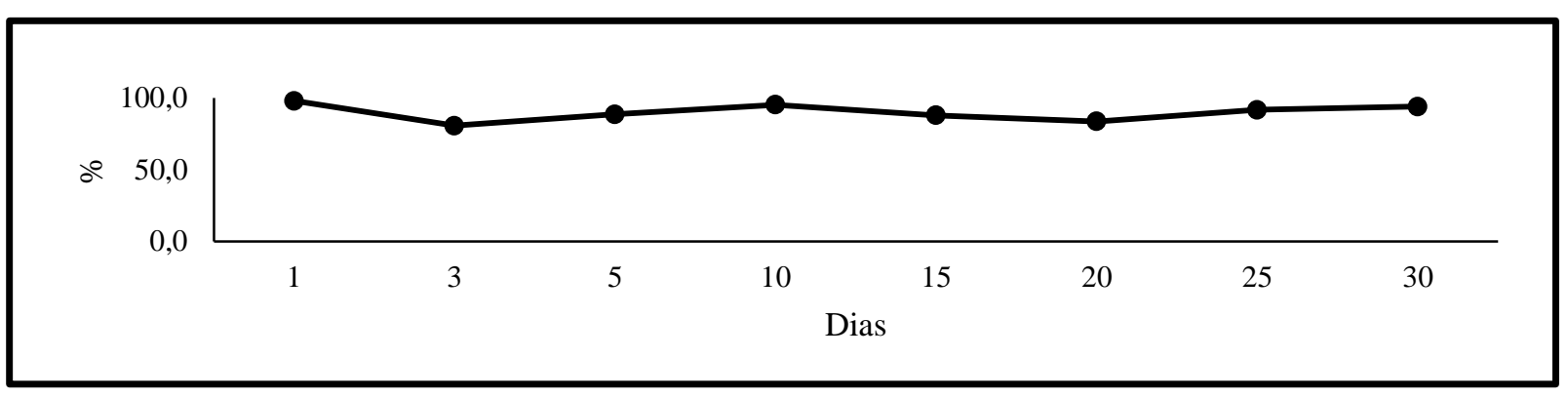

Fonte: Shecaira, 2017

A figura 7 mostra o gráfico da porcentagem de granulócitos (células $\mathrm{CH} 138^{+}$) observadas no gate que foi utilizado para o ensaio de fagocitose e de metabolismo oxidativo. A porcentagem de granulócitos no gate utilizado obteve uma média geral de 90,99\%. 
Figura 8 Dinâmica da porcentagem de granulócitos fagocitando Staphylococcus aureus marcados com iodeto de propídio e da intensidade desta fagocitose (IMF) em 20 bezerros da raça Holandesa durante o primeiro mês de vida

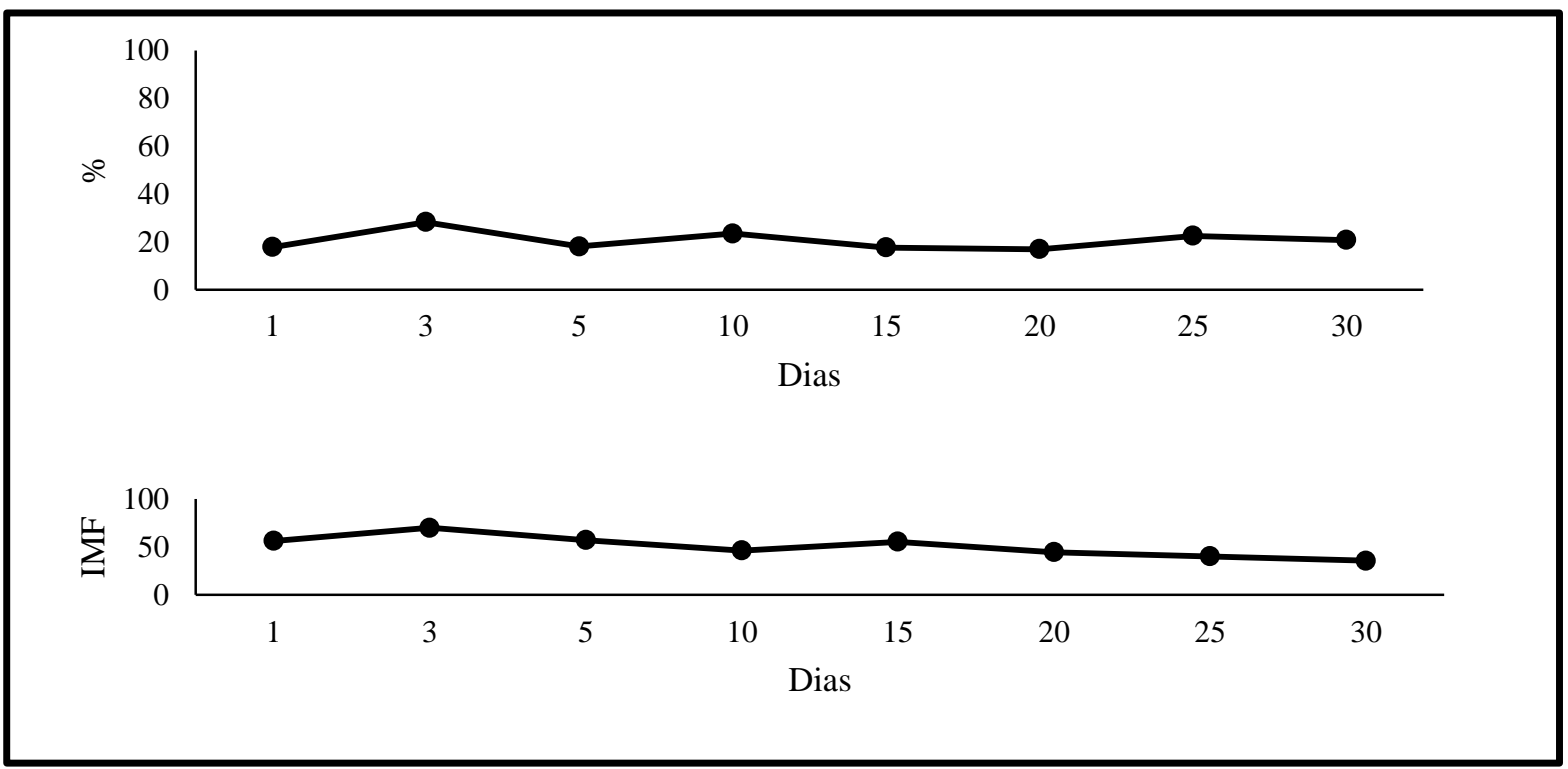

IMF: intensidade média de fluorescência.

Fonte: Shecaira, 2017

$\mathrm{Na}$ avaliação dos ensaios de fagocitose e metabolismo oxidativo, pode-se observar a dinâmica da fagocitose de SaPI pelos granulócitos ao longo dos momentos estudados. Como demonstrado na figura 8, a porcentagem de granulócitos fagocitando SaPI não apresentou diferença ao longo dos tempos avaliados, o mesmo ocorreu para a intensidade desta fagocitose.

Além disso, a análise destes ensaios permitiu a observação de quatro diferentes comportamentos em relação aos granulócitos: (a) células que estavam fagocitando SaPI, mas não estavam produzindo EROs; (b) células que estavam fagocitando SaPI e, também, estavam produzindo EROs; (c) células que não estavam fagocitando SaPI, mas estavam produzindo EROs; e (d) células que não estavam fagocitando SaPI nem produzindo EROs (figuras 9 a $13)$. 
Figura 9 Dinâmica da porcentagem de granulócitos fagocitando Staphylococcus aureus e da intensidade desta fagocitose (IMF), por células que não estavam produzindo espécies reativas de oxigênio, em 20 bezerros da raça Holandesa durante o primeiro mês de vida

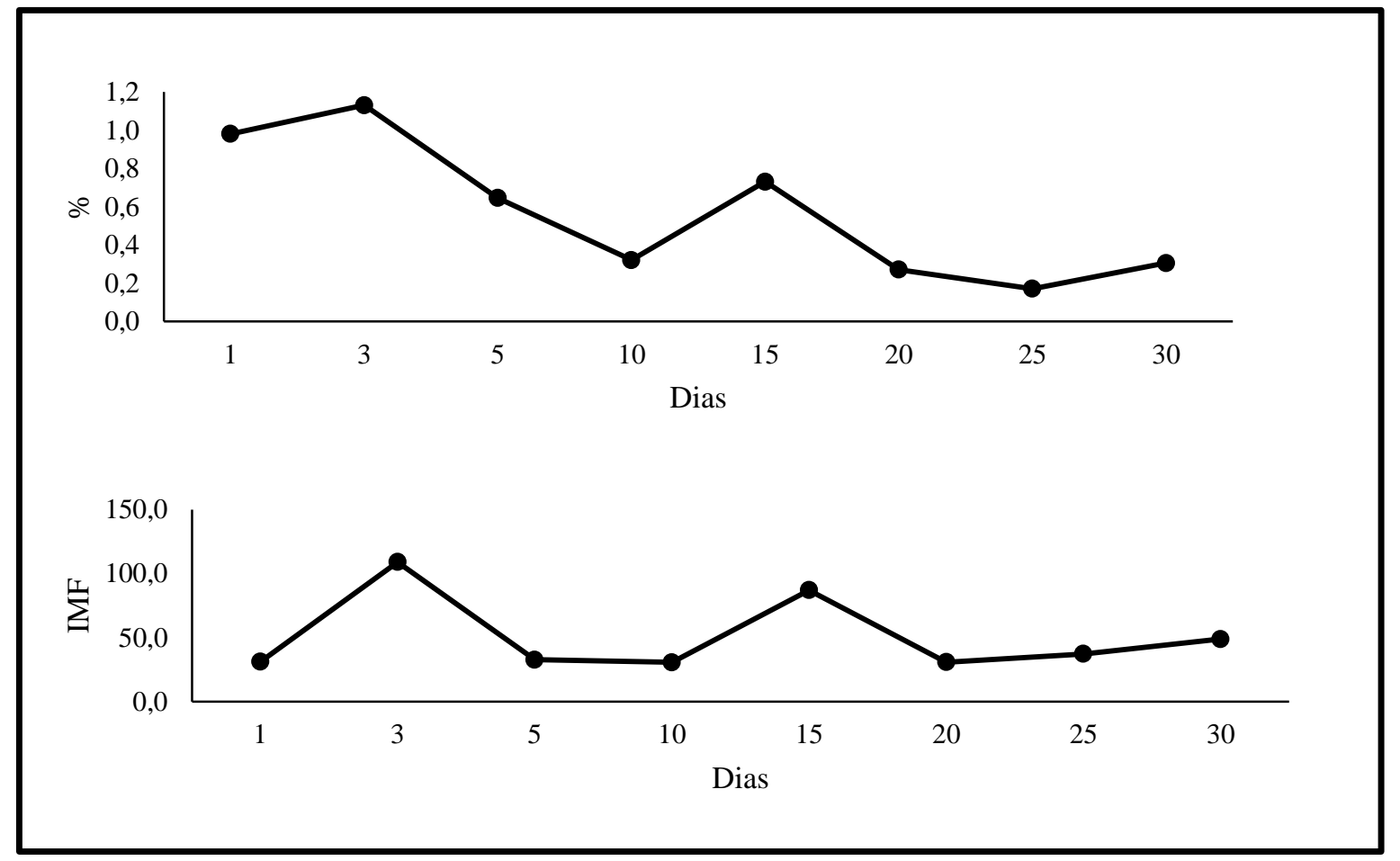

IMF: intensidade média de fluorescência.

Fonte: Shecaira, 2017 
Figura 10 Dinâmica da porcentagem de granulócitos fagocitando Stapylococcus aureus marcados com iodeto de propídio, por células que estavam produzindo espécies reativas de oxigênio, bem como a intensidade da fagocitose (IMF) e a intensidade da produção de espécies reativas de oxigênio IMF), em 20 bezerros da raça Holandesa durante o primeiro mês de vida
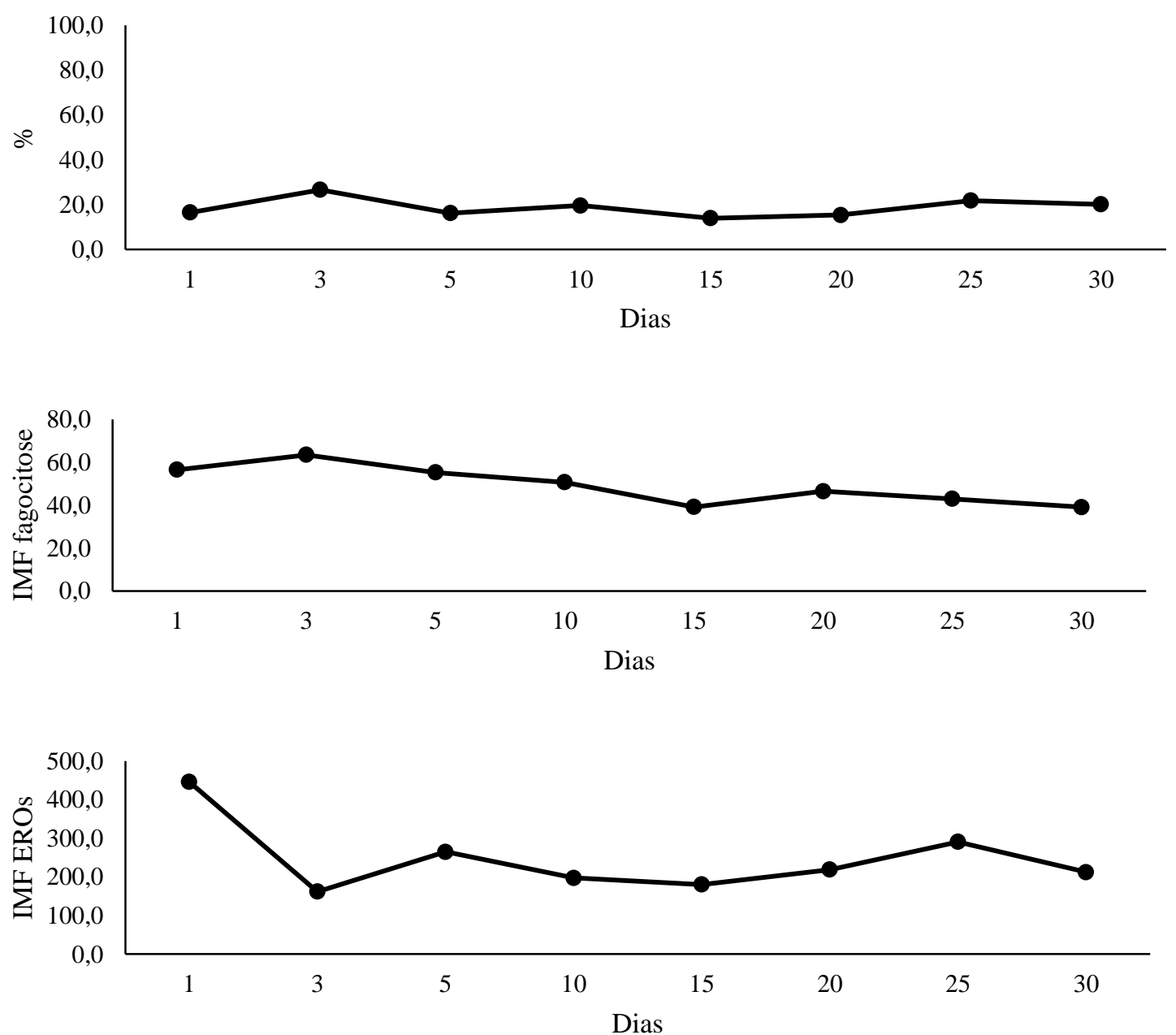

IMF: intensidade média de fluorescência.

Fonte: Shecaira, 2017

Ao avaliar-se a porcentagem de granulócitos que estavam fagocitando SaPI e, também, produzindo espécies reativas de oxigênio, não foi observada diferença ao longo dos tempos. Tal comportamento também foi observado na intensidade desta fagocitose e na intensidade da produção de espécies reativas de oxigênio (figura 10). 
Figura 11 Dinâmica do aumento da intensidade de fagocitose de Stapylococcus aureus marcados com iodeto de propídio, por granulócitos que também estavam produzindo espécies reativas de oxigênio, em relação aos que não estavam produzindo, em 20 bezerros da raça Holanda durante o primeiro mês de vida

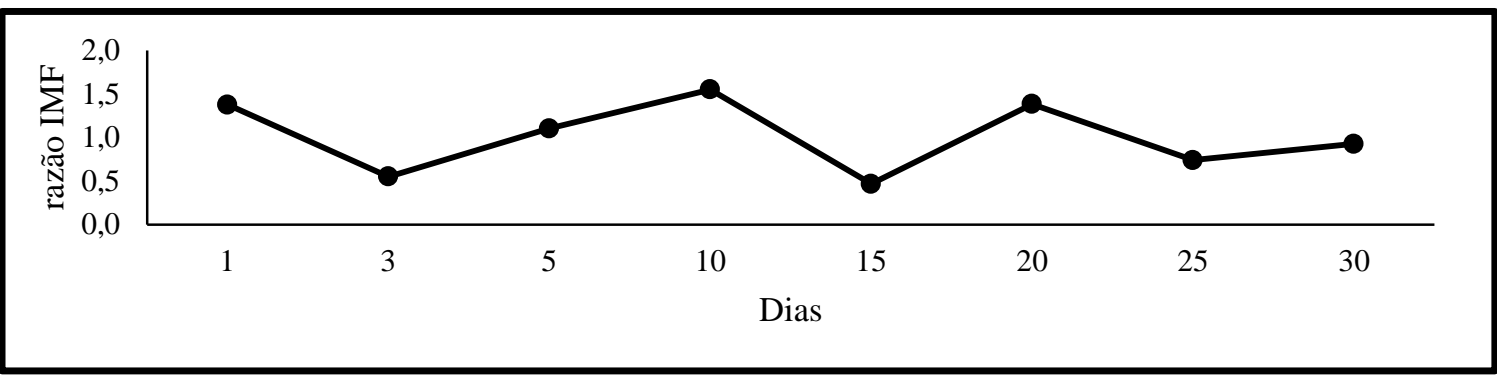

IMF: intensidade média de fluorescência.

Fonte: Shecaira,2017

Não foi demonstrada diferença no aumento da intensidade da fagocitose de SaPI por granulócitos que também estavam produzindo EROs, em relação aqueles que estavam fagocitando SaPI, mas não estavam produzindo EROs, ao longo dos oito tempos estudados, como se observa na figura 11.

Figura 12 Dinâmica da porcentagem de granulócitos produzindo espécies reativas de oxigênio sem fagocitose de Staphylococcus aureus marcados por iodeto de propídio, e intensidade desta produção (IMF), em 20 bezerros da raça Holandesa durante o primeiro mês de vida

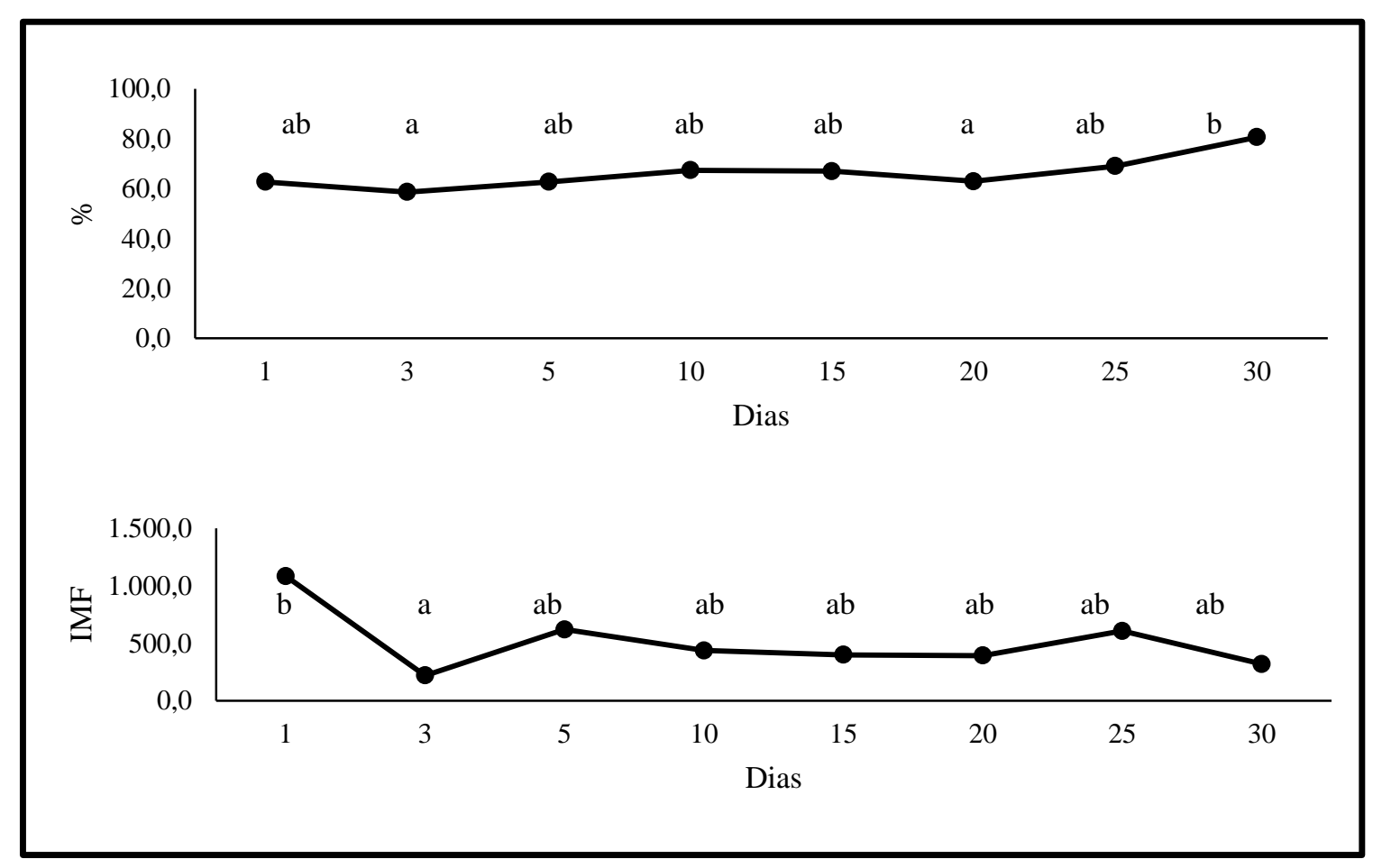

IMF: intensidade média de fluorescência. Letras minúsculas diferentes representam diferença entre os tempos. Fonte: Shecaira,2017. 
Na figura 12, estão dispostas as porcentagens de granulócitos fagocitando SaPI sem produção de EROs, e a intensidade desta fagocitose. Estas duas variáveis analisadas apresentaram diferença ao longo dos dias $(\mathrm{p}=0,008$ e $\mathrm{p}=0,009$, respectivamente). A maior porcentagem desta população de granulócitos foi observada aos 30 dias p.n., enquanto que a maior intensidade desta fagocitose foi visualizada no dia 1 p.n. No dia 3 p.n., observou-se uma diminuição na porcentagem desta população de granulócitos e na intensidade da fagocitose.

Figura 13 Gráfico do aumento da intensidade de produção de EROs (IMF) por granulócitos fagocitando SaPI, em relação aos granulócitos que não estavam fagocitando SaPI, em 20 bezerros da raça Holandesa durante o primeiro mês de vida

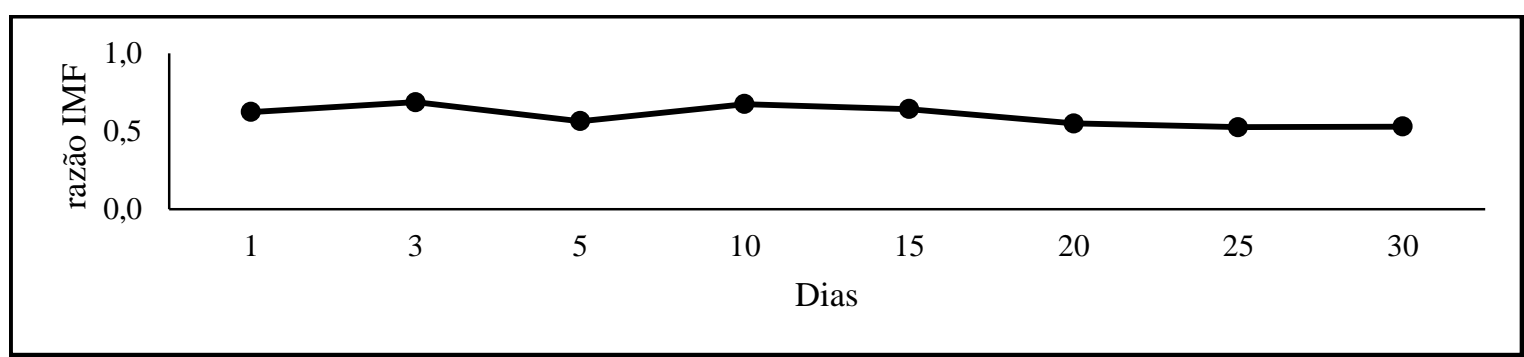

IMF: intensidade média de fluorescência.

Fonte: Shecaira, 2017

A figura 13 mostra o aumento da intensidade de produção de espécies reativas de oxigênio por granulócitos fagocitando SaPI, em relação aos granulócitos que não estavam fagocitando SaPI. No entanto, não foi observada diferença entre os tempos. 
Figura 14 Quantificação das subpopulações de linfócitos T: porcentagem de células $\mathrm{CD3}^{+}, \mathrm{CD4}^{+}, \mathrm{CD8}^{+}$e a razão entre as subpopulações $\mathrm{CD4}^{+} / \mathrm{CD8}^{+}$em 20 bezerros da raça Holandesa durante o primeiro mês de vida

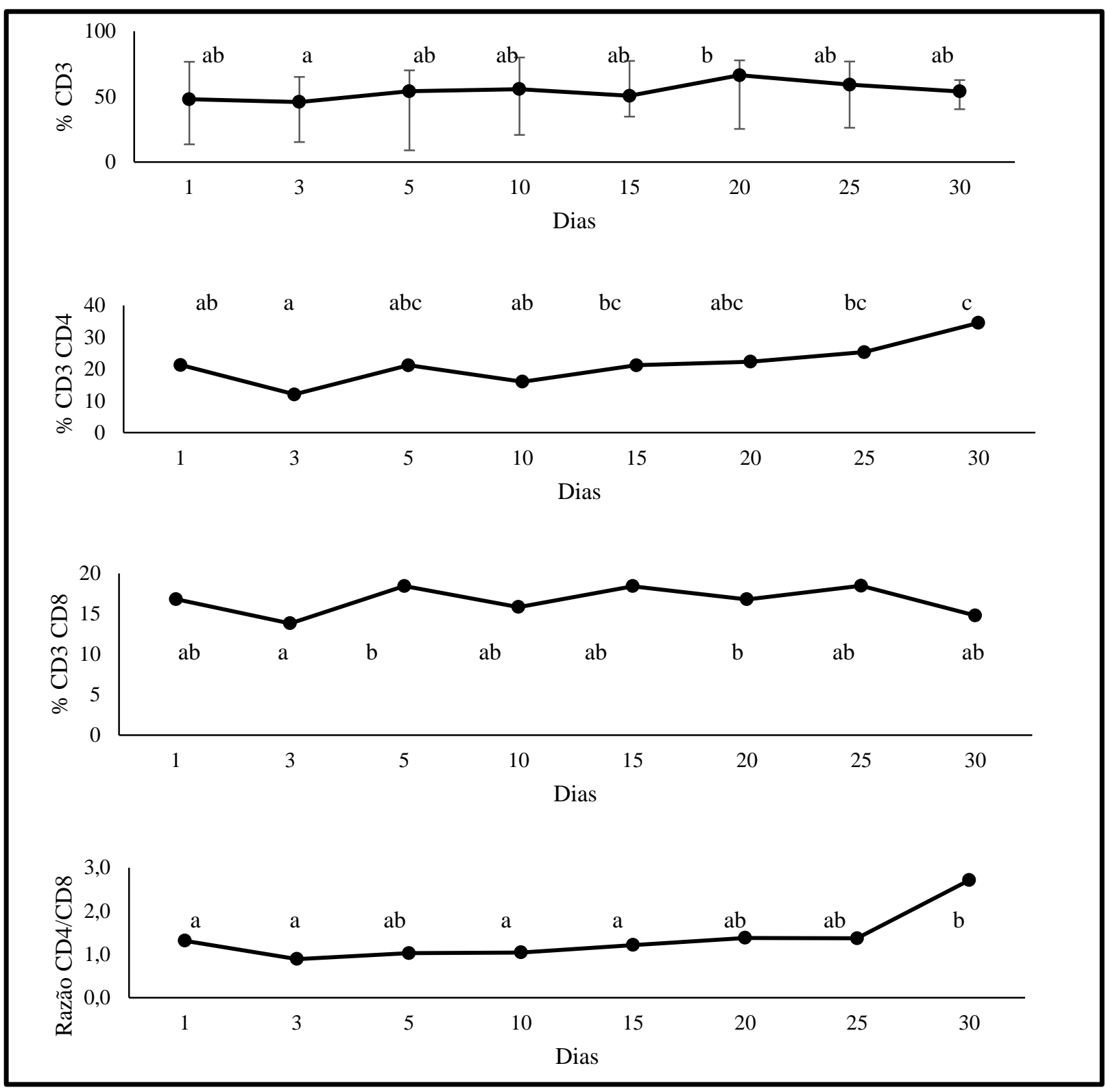

Letras minúsculas diferentes representam diferença entre os tempos.

Fonte: Shecaira,2017.

$\mathrm{Na}$ figura 14 estão dispostas as quantificações de linfócitos $\mathrm{CD}^{+}$, suas subpopulações $\left(\mathrm{CD}^{+} \mathrm{CD}^{+}\right.$e $\left.^{\mathrm{CD}} 3^{+} \mathrm{CD} 8^{+}\right)$e a relação entre linfócitos $\mathrm{CD} 4^{+}$e $\mathrm{CD} 8^{+}$. As quantificações de linfócitos $\mathrm{CD}^{+}, \mathrm{CD}^{+}$e $\mathrm{CD}^{+}$apresentaram diferença ao longo dos tempos estudados $\left(\mathrm{p}=0,014 ; \mathrm{p}<0,001\right.$ e $\mathrm{p}<0,005$, respectivamente). A relação entre linfócitos $\mathrm{CD}^{+}$e $\mathrm{CD} 8^{+}$ também apresentou diferença ao longo dos dias analisados $(\mathrm{p}<0,001)$. A menor porcentagem 
de linfócitos $\mathrm{CD}^{+}$foi observada aos 3 dias p.n.. Os linfócitos do tipo $\mathrm{CD}^{+}$e $\mathrm{CD} 8^{+}$também apresentaram suas menores porcentagens neste dia.

Por sua vez, a maior porcentagem de linfócitos $\mathrm{CD}^{+}$foi observada aos 20 dias p.n., enquanto que, para os linfócitos $\mathrm{CD}^{+} \mathrm{CD}^{+}$, as maiores porcentagens foram nos dias 5, $15 \mathrm{e}$ 25 p.n.. Os linfócitos $\mathrm{CD}^{+} \mathrm{CD} 4+$ apresentaram maiores porcentagens nos dias 25 e 30 p.n.. A contagem absoluta de linfócitos (figura 3) também demonstrou maiores valores nos dias 25 e 30 p.n.

Quanto à relação $\mathrm{CD}^{+} / \mathrm{CD}^{+}$, nos dias 3 e 5 p.n. constatou-se menor relação, havendo, aos 30 dias, a maior relação.

Figura 15 Expressão gênica das citocinas IL-10 e IL-12 por leucócitos de 20 bezerros da raça Holandesa no primeiro mês de vida.

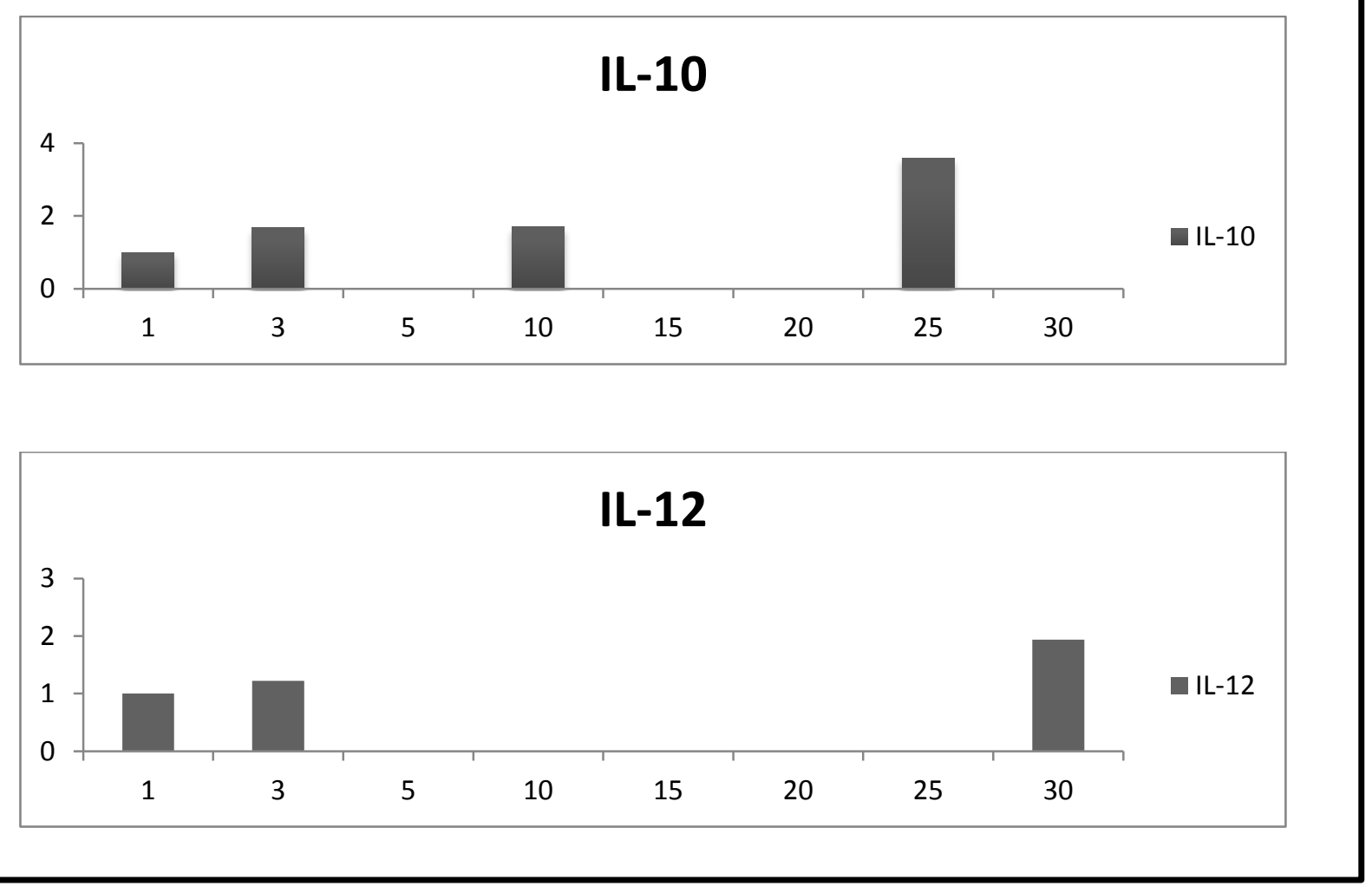

Fonte: Shecaira, 2017

Para a expressão gênica de citocinas IL-10 e IL-12 pelos leucócitos, não se observou diferença ao longo dos dias estudados. Em alguns momentos não foi possível detectar tal expressão pela técnica empregada.

A expressão de interleucina 10 foi detectada nos dias 1; 3; 10 e 25 p.n. Enquanto que a expressão de interleucina 12 foi detectada nos dias 1, 3 e 30 p.n.. 
Ao confrontar os momentos que tais interleucinas foram detectadas pela técnica empregada com a contagem absoluta de leucócitos, pode-se observar que no dia 3 p.n. onde a expressão gênica de inteleucina 10 e 12 foi detectada, os linfócitos apresentaram menores contagens (figura 3). A interleucina-10 teve sua expressão detectada no dia 10 p.n., bem como visualizou-se um aumento na contagem de monócitos e uma diminuição na contagem de granulócitos (figura 3).

No dia 25 p.n., detectou-se a expressão de IL-10 e também observou-se um aumento na contagem de linfócitos. Aos 30 dias p.n., foi possível detectar a expressão da IL-12, momento onde também observa-se um aumento nas contagens de linfócitos, monócitos e granulócitos (figura 3).

Quanto à produção de EROs sem estímulo ou com estímulo, observa-se um aumento das porcentagens de granulócitos produzindo EROs aos 30 dias p.n., onde também se observa a detecção da expressão gênica da citocina IL-12, para a intensidade média de fluorescência de granulócitos produzindo EROs com estímulo por SaPI também se observa um aumento aos 30 dias p.n. (figuras 4 e 5).

Para a produção de espécies reativas de oxigênio sem fagocitose de SaPI, observa-se um decréscimo de porcentagem de granulócitos produzindo EROs e também um decréscimo de intensidade média de fluorescência (figura 12) no dia 3 p.n.. Neste mesmo dia, foi detectada e expressão gênica das citocinas IL-10 e IL-12. No dia 30 p.n., nota-se um aumento de porcentagem de granulócitos produzindo EROs sem fagocitose de SaPI (figura 12), e concomitantemente, a detecção da expressão de IL-12.

Nas quantificações das subpopulações de linfócitos T, aos 3 dias p.n. observa-se uma diminuição das porcentagens de $\mathrm{CD}^{+}, \mathrm{CD}^{+}$e $\mathrm{CD} 8^{+}$, e uma diminuição da relação $\mathrm{CD} 4^{+}$e $\mathrm{CD} 8^{+}$; juntamente com a detecção da expressão das interleucinas 10 e 12 neste dia. No dia 10.p.n., tem-se um aumento da porcentagem de $\mathrm{CD}^{+}$e uma diminuição da relação $\mathrm{CD} 4{ }^{+} \mathrm{e}$ $\mathrm{CD}^{+}$, momento este onde também foi detectada a expressão de IL-10.

As porcentagens de $\mathrm{CD}^{+}$e a relação $\mathrm{CD}^{+}{ }^{+}$e $\mathrm{CD} 8^{+}$tiveram um aumento aos 30 dias p.n., neste dia também foi possível observar a expressão gênica de IL-12. 


\section{DISCUSSÃO}

Cada vez mais têm-se pesquisado acerca do comportamento imunitário dos bezerros em seu período neonatal. No entanto, existem mais pesquisas a respeito da atividade imune do bezerro em condição de doença ou em resposta a estímulos vacinais, sendo a atividade imune do bezerro hígido não muito estudada.

Por ser o período neonatal, um momento onde ocorrem alterações fisiológicas para a adaptação do recém-nascido à vida extrauterina, e por essas mudanças ser considerado um período de transição, o bezerro apresenta-se mais susceptível a doenças, podendo gerar grandes perdas econômicas. Conhecer tais mudanças auxilia a prevenir ou minimizar essas doenças e diminuir os prejuízos que causam

Desta forma, com essa pesquisa avaliou-se a atividade imune de bezerros sadios no seu período neonatal. Para garantir a higidez dos animais durante o período experimental e garantir que esses neonatos tivessem adequada proteção proveniente do colostro, foram realizadas avaliações que comprovassem a transferência de imunidade passiva, e exames físico e complementares (hemogramas seriados) que abrangeram o período experimental.

\subsection{CRITÉRIOS DE INCLUSÃO}

Como o critério de inclusão foi estabelecido a utilização somente de bezerros hígidos, que apresentassem resultados com padrões fisiológicos aos exames físico e laboratorial realizado a cada tempo amostral, foram utilizados apenas animais que tivessem obtido adequada transferência de imunidade passiva mediante a ingestão do colostro, a fim de garantir a ausência de alterações que não fossem fisiológicas.

Deste modo, os três métodos adotados para verificação da qualidade de transferência de imunidade (a concentração sérica de proteínas totais (PT); concentração sérica de globulinas e concentração de gama glutamil transferase). Apresentaram que eram concordantes com os da literatura estudada para caracterizar a adequada transferência de imunidade passiva colostral (RADOSTITS, 2002; SMITH, 2005; HILL, 2010) confirmando assim que os animais incluídos no experimento eram portadores de uma adequada 
transferência de imunidade passiva por meio da ingestão do colostro nos primeiros dias de vida.

\subsection{HEMOGRAMA}

Com o intuito de monitorar a sanidade dos 20 bezerros utilizados durante o período de experimento, realizou-se, além do exame físico geral, e o hemograma nos dias fixados para as colheitas de sangue para os ensaios de citometria de fluxo e PCR em tempo real.

\subsubsection{Eritrograma}

Ao longo dos 30 dias de vida avaliados, os resultados obtidos para o eritrograma dos 20 bezerros estudados, apresentaram aumentos no número de eritrócitos e no CHCM, enquanto que as taxas de hemoglobina e de hematócrito permaneceram estabilizadas. No entanto, se observou diminuição dos valores de VCM e HCM. Quando se comparou os resultados deste trabalho com os obtidos por Benesi e colaboradores (2012a), foi possível verificar semelhança para o comportamento dos números dos eritrócitos, VCM e HCM.

Ao analisar os resultados do eritrograma, expostos nas tabelas 2 e 3 , considerando a evolução etária constata-se que, no dia 1 pós-nascimento, os animais apresentavam menor número de hemácias, no entanto, com maiores volume globular e concentração de hemoglobina. Ao longo dos trinta dias estudados o número de hemácias aumentou, enquanto houve concomitante redução do seu tamanho. Esse comportamento pode decorrer de que ao nascimento os bezerros ainda apresentam certo número de eritrócitos de origem fetal, os quais são maiores, e à medida que vão sofrendo a catérese vão sendo substituídas por eritrócitos produzidos pós-nascimento, que são de menor tamanho, ocorrendo como consequência a diminuição do volume globular e do VCM (JAIN, 1993).

Os dias 1 e 3 p.n. apresentaram os menores valores do número de eritrócitos, em relação aos demais momentos analisados, caracterizando a chamada anemia fisiológica (ADAMS; GARRY; ALDRIBGE 1992; BENESI, 1992) resultante da ingestão inicial de grande volume de colostro que, pela elevada concentração de proteínas, causaria um desvio 
dos líquidos dos meios intracelular e extracelular para os vasos sanguíneos promovendo uma expansão do volume plasmático, promovendo uma hemodiluição (BENESI, 1992).

Neste trabalho, tal como a outros, foi possível notar que houve influência do fator etário nos componentes do eritrograma (BENESI et al., 2012a, BIONDO et al., 1998; FAGLIARI et al., 1998; TÁVORA, 1997; TEIXEIRA, 1999). Apesar das diferenças numéricas encontradas no confronto com os resultados desses autores, todos os componentes do eritrograma no presente estudo estavam dentro do intervalo de variação dos valores fisiológicos de referência do eritrograma bovino, segundo Radostits (2002), corroborando com a higidez desejada dos animais incluídos no estudo.

\subsubsection{Leucograma}

Os resultados das contagens totais de leucócitos apresentaram maior valor mediano no dia 1 p.n., seguido de uma diminuição nos dias 3 e 5 p.n.. Para a contagem do número de linfócitos foram observados valores menores para os dias 1 e 3 p.n., mantendo-se a seguir com discreto e progressivo aumento, até atingirem maiores valores nos dias 25 e 30 p.n. Os resultados encontrados no presente estudo para esses componentes do leucograma foram semelhantes aos encontrados por Benesi e colaboradores (2012b).

O comportamento das variações observadas para contagens totais de leucócitos, de neutrófilos e de linfócitos nos primeiros dias p.n., equiparam-se àqueles sofridos pela ação do aumento dos corticoides endógenos; em consequência do estresse do nascimento (BENESI,1992, EBERHART; PATT, 1971, LA MOTTE; EBERHART, 1976, TENNANT et al.1974).

É reconhecido que sob influência dos corticoides os neutrófilos predominam no leucograma e que nas duas primeiras semanas de vida de bezerros ocorre a inversão da proporção entre neutrófilos e linfócitos, predominando então os linfócitos, tornando-se estas proporções semelhantes àquelas encontradas em bovinos adultos (BENESI, 1992). No entanto, a completa inversão dessa relação não foi observada nos 20 animais analisados. Verificando-se somente uma tendência à inversão da relação Neutrófilos: Linfócitos, não sendo possível determinar a causa da ausência dessa inversão, cogitando-se ser a persistência do estresse a que esses animais estiveram submetidos a possível razão do comportamento. 
Quanto aos monócitos, verificou-se pequenas oscilações no decorrer dos 30 dias de vida avaliados, observando os menores valores aos 3 dias p.n. e os maiores valores nos dias 10, 20 e 30 p.n.. Comportamento semelhante foi descrito por diversos autores, indicando que as variações observadas no número de monócitos seguiram dentro da normalidade (BENESI, 1992; TEIXEIRA, 1999; FAGLIARI et al, 1998; KANEKO; MILLS, 1969).

Ressalta-se que ainda embora os valores de leucócitos totais dos 20 bezerros estudados não teham ultrapassado os valores de referência estabelecidos por Radostits (2002), notou-se que, aos 10 dias p.n., tais animais apresentaram uma mediana de $11,50 \times 10^{3} / \mu \mathrm{L}$, valor este muito próximo ao valor máximo $\left(12 \times 10^{3} / \mu \mathrm{L}\right)$ de referência para normalidade. Apesar das condições higiênico-sanitárias rigorosas adotadas no manejo do biotério onde os animais foram alocados, alguns neonatos apresentaram episódios de diarreia, os quais não causaram grandes complicações à sanidade destes animais. Segundo Benesi (1993) e Radostits (2002), bezerros correm maior risco de morte nas duas primeiras semanas de vida, sendo a asfixia neonatal, a enfermidade entérica e a septicêmica as mais comuns. No entanto, segundo os autores, a qualidade da transferência de imunidade passiva será fator determinante para a evolução mais favorável e regressão do quadro.

Apesar da elevação do número total de leucócitos observada aos 10 dias p.n., os valores encontrados para leucócitos totais neste estudo mantiveram-se dentro dos limites fisiológicos de referencia para o leucograma de bovinos estabelecidos por Benesi et al. (2012b).

\subsection{AVALIAÇÃO DOS GRANULÓCITOS: FAGOCITOSE E METABOLISMO OXIDATIVO}

Define-se por granulócitos, os leucócitos que apresentam abundantes grânulos em seu citoplasma; além de núcleo irregular e multilobulado. Nesta classificação incluem-se os eosinófilos, os basófilos e os neutrófilos, sendo este último tipo, o que compõe o mais numeroso grupo celular dentre os granulócitos, podendo perfazer até $95 \%$ do total destes (ROITT; BROSTOFF e MALE, 2003; TIZARD, 2008).

O papel dos neutrófilos é fundamental na defesa contra infecções bacterianas. Suas funções mais importantes são a fagocitose e a produção de espécies reativas de oxigênio para 
exercer efeito bactericida. Por meio destas atividades, elimina-se o patógeno invasor do sistema orgânico (KAMPEN, et al., 2006).

Diversos autores têm pesquisado a respeito do comportamento de fagocitose e metabolismo oxidativo de granulócitos de bovinos jovens e adultos em ensaios ex vivo, visando compreender tal comportamento diante de diferentes variáveis (KAMPEN et al., 2006; AZEDO, 2007; BATISTA, 2011; GOMES, 2016; COSTA et al., 2017).

Neste estudo, avaliou-se a atividade fagocítica e atividade do metabolismo oxidativo de 20 bezerros Holandeses durante o primeiro mês de vida. Para tal, a produção intracelular de espécies reativas de oxigênio por granulócitos foi avaliada em sua situação basal (sem estímulo ex vivo) e também após estímulo ex vivo pela fagocitose de S. aureus marcados com iodeto de propídio (SaPI).

A técnica utilizada para a avaliação funcional de granulócitos (por meio da atividade fagocítica e mensuração de produção de EROs) foi a citometria de fluxo. Este metódo permitiu avaliar as porcentagens de células realizando fagocitose e/ou produzindo EROs, bem como a intensidade média de fagocitose em células e de produção de EROs. O bom desempenho desta ferramenta de avaliação foi comprovado por Kampen e coautores, em 2004, quando testaram cinco diferentes métodos e consideraram a citometria a técnica mais adequada pela facilidade de execução, necessidade de pequena quantidade de sangue e ter capacidade de isolamento das células de interesse para estudo.

Tais avaliações foram realizadas nas células contidas no gate correspondente aos leucócitos sanguíneos considerando características de tamanho (Foward Scatter Characteristc - FSC) e granulosidade (Side Scatter Characteristc - SSC) condizentes com as esperadas para os granulócitos, confirmadas por intermédio do marcador de superfície específico deste leucócito de bovinos (CH138) (KERESZETES et al., 1996).

Para a avaliação do metabolismo oxidativo dos granulócitos utilizou-se Diacetato de 2,7 Diclorodihidofluresceína (DCFH-DA). Este marcador é capaz de difundir-se no citoplasma, tornando-se um substrato para as EROs produzidas durante tal metabolismo. Como resultado das reações de hidrolise e oxidação do DCFH-DA no citoplasma, forma-se um subproduto, o DCF ou 2,7 Diclorofluoresceína; este composto possui alta capacidade de fluorescência, que refletirá proporcionalmente a atividade do metabolismo oxidativo (AZEDO, 2007; BATISTA, 2011). 


\subsubsection{Porcentagem e intensidade média de fluorescência de granulócitos produzindo espécies reativas de oxigênio (EROs) com e sem estímulo por Staphylococcus aureus marcados com iodeto de propídio (SaPI)}

Ao se comparar a porcentagem de granulócitos produzindo EROs com e sem estimulo, observou-se que os dois grupos de células tiveram comportamento semelhante ao longo dos trinta dias avaliados. Os dois grupos apresentaram maior porcentagem de produção de EROs no primeiro dia p.n.; decréscimo nos dias 15 e 20 p.n. e um aumento desta porcentagem nos dias 25 e 30 p.n.. Mesmo que os dois grupos tenham apresentado diferença entre os momentos estudados, a adição do estímulo com SaPI não alterou a porcentagem de granulócitos produzindo EROs ao longo do primeiro mês de vida dos neonatos.

Aos 30 dias p.n., os ensaios sem e com estímulo dos granulócitos apresentaram a maior porcentagem de células produzindo EROs. Concomitantemente ao fato de que a expressão gênica da citocina IL-12 foi detectada, sendo esta citocina uma das reguladoras do perfil imunitário Th1, indutor de resposta imune celular.

A citocina IL-12 estimula a secreção de interferon-gama (IFN- $\gamma$ ) pelos linfócitos $\mathrm{CD}^{+}$, o qual, induz um aumento da capacidade de fagocitose dos neutrófilos (KOWANKO, 1987, NEWBURGER, 1988; MARCHI, 2010). Apesar de não ter sido observada a expressão gênica de IFN- $\gamma$ nos momentos analisados, não se pode afirmar que não houve produção da mesma, pois a expressão gênica de citocinas pode ter concentrações mínimas além de ser um evento fugaz (ROITT; BROSTOFF e MALE, 2003; TIZARD, 2008; ABBAS; LICHTMAN; PILLAI, 2015).

A presença de produção de EROs sem estímulo verificada no ensaio ex vivo tem sido descrita por diversos autores (AZEDO, 2007; BATISTA et al. 2015; COSTA et al, 2017). Tal fato pode ser fundamentado no estímulo natural que ocorre constantemente in vivo; particularmente no período estudado (neonatal), onde o bezerro tem seu sistema imune sendo desafiado a todo o momento pela presença de microrganismos do ambiente. Além de que os neutrófilos possuem um caráter celular mais ativo, podendo gerar EROs espontaneamente assim como sob estimulo (BURTON, et al., 2005).

No entanto, ressalta-se que o ensaio não estimulado não demonstrou diferença ao longo dos 30 dias de vida, enquanto que o ensaio estimulado apresentou variações na intensidade. Essa diferença entre os ensaios evidencia que os granulócitos foram capazes de 
responder ao estímulo, produzindo variações na intensidade de produção de EROs no decorrer dos dias avaliados.

Quando se comparou os resultados de porcentagem de células produzindo EROs e intensidade de produção de EROs sem estímulo com aqueles obtidos por Costa et al. (2017), em bezerras Holandesas de mesma idade, constatou-se que estes foram divergentes; tais autores observaram maior porcentagem de granulócitos produzindo EROs e com maior intensidade desta produção aos 14 dias de vida, enquanto que neste estudo as maiores porcentagens de granulócitos produzindo EROs foram encontradas aos 30 dias p.n. e os valores verificados para a intensidade de produção de EROs não apresentaram diferença.

Ainda na pesquisa desenvolvida por Costa e colaboradores (2017), os achados para produção de EROs em granulócitos estimulados por SaPI foram diferentes daqueles obtidos no presente estudo. Estes autores afirmaram que a porcentagem de granulócitos produzindo EROs com estimulo permaneceu constante ao longo dos 30 dias p.n. dos neonatos avaliados, enquanto que, neste trabalho, houve diferença entre os tempos observados, apresentando-se com maiores porcentagens nos dias 1, 25 e 30 p.n. e com menores nos dias 15 e 20 p.n..

Para a intensidade desta produção também se encontrou resultados divergentes, visto que Costa et al (2017) não encontraram diferença de intensidade nos 30 dias de vida avaliados para o ensaio com estimulo, ao passo que, nesta pesquisa, houve diferença, com a maior intensidade de produção de EROs observada no primeiro dia 1 p.n., e as menores intensidades nos dias 3, 25 e 30 p.n., tendo os demais dias permanecidos com intensidades constantes.

\subsubsection{Porcentagem e intensidade média de fluorescência induzida pela atividade fagocítica de Staphylococcus aureus marcados com iodeto de propídio (SaPI) realizada por granulócitos com produção de espécies reativas de oxigênio (EROs)}

Para o ensaio de fagocitose ex vivo utilizou-se a bactéria Gram positiva $S$. aureus, sinalizada com o marcador nuclear iodeto de propídio em protocolo anteriormente descrito no item 4 de "material e métodos". Após a internalização das bactérias por intermédio da fagocitose, o iodeto de propídio funciona como um "guia", evidenciando as células responsáveis, por meio de sua fluorescência observada no citômetro de fluxo.

Quando se avaliou a porcentagem de granulócitos fagocitando SaPI, a intensidade desta fagocitose e a aquela de produção de EROs por estas células não se observou diferença 
ao longo dos tempos analisados para nenhuma das variáveis. A média geral dos 30 dias p.n. para a porcentagem de granulócitos que estavam fagocitando as bactérias marcadas, foi de 18,56\%, com uma média geral de intensidade de 47,70 e média geral de intensidade de produção de EROs de 229,40.

Comparando os resultados da porcentagem de fagocitose do presente estudo em relação, com aqueles de outros trabalhos realizados, notou-se que houve divergência com os resultados encontrados por Batista et al. (2015). Esses autores observaram maiores porcentagens de células realizando fagocitose nas primeiras semanas de vida, enquanto no presente trabalho não se observou diferença entre os tempos analisados. Por sua vez, Gomes (2016), semelhantemente ao comportamento encontrado neste estudo, não verificou diferenças entre as porcentagens de fagocitose em bezerros até 57 dias em seu grupo controle.

Os protocolos de marcação de bactérias, o aparelho de citometria, a raça dos animais utilizados e o local onde os bezerros foram alocados foram os mesmos utilizados por Batista et al. (2015), por Gomes (2016) e neste estudo, todavia, deve se considerar as variações genéticas e imunológicas dos animais; além do manejo sanitário adotado em cada propriedade de origem destes animais.

Em relação à intensidade de fagocitose, os resultados obtidos divergiram daqueles encontrados por Batista et al. (2015) que, ao avaliar o sistema imune inato de bezerros da raça Holandesa durante os primeiros três meses de vida, observaram maior intensidade de fagocitose na primeira semana de vida destes animais. Costa et al. (2017) também encontraram maior intensidade de fagocitose nas primeiras duas semanas de vida. Contudo, Gomes (2016) encontrou resultados semelhantes aos deste trabalho, não verificando diferença na intensidade de fagocitose por granulócitos de bezerros nos primeiros três meses de vida. Merece destaque que os animais utilizados por Gomes (2016), em seu grupo controle, eram provenientes da mesma propriedade que os animais utilizados no presente estudo.

Diversos autores apontam uma menor capacidade dos neutrófilos em responder a estímulos em animais mais jovens (HAUSER et al. 1986, PEIXOTO et al. 2002, COSTA et al. 2004). Neste contexto, Peixoto e coautores (2002) observaram menor capacidade oxidativa de neutrófilos de bezerros no período neonatal (primeiro mês de vida) quando os comparou com aquela de bezerros mais velhos (30-90 dias de idade). Essa redução da capacidade dos neutrófilos apontada em bezerros mais jovens pode aumentar o risco de doenças, todavia, uma vez realizada adequadamente a transferência de imunidade passiva via colostro, os neonatos ficarão protegidos por intermédio dos componentes imunitários recebidos neste período de maior vulnerabilidade (HAUSER et al., 1986). 
Alguns estudos têm demonstrado que o interferon-gama estimula a transdução de sinal em neutrófilos, regulando as expressões de genes e de citocinas, além da secreção de $\mathrm{H}_{2} \mathrm{O}_{2}$, em resposta a diversos estímulos (KOWANKO, 1987, NEWBURGER, 1988). Promove desta forma, um aumento da ação microbicida de neutrófilos e macrófagos, e adicionalmente estimula a síntese de intermediários reativos de oxigênio e do óxido nítrico (MARCHI, 2010).

Na presente pesquisa também se avaliou a expressão gênica da citocina interferongama, no entanto a expressão gênica de INF- $\gamma$ foi encontrada em pequena porcentagem de animais em alguns dos tempos avaliados. Tal porcentagem foi insuficiente para permitir uma análise estatística. Desta forma, pode-se inferir que os resultados constantes da avaliação da capacidade de fagocitose dos neutrófilos e de produção de EROs podem ter sido influenciados por concentrações não detectáveis de INF- $\gamma$ pelo método de quantificação ao longo do primeiro mês de vida.

Similarmente a tais resultados obtidos, diversos autores descreveram que no bezerro neonato, alguns mecanismos de imunidade inata se encontram diminuídos, tais como: a atividade de complemento, atividade de neutrófilos e macrófagos, função das células NK e das células dendríticas e produção de interferon (MENGE, et al, 1998; FIRTH; SHEWEN; HODGINS, 2005).

\subsubsection{Porcentagem e intensidade média de fluorescência da produção espécies reativas de oxigênio (EROs) em granulócitos que não estavam fagocitando Staphylococcus aureus marcados com iodeto de propídio (SaPI)}

Registra-se neste estudo uma porcentagem de granulócitos que estavam produzindo EROs sem estarem fagocitando SaPI, tendo o menor valor aos 3 dias p.n. (mediana de $58,62 \%$ ) e maior magnitude aos 30 dias p.n. (mediana de 80,57\%). Quanto à intensidade desta produção, foi observada diferença apenas no dia 1 p.n., no qual esta foi máxima. Merece destaque, em concomitância que, no dia 3 p.n. também se observou a presença de expressão gênica das citocinas IL-10 e IL-12 e que numericamente, a expressão de IL-10 foi maior que a aquela de IL-12. É reconhecido que a interleucina-10 possui caráter anti-inflamatório, polarizando o perfil de resposta Th2 ou humoral. Possivelmente por sua influência, obteve-se 
menor porcentagem de granulócitos produzindo EROs neste momento em relação aos demais tempos.

Por sua vez, no dia 30 p.n., detectou-se a expressão de IL-12, momento em que também se observou a maior porcentagem de granulócitos produzindo EROs. Importante destacar que a interleucina-12 induz à diferenciação de células $\mathrm{T}$ naive em um perfil Th1 quando há um estimulo por antígeno. Após essa polarização (KIDD, 2003), há secreção de interferon-gama pelos linfócitos $\mathrm{CD}^{+}$e esta citocina induz produção de espécies reativas de oxigênio (KOWANKO, 1987, NEWBURGER, 1988). No entanto, neste estudo não foi possível detectar a expressão gênica de interferon-gama em nenhum dos momentos avaliados.

A ocorrência de grande porcentagem de granulócitos produzindo EROs sem indução de fagocitose por SaPI pode estar ligada ao fato de que os neutrófilos são estimulados por diversos elementos como partículas opsonizadas, mediadores inflamatórios, componentes do sistema complemento, imunocomplexos, além de estímulos quimiotáticos (MARCHI, 2010). Como o período neonatal é um período de intenso "reconhecimento imunológico" do ambiente, e os animais não estavam alocados em que fosse germ free, é possível encontrar-se células ativadas além daquelas que receberam o estímulo ex vivo.

\subsection{FENOTIPAGEM DOS LINFÓCITOS T}

Os linfócitos são originados de células tronco indiferenciadas da medula óssea que, ainda na gestação, migram para o timo, onde se diferenciam em linfócitos T (BARRINGTON; PARISH, 2001, GARFIAS, 2011).

Durante o processo de diferenciação, há a expressão de um receptor de células $\mathrm{T}$ (TCR) e dos co-receptores CD4 ou CD8. Para que haja o reconhecimento de antígenos, estes devem ser processados e apresentados por moléculas do MHC (complexo principal de histocompatibilidade) na superfície de uma célula apresentadora de antígeno. O receptor TCR atua reconhecendo o complexo peptídeo-molécula de MHC (MESQUITA JUNIOR et al., 2010; ABBAS; LICHTMA; PILAI, 2012) enquanto que o complexo CD3 promove a sinalização celular subsequente.

No feto bovino os linfócitos podem ser detectados na circulação já aos 45 dias de gestação (TIZARD, 2008). No entanto, aproximadamente um mês antes do nascimento, há uma redução drástica dos linfócitos T no sangue periférico. Neste intervalo, os linfócitos 
migram e povoam os tecidos linfoides do feto (BARRINGTON; PARISH, 2001, CHASE; HURLEY; REBER, 2008).

As células $\mathrm{T} \mathrm{CD}^{+}$representam entre $28 \%$ e $34 \%$ do total de linfócitos no bezerro neonato. Aproximadamente $20 \%$ são células T são $\mathrm{CD}^{+} \mathrm{CD}^{+}$e $10 \%$ são $\mathrm{CD}^{+} \mathrm{CD}^{+}$; tais proporções são semelhantes àquelas encontradas no bovino adulto (CHASE; HURLEY; REBER, 2008).

Os linfócitos $\mathrm{T} \mathrm{CD}^{+}$, chamados auxiliares, atuam reconhecendo antígenos processados (STEVENS \& LOWE, 2001; SUETAKE et al., 2006) e possuem receptor para moléculas de $\mathrm{MCH}$ tipo II, presentes nas superfícies de células apresentadoras de antígenos. Ativam a resposta imune, por meio da secreção de citocinas, induzindo outras células a realizarem funções efetoras (FURTADO, 2006; SUETAKE et al.,2006; WIKSTRÖM, 2006).

Os linfócitos $\mathrm{T} \mathrm{CD}^{+}$são denominados citotóxicos. Reconhecem antígenos não processados, que são apresentados por meio de células em associação com moléculas de MHC tipo I (SUETAKE et al., 2006), e agem atacando e lisando as células alvo (STEVENS \& LOWE, 2001; FURTADO, 2006; WIKSTRÖM, 2006).

Cada subpopulação de linfócitos $\mathrm{T}$ produz um perfil distinto de citocinas. Assim, enquanto que linfócitos $\mathrm{CD}^{+}{ }^{+}$secretam citocinas como IL-2, IL-4, IL-5 e IFN-gama, os linfócitos CD8+ secretam IFN, TNF-alfa e IL-12, que induzem a lise das células alvo no intuito de erradicar a infecção (ABDALLA et al. 2003; TANAKA et al., 2007).

A compreensão do sistema imune do bovino tem avançado de forma significativa nos últimos anos, com o advento da produção dos anticorpos monoclonais para a identificação das várias subpopulações de linfócitos (AYOUB; YANG, 1996). Neste trabalho realizou-se a quantificação dos linfócitos $\mathrm{T}\left(\mathrm{CD}^{+}\right)$e suas subpopulações $\left(\mathrm{CD} 4^{+}\right.$e $\left.\mathrm{CD} 8^{+}\right)$obtidos do sangue de 20 bezerros da raça Holandesa, nos primeiros 30 dias de vida, em oito momentos, estudados por meio da citometria de fluxo.

Os resultados registrados para os valores de linfócitos $\mathrm{CD}^{+}$e suas subpopulações $\left(\mathrm{CD}^{+} \mathrm{e} \mathrm{CD}^{+}\right)$apresentaram uma média maior em relação à porcentagem de $\mathrm{CD}^{+}(53,90 \%$ das células contidas no gate), uma média de $\mathrm{CD}^{+} \mathrm{CD}^{+}$de $16,73 \%$ e uma média de $\mathrm{CD}^{+} \mathrm{CD}^{+}$de $21,28 \%$, considerados os 30 dias avaliados. Tais resultados observados no presente estudo foram semelhantes aos encontrados por Ayoub; Yang (1996) e Kampen et al. (2006).

Segundo Laidlaw e coautores (2015), a produção de IL-10 promove o desenvolvimento de células do fenpotipo $\mathrm{CD}^{+}$de memória no momento de resolução de infecções virais em camundongos. No presente trabalho, detectou-se a expressão gênica da 
IL-10 nos dias 3, 10 e 25 p.n., além do dia controle (primeiro dia p.n.), no entanto não foi possível observar um aumento de linfócitos $\mathrm{CD} 8^{+}$nestes dias, apenas uma tendência numérica de aumento do $\mathrm{CD}^{+}$aos 25 dias de vida. Ressalta-se que este estudo foi realizado em bezerros hígidos e assim sendo, sem estímulos antigênicos de maior monta, não foi possível comprovar a influência de IL-10 sobre a quantidade de linfócitos $\mathrm{CD}^{+}$.

Aos 30 dias p.n., foi evidenciada a maior relação $\mathrm{CD}^{+} / \mathrm{CD}^{+}(2,71)$, resultado do aumento de linfócitos $\mathrm{CD}^{+}$. Simultaneamente, observou-se a expressão gênica de IL-12. Knuston e Disis (2004), ao estudarem a influência da IL-12 sobre a ação de células T CD4 ${ }^{+}$ em antígenos tumorais ex vivo, demonstraram que a administração de IL-12 e de IL-2 à cultura celular de $\mathrm{CD}^{+}$aumentou sua proliferação e resposta aos antígenos tumorais, com polarização de resposta do tipo Th1. Adicionalmente, no dia 30 p.n.com o aumento da relação $\mathrm{CD}^{+} / \mathrm{CD}^{+}$e a detecção gênica de IL-12, também foram observados aumento de leucócitos totais, monócitos e granulócitos, e um aumento da produção de EROs pelos granulócitos, sugerindo que neste momento foi possível identificar uma polarização de resposta imune do tipo Th1.

Assim como observado em outros trabalhos (AYOUB; YANG, 1996; KAMPEN et al, 2006; CHASE; HURLEY; REBER, 2008, OHTSUKA et al., 2014), no presente estudo demonstrou-se porcentagens de linfócitos $\mathrm{T} \mathrm{CD}^{+} \mathrm{CD}^{+}$e $\mathrm{CD}^{+}$semelhantes àquelas aos encontradas em bovinos adultos. Apesar dos bezerros apresentarem semelhança percentual de linfócitos $\mathrm{T}$ a exposição de células $\mathrm{T}$ de recém-nascidos a antígenos resulta em uma menor produção de IFN- $\gamma$ e outras citocinas, quando comparadas as células T maduras (TIZARD, 2008).

Também foi observado um aumento da população de $\mathrm{CD}^{+}$com a evolução etária, determinado pelo aumento da subpopulação CD4 ${ }^{+}$. Kampen e coautores (2006), similarmente, observaram um aumento no número absoluto de linfócitos CD4 com o evoluir da idade e o atribuíram à diminuição dos valores relativos de linfócitos $\gamma \delta$. Porém, neste trabalho, não foram avaliados as populações de linfócitos $\gamma \delta$ não sendo possível demonstrar a razão do comportamento presenciado. 
5.5. EXPRESSÃO GÊNICA DE CITOCINAS IL-14, IL-10, IL-12 E IFN- $\gamma$ DE LEUCÓCITOS SANGUÍNEOS

As citocinas desempenham um importante papel relacionado à polarização de perfil de resposta imunitária Th1/Th2. Cada vez mais, tem sido estudada a expressão gênica de citocinas em bovinos visando observar o comportamento destas em infecções parasitárias (CANALS et al., 1997; CLAREABOUT et al., 2005; MEEUSEN; BALLIC; BOLWLES, 2005; IBELLI, 2008; ALMERIA et al., 2012), em resposta a doenças (BERTAGNON, 2014; BATISTA et al., 2015) e resposta para a comprovação de efetividade de vacinas (MENA et al., 2002; ANTONIS et al., 2010; GOMES, 2016).

No entanto, são escassos (OHTSUKA et al., 2014; GRELL et al., 2005) estudos a respeito do comportamento das citocinas em condições basais em bezerros neonatos sadios no primeiro mês de vida.

Para os bovinos não existem grande quantidade de ensaios para a detecção de citocinas como em humanos ou camundongos (MENA et al., 2002; HOLMGREN, et al. 2014). Deste modo, optou-se pela técnica de PCR em tempo real, por ser uma técnica sensível (DENG; LI; TANG, 2003; KONNAI et al., 2003; PUECH et al., 2015) e que tem sido utilizada frequentemente para pesquisar expressão gênica de citocinas em bovinos (MENA, et al., 2002; INGALE, et al., 2008; ANTONIS et al, 2010; IBELLI, 2010; ALMERIA et al., 2012; LEACH et al., 2012; BERTANGON, 2014; GONZÁLEZ-CANO et al., 2014; HOLMGREN et al., 2014; BATISTA, 2015; GOMES, 2016).

Neste trabalho analisou-se o comportamento de quatro citocinas (IL-4, IL-10, IL-12 e IFN- $\gamma$ ) em bezerros durante os primeiros 30 dias p.n., em condições imunitárias basais, considerando-se que as citocinas IL-12 e IFN- $\gamma$ estão envolvidas com a determinação de perfil tipo Th1 enquanto que as citocinas IL-4 e IL-10 induzem o perfil imunológico tipo Th2.

Nos 20 bezerros estudados ao longo dos primeiros 30 dias p.n., não foi possível detectar expressão gênica da interleucina-4. Somente em uma pequena porcentagem de animais apresentou-se a expressão gênica de tal citocina, não podendo-se assim realizar uma análise estatística sobre o comportamento de variação da mesma.

A IL-4 possui a capacidade de conferir proteção e resistência a uma gama de infecções causadas por parasitas (ELSE; FINKELMAN, 1998, CLAREABOUT et al., 2005, CRAIG et al., 2007). Em bovinos, observa-se um aumento de citocinas de perfil Th2, especialmente IL-4, frente a endoparasitas gastrointestinais, conferindo-lhes respostas 
protetoras (ELSE; FINKELMAN, 1998, GRENCIS, 2001, MEEUSEN; BALLIC; BOLWLES, 2005). No entanto, a interleucina-4 é produzida principalmente por eosinófilos e basófilos (VOERINGER; SHINKAI; LOCKSLEY, 2004), que são tipos leucocitários presentes em pequenas quantidades em condições imunitárias basais em bovinos. Assim sendo, possivelmente, a concentração desta interleucina em animais sadios seja mínima, e não detectável pela técnica utilizada (BERTAGNON, 2014; HOLMGREN et al., 2014; INGALE et al., 2008).

Semelhantemente aos resultados encontrados neste estudo, Grell e colaboradores (2005) não evidenciaram expressão gênica de citocinas IL-4 nos bezerros com até um mês de vida, utilizados em um grupo controle da pesquisa. A expressão de IL-4 em contraposição foi detectada em pesquisas onde os leucócitos foram estimulados por lecitinas como a ConA (Concanavalina A) ou PHA (fitohemaglutinina de Phaseolus vulgaris) (MENA et al., 2002, OHTSUKA et al., 2014). Todavia, o intuito desta pesquisa era detectar expressão de citocinas em situação basal, e, portanto, tal estímulo não foi realizado.

Quanto à interleucina-10, pode-se detectar sua expressão nos dias 3, 10 e 25 p.n., além do dia 1 (controle). No entanto, não apresentaram diferenças entre os tempos. Apesar de não ter sido encontrada diferença entre os tempos, numericamente se observou um aumento de expressão com a evolução etária. De forma similar, Ohtsuka et al. (2014) verificaram um aumento da expressão de IL-10 ao longo do primeiro mês de vida de bezerros.

No dia 10 p.n. verificou-se juntamente com a expressão de IL-10, um aumento dos leucócitos totais $\left(11,50 \times 10^{3} / \mu \mathrm{L}\right)$. A citocina IL-10 tem caráter anti-inflamatório, tendo como função diminuir a atividade das células T, NK, macrófagos e neutrófilos (KIDD, 2003; HOUEK et al., 2008; ROJAS, et al., 2017). Supõe-se que a detecção de tal citocina em momento onde há um aumento de leucócitos esteja relacionada à regulação da resposta inflamatória, impedindo que esta tenha um efeito exacerbado, prevenindo danos ao organismo.

Deve-se considerar ainda que a IL-10 pode ser produzida por linfócitos B e linfócitos $\mathrm{CD}^{+}$, e atua favorecendo o perfil do tipo Th2 (LAIDLAW et al., 2015; ROJAS et al., 2017). No dia 25 p.n., juntamente com a expressão gênica de IL-10, verificou-se um aumento de linfócitos no leucograma, enquanto que os valores de leucócitos totais, granulócitos e monócitos se apresentaram estáveis. Além disso, observou-se maior variação numérica da subpopulação de linfócitos $\mathrm{CD} 8^{+}$.

Para a verificação de expressão gênica das citocinas de perfil Th1 analisadas neste estudo, obteve-se: expressão gênica da citocina IL-12 nos tempos 3 e 30 dias p.n., bem como 
no dia 1 p.n. (controle). Contudo, a expressão gênica observada não apresentou diferença entre os momentos estudados.

No dia 30 p.n., evidenciou-se, juntamente com a expressão gênica de IL-12, um aumento na contagem total de leucócitos, com aumento de monócitos e de granulócitos e de produção de espécies reativas de oxigênio pelos granulócitos. A interleucina-12 está envolvida com a proteção do organismo contra infecções bacterianas e virais, promovendo a morte desses microrganismos (JANEWAY). Tal citocina é produzida por todas as células apresentadoras de antígenos, assim como macrófagos e monócitos (KIDD, 2003; ABBAS; LICHTMAN; PILLAI, 2012). Possivelmente, neste dia, alguns animais estavam em um processo infeccioso inicial, contudo, como este foi o último momento analisado não pode-se confirmar tal suposição.

A expressão da citocina IFN- $\gamma$ não apresentou porcentagem de animais suficiente para a análise estatística. Tal resultado discorda dos resultados observados por Grell e coautores (2005), que encontraram expressão de IFN- $\gamma$ mesmo nos bezerros com até um mês de vida do seu grupo controle.

O interferon-gama promove aumento de expressão de moléculas de MHC e de componentes de processamento de antígeno, mudanças de classes de imunoglobulinas, além de supressão das citocinas de perfil Th2. Deste modo, também confere resistência a infecções virais e bacterianas (KIDD, 2003, JANEWAY, 2007). No entanto, com a ausência de infecções naturais ou induzidas, acredita-se que as expressões desta citocina possam ter sido baixas e, desta forma, não terem sido detectadas pela técnica de PCR em tempo real utilizada para verificar sua expressão.

Considerando os resultados obtidos neste estudo, em alguns momentos, não foi possível detectar apenas um perfil de resposta imunitária, Th1 ou Th2, tendo em vista que ao longo dos 30 dias p.n. dos bezerros neonatos foi observada a expressão gênica de citocina IL12 (perfil Th1) e citocina IL-10 (perfil Th2), incluindo os tempos 1 (controle) e aos 3 dias p.n., concomitantemente. Concordando com este resultado, Almeria et al. (2012) também encontrou expressão concomitante de citocinas de perfis diferentes em vacas prenhes infectadas com Neospora caninum, quando se observou a expressão de citocinas IL-12, IFN- $\gamma$ e IL-10, indicando que possa haver momentos onde não há um padrão único de resposta, mas sim um equilíbrio entre as duas, com vistas a modulação da resposta imune.

A ausência de detecção das citocinas IL-4 e IFN- $\gamma$ dificultou a afirmação da existência de um ou de outro perfil de resposta imune (celular ou humoral). No entanto, a interleucina-10 foi encontrada em quatro momentos enquanto que interleucina-12 somente em 
três momentos. Ressalta-se que não são apenas as quatro citocinas retro mencionadas e estudadas que regulam a polarização da resposta imune. Existe uma gama numerosa de citocinas envolvidas com tal resposta, porém neste estudo, só se estudou o comportamento da IL-4, IL-10, IL-12 e IFN- $\gamma$. Todavia, o fato da expressão gênica de IL-10 ter sido mais frequente que a IL-12 tendo uma variação numérica crescente, permite sugerir-se que no período neonatal os bezerros apresentam uma inclinação ou tendência para o perfil Th2.

Canals et al. (1997) em estudo sobre o perfil de citocinas induzido por infecção primária com Ostertagia ostertagi em bovinos, sugere que, em bovinos, o paradigma Th1/Th2 pode não ser tão claramente delineado como no modelo de estudo com ratos. 


\section{CONCLUSÕES}

Com base nos resultados obtidos nesta pesquisa para avaliação de fagocitose e metabolismo oxidativo de neutrófilos, quantificação das subpopulações de linfócitos T e expressão gênica de citocinas, pode se concluir que:

A atividade de fagocitose dos granulócitos foi constante nos 30 dias avaliados;

A produção de espécies reativas de oxigênio por granulócitos foi observada em ensaio basal e por ensaio estimulado, com comportamento semelhante, apresentando os dois ensaios, maiores porcentagens aos dias 1, 25 e 30 p.n.

Os linfócitos $\mathrm{CD}^{+}$e suas subpopulações: $\mathrm{CD} 4^{+}, \mathrm{CD}^{+}$, possuem porcentagens semelhantes aos adultos;

Os linfócitos CD3 apresentaram a menor porcentagem aos 3 dias p.n., com as maiores porcentagens aos 20 dias p.n., permanecendo constantes nos demais dias;

A relação $\mathrm{CD}^{+} / \mathrm{CD}^{+}$foi máxima aos 30 dias de vida, pelo aumento de $\mathrm{CD} 4^{+}$e diminuição de $\mathrm{CD}^{+}$;

Não foi possível mensurar a expressão gênica das citocinas Il-4 e IFN- $\gamma$ em nenhum dos momentos avaliados;

Foi verificada a expressão gênica de citocinas IL-10 e IL-12, com uma inclinação para o perfil Th2 induzido pela expressão de IL-10 mais frequente.

Observou-se a influência da expressão gênica das citocinas IL-10 e IL-12 no leucograma, na atividade dos granulócitos e nas subpopulações de linfócitos T nos dias 1, 3,10, 25 e 30 p.n.. 


\section{REFERÊNCIAS}

ABBAS, A. K.; LICHTMAN, A. H.; PILLAI, S. Imunologia celular e molecular. 7. ed. Rio de Janeiro: Elsevier, 2012.

ABDALLA, O. A.; KIAII, S.; HANSSON, L.; ROSSMANN, E. D.; JEDDI-TEHRANI, M.;SHOKRI, F.; ÖDTERBOG, A.; MELLSEDT, H.; RABBANI, H.. Kinetics of cytokine gene expression in human CD4 and CD8 T-lymphocyte subsets using quantitative real-time PCR. Scandinavian Journal of Immunology. V. 58, n.6, p. 601-606. 2003.

ADAMS R., GARRY F. B.; ALDRIBGE B. M. 1992 Haematologic values in newborn beef calves. American Journal of Veterinary Research. 53(6): 944-50.

ALBERTS, B.; JOHNSON, A.; LEWIS, J.; RAFF, M.; ROBERTS, K.; WALTER, P. Molecular biology of the cell. $4^{\circ}$ ed. New York: Garland. 2002; 1616p.

ALMERÍA, S.; SERRANO, B.; YÀNIZ, J. L.; DARWICH, L.; LÓPEZ-GATIUS, F. Cytokine gene expression profiles in peripheral blood mononuclear cells from Neospora caninum naturally infected dams throughout gestation. Veterinary Parasitology, v. 183, n. 34, p. 237-43, 10 fev. 2012.

ANTONIS, A. F. G.; DE JONG, M. C.; VAN DERPOEL, W.H.M.; VAN DER MOST, R. G.; STOCKHOFE-ZURWIEDEN, D.; KIMMAN, T.; SCHRIJVER, R.S.. Age-dependent differences in the pathogenesis of bovine respiratory syncytial virus infections related to the development of natural immunocompetence. The Journal of General Virology, v.91 n. 10, p 2497-2506. 2010.

AYOUB, I. A.; YANG, T. J.. Age-dependent changes in peripheral blood lymphocyte subpopulations in cattle: a longitudinal study. Developmental \& Comparative Immunology. V.20, n.5. p 353-363, 1996.

AZEDO, M.R.. Influência da leucose enzoótica bovina na atividade oxidativa de leucócitos. 2007. 151 f. Dissertação (Mestrado)- Faculdade de Medicina Veterinária e Zootecnia, Universidade de São Paulo, São Paulo, 2007.

AZEDO, M.R.. Influência do vírus da leucose bovina na resposta imuntária de animais naturalmente infectados. São Paulo, 2010.160f.Tese (Doutorado) - Faculdade de Medicina Veterinária e Zootecnia, Universidade de São Paulo, São Paulo, 2010.

BANNERMAN, D.D.. Pathogen-dependent induction of cytokines and other soluble inflammatory mediators during intramammary infection of dairy cows. Journal of Animal Science, v.87, p 10-25, 2009.

BATISTA, C. F. Dinâmica da resposta imune inata do sistema respiratório de bezerros. 2011. Dissertação (Mestrado) - Faculdade de Medicina Veterinária e Zootecnia, Universidade de São Paulo, 2011. 
BATISTA, C.F.; BLAGITZ, M.G.; BERTAGNON, H.G.; GOMES, R.C.; SANTOS, K.R.; DELLA LIBERA, A. M. M. P.. Evotion of phagocytic function in monocytes and neutrophils blood cells of healthy calves. Journal of Dairy Science. v. 98 p 8882-8888, 2015.

BARRINGTON, G.M.; PARISH, S.M. Bovine Neonatal Immunology. Vet. Clinics of North America: Food Animal Practice, v. 17, n.3. P.463-476, 2001.

BENESI, F.J. Hematologia de bezerros recém-nascidos. Influência da asfixia neonatal, do tipo de parto e da ingestão de colostro sobre a crase sanguínea. Dissertação (Livre docência). Universidade de São Paulo, 1992.

BENESI F.J. Síndrome asfixia neonatal nos bezerros: importância e avaliação crítica. Arquivos da Escola de Medicina Veterinária da Universidade Federal da Bahia, 16:3848, 1993.

BENESI, F. J. Diarréia infecciosa neonatal dos bezerros. In: Simpósio pfizer sobre doenças infecciosas e vacinas para bovinos, São Paulo. Anais... São Paulo: 1996.

BENESI, F.J.; TEIXEIRA, C. M. C.; LEAL, M. L.R.; LISBOA, J. A. N.; BIRGEL JUNIOR, E. H.; BOHLAND, E.; MIRANDOLA, R. M. S.. Eritrograma de bezerras sadias da raça Holandesa, no primeiro mês de vida. Pesquisa Veterinária Brasileira, v.32, p.357-360, 2012a.

BENESI, F.J.; TEIXEIRA, C. M. C.; LEAL, M. L.R.; LISBOA, J. A. N.; MIRANDOLA, R. M. S.; SHECAIRA, C.L.; GOMES, V.. Leukogram of healthy Holstein calves within the first month of life. Pesquisa Veterinária Brasileira, 32, p.352-35, 2012 b.

BERTAGNON, H.G. Avaliação da resposta imune inata respiratória em bezerros sadios durante o segundo trimestre de vida. 2015. Tese (Doutorado) - Faculdade de Medicina Veterinária e Zootecnia, Universidade de São Paulo, 2015.

BERTHO, A. L.; FERRAZ, R.. Citometria de fluxo: princípios metodológicos de funcionamento. In; SALES, M. M.; VASCONCELOS, D. M..Citometria de fluxo: aplicações no laboratório clínico e de pesquisa. São Paulo. Editora Atheneu. 2013. P.3-19.

BESSER, T. E.; GAY, C.C. The importance of colostrum to the health of the neonatal calf. Veterinary Clinics of North America, v.10, p.107-117, 1994.

BIONDO, A. W., LOPES, S.T.A., KOHAYAGAWA, A. TAKAHIRA, R.K., ALENCAR, N.X. Hemograma de bovinos (Bos indicus) sadios da raça nelore no primeiro mês de vida, criados no estado de São Paulo Ciencia Rural vol.28 no.2 Santa Maria Apr./June 1998.

BIRGEL, E. H.; BENESI, F. J. Patologia clínica veterinária. In: BIRGEL, E. H. Hematologia clínica veterinária. São Paulo: Sociedade Paulista de Medicina Veterinária, 1982. p. 2-49.

BORGES, A. S. Avaliação da eficácia da administração de plasma por via intravenosa, como tratamento da falência de transferência de imunidade passiva em bezerros da raça Holandesa.1997. 84f. Tese (Doutorado em Medicina Veterinária)- Faculdade de Medicina Veterinária e Zootecnia, Universidade de São Paulo; São Paulo, 1997. 
BURGOS, R.A.; CONEJEROS, I.; HIDALGO, M. A.; WERLING, D.; HERMOSILLA, C. Calcium influx, a new potential therapeutic target in the control of neutrophil-dependent inflammatory diseases in bovines. Veterinary Immunology and Immunopathology, v, 143, n.1-2, p,1-10. 2011.

BURTON, J. L.; MADSEN, S. A.; CHANG, L.-C.; WEBER, P. S. D.; BUCKHAM, K. R.; VAN DORP, R.; HICKEY, M.-C.; EARLEY, B. Gene expression signatures in neutrophils exposed to glucocorticoids: a new paradigm to help explain "neutrophil dysfunction" in parturient dairy cows. Veterinary Immunology and Immunopathology, v. 105, n. 3-4, p. 197-219, 15 maio 2005.

BRASIL. Ministério da Agricultura, Pecuária e Abastecimento. Bovinos e bubalinos. Disponível em: <http//www.agricultura.gov.br/animal/espécies/bovinos e bubalinos.>Acesso em 30 abr.2017.

CLAEREBOUT, E.; VERCAUTEREN, I. GELDHOF, P; OLBRECHTS, A.; ZARLENGA, D. S.; GODDERIS, B. M.. Cytokine response in immunized and non-immunizes calves after Ostertagia ostertagi infection. Parasite Immunology, v.27, p 325-331, 2005.

CHASE, C. C. L.; HURLEY, D. J.; REBER, A. J. Neonatal immune development in the calf and its impact on vaccine response. Veterinary Clinics of North America, Food Animal Practice, v. 24, p. 87-104, 2008.

CORTESE, V. S. Neonatal Immunology. Veterinary Clinics of North America. Food Animal Practice, v. 25, p. 221-227, 2009.

COSTA J.N., PEIXOTO A.P.C., KOHAYAGAWA A., FERREIRA A.F.M.S.C., CASSETARI M.L. \& CROCCI A.J.. Influência do desenvolvimento etário e da suplementação com vitamina E (acetato de DL-alfa-tocoferol) no metabolismo oxidativo dos neutrófilos de bovinos da raça Holandesa (Bos taurus). Brazilian Journal Veterinary

Research. Animal Science. 41(5):293-298. 2004

COSTA M.C. 2007. Transferência de imunidade passiva e metabolismo oxidativo dos neutrófilos em bezerros das raças Nelore e Limousin. Dissertação (Mestrado) Universidade Estadual de Londrina, Londrina. 84p.

COSTA, M. C.; FLAIBAN, K;K. M. C.; CONEGLIAN, M.M.; DOGNANI, R.; VETTORATO, E.D.; BALARIN, M;R;S;.LISBÔA, J.A.N. Metabolismo oxidativo dos neutrófilos de bezerros das raças Nelore e Limousin nos primeiros quatro meses de vida.

Pesquisa Veterinária Brasileira, v.28, n.9, p.431-436. 2008

COSTA, J.F.R; NOVO, S. M. F.; BACCILI, C. C.; SOBREIRA, N. M.; HURLEY, D. J.; GOMES, V.. Innate response in neonate Holstein heifer calves fed fresh or froze colostrum. Research in Veterinary Science. v.115. p. 54-60, 2017.

CRAIG, N. M.; MILLER, H. R. P.; SMITH, W. D.; KNIGHT, P. A. Cytokine expression in naïve and previously infected lambs after challenge with Teladorsagia circumcinta.

Veterinary Immunology and Immunopathology, v. 20, n.1-2, p. 47-54, 2007. 
CRUVINEL, W.M.; MESQUITA JUNIOR, D.; ARAÚJO, J.A.P.; CATELAN, T;T.T.; SOUZA, A.W.S.; SILVA, N.P.; ANDRADE, L.E.C.. Sistema imunitário - Parte I.

Fundamentos da imunidade inata com ênfase nos mecanismos moleculares e celulares da resposta inflamatória. Revista. Brasileira de Reumatologia. v.50 n.4 São Paulo July/Aug. 2010.

DENG, X.; LI, H.; TANG, Y. W. Cytokine expression in respiratory syncytial vírus-infected mice as measured by quantitative reverse-transcriptase PCR. Journal of Virological Methods, v.107, n.2, p. 141-146, 2003.

DIRKSEN, G.; GRÜNDER, H.D.; STÖBER, M. Rosenberger - Exame Clínico dos Bovinos. In:. DIRKSEN, G. Sistema Digestivo. Rio de Janeiro: Guanabara Koogan, 1993. p. 166-228. DIRKSEN, G.; GRÜNER, H-D; STÖBER, M. Medicina interna y cirugía del bovino. 4ed, Buenos Aires: Inter.-Médica, p:618-625, 2005.

DORÉ, M.; SLAUSON, D.O.; NEILSEN, N. R.. Membrane NADPH oxidase activity and cell size in bovine neonatal and adult neutrophils. Pediatric research. V. 28, N. 4, P.327-330. 1990

EBERHART R. J., PATT JR. J. A. 1971. Plasma cortisol concentrations in newborn calves. American Journal of Veterinary Research, 32: 921-1927.

ELSE, K. L.; FINKELMAN, F. D. Instestinal nematodes parasites, cytokines and effector mechanisms. International Journal for Parasitology, v.28, p.1145-1158. 1998.

FAGLIARI, J.J.; SANTANA, A. E.; CAMPOS FILHO, E.; CURI, P. R. Blood constituents of newborn Nelore cattle (Bos indicus), Holstein cattle (Bos taurus), and Murrah buffalo (Bubalus bubalis). Brazilian Journal of Veterinary Research Animal Science. V.50. 253262 p.1998

FEITOSA, F.L.F. Dinamica do proteinograma e da atividade da gamaglutamiltransferase no soro sanguíneo de bezerros desde o nascimento até um ano de idade e de vacas, antes e aós o parto, da raça Holandesa. Tese (Doutorado) -Faculdade de Medicina Veterinária e Zootecnia, Universidade de São Paulo, São Paulo, 1998.

FEITOSA F.L.F.; BIRGEL E.H.; MIRANDOLA R.M.S.; PERRI S.H.V. Diagnóstico de falha de transferência de imunidade passiva em bezerros através da determinação de proteína total e de suas frações eletroforéticas, imunoglobulinas $\mathrm{G}$ e $\mathrm{M}$ e da atividade da gama glutamil transferase no soro sanguíneo. Ciência Rural 31(2):251- 255, 2001.

FEITOSA, F. L.F., BENESI, F.J..Semiologia de animais recém nascidos. In: FEITOSA, F.L.F Semiologia: a arte do diagnóstico. $3^{\mathrm{a}}$ ed. São Paulo: Editora Rocca,. 2014. P 69-97

FEITOSA, F.L.F.; CAMARGO, D.G.; YANAKA, R.; MENDES, L.C.N.; PEIRÓ, J.R.; BOVINO, F.; LISBOA, J.A.N.; PERRI, S.H.V.; GASPARELLI, E.R.F. Índices de falha de transferência de imunidade passiva (FTIP) em bezerros holandeses e nelores, às 24 e 48 horas de vida: valores de proteína total, de gamaglobulina, de imunoglobulina $\mathrm{G}$ e da atividade sérica de gamaglutamiltransferase, para o diagnóstico de FTIP. Pesquisa Veterinária. Brasileira. 30(8):696-704, 2010. 
FIRTH, M. A.; SHEWEN, P. E.; HODGINS, D. C.. Passive and active components of neonatal innate immune defenses. Animal Health Research Reviews, v.6 p. 143-158. 2005.

FURTADO, V. M. G. Imunofenotipagem em Leishmaniose cutânea -imunohistoquímica como ferramenta para estudar a reação imune e a apoptose em uma série de pacientes com Leishmaniose cutânea no Distrito Federal. Dissertação (Mestrado). Faculdade de Ciências Médicas, Universidade de Brasília, UnB. 2006. 74f.

GARFIAS, C. R. B. Importancia de los linfócitos T $\gamma \delta$ em la respuesta imunitária de los bovinos. Veterinaria México. V. 42, n.1. P. 65-75. 2011.

GODDEN, S. Colostrum Management for Dairy Calves, Veterinary Clinics: Food Animal Practice, 24, pp.19-39, 2008.

GONZÁLEZ-CANO, P.; ARSIC, N.; POPOWYCH, Y. I.; GRIEBEL, P. J.. Two functionally distinct myeloid dendritic cell subpopulations are presente in bovine blood. Developmental and Comparative Immunology, v. 44, n.2, p. 378-388. 2014.

GRAPHPAD SOFTWARE, Inc. (2014) GraphPad Software, Inc . GraphPad Prism Users Guide. La Jolla, CA: GraphPad Software; 2014

GRENCIS, R.K .Cytokine regulation of resistance and susceptibility to intestinal nematode infection- from host to parasite. Veterinary Parasitology, v,100, p. 45-50, 2001.

GRELL, S. N.; RIBER, U.; TJØRNEHØJ, K.; LARSEN, L. E.; HEEGAARD, P. M. H. Agedependent differences in cytokine and antibody responses after experimental RSV infection in a bovine model. Vaccine, v. 23, n. 26, p. 3412-23, 16 maio 2005a.

GRELL, S. N.; TJØRNEHØJ, K.; LARSEN, L. E.; HEEGAARD, P. M. H. Marked induction of IL-6, haptoglobin and IFNgamma following experimental BRSV infection in young calves. Veterinary Immunology and Immunopathology, v. 103, n. 3-4, p. 235-45, 10 fev. 2005b

HAUSER, M. A.; KOOB, B.S.; JAMES, A.R..Variation of neutrophil function with age in calves. American Journal Veterinary Research, v.53, n.3, p.464-473, 1986.

HIGUCHI, R., FOCKLER, C.;DOLLINGER, G.; WATSON, R.. Kinetic PCR analysis: realtime monitoring of DNA amplification reactions. Biotechnology , v.11, n. 9, P.1026-1030. 1993.

HILL, J.A.G. Transferência de imunidade passiva colostral em bezerras neonatas da Região Metropolitana de Curitiba, Palmeira e Carambeí, Estado do Paraná e suas interrelações. Tese (Doutorado), Universidade de São Paulo, 2010.

HOLMGREN, S.; HAGBERG GUSTAVSSON, M.; KUNDEN,A.; WATTRANG, E.. Cytokine m RNA expression in bronchoalveolar lavage cells during Dictyocaulus viviparous infection in calves. Parasite Immunology, v.36, p.78-86,2014.

HOUEK, A.; RUTTEN, V. P. M. G.; KOOL, J.; ARKESTEIJN, G. J. A.; BOUWSTRA, R.J.; VAN RHIJN, I.; KOETS, A. P.. Subpopulations of bovine $\mathrm{WC}^{+}{ }^{+}$T cells rather than CD4 
CD 25 high Fox p3+T celss act as immune regulatry cells ex vivo. Veterinary Research, v.40, n.1, p.1-14, 2009.

IBELLI, A. M. G.. Quantificação de mRNA de genes relacionados à resposta imune em bovinos infectados com endoparasitos do gênero Haemonchus spp. Dissertação (mestrado). Universidade de São Carlos, 2010.

IBGE. INSTITUTO BRASILEIRO DE GEOGRAFIA E ESTATÍSTICA. INDICADORES DO IBGE: ESTATÍSTICA DA PRODUÇÃO PECUÁRIA. 2015. BRASILIA, 2015.

INGALE, S. L.; SINGH, P.; RAINA, O. K.; MEHRA, U. R.; VERMA, A. K.; GUPTA, S. C.; MULIK, S. V. Interferon-gamma and interleukin-4 expression during Fasciola gigantica primary infection in crossbred bovine calves as determined by real -time PCR. Veterinary Parasitology, v. 152, n. 1-2, p. 158-61, 25 mar. 2008.

JAIN, N. C. Schalm's veterinary hematology. 4. ed. Philadelphia: Lea \& Febinger, p.1221, 1993.

KAMPEN, A. H.; TOLLERSRUD, T.; LARSEN, S.; ROTH, J. A.; FRANK, D. E.; LUND, A. Repeatability of flow cytometric and classical measurement of phagocytosis and respiratory burst in bovine polymorphonuclear leukocytes. Veterinary Immunology and Immunopathology, v. 97, n. 1-2, p. 105-114, jan. 2004.

KANEKO, J. J.; MILLS, R., Hematological and blood chemical observations in neonatal notmal and porphyric calves in early life. Cornell Veterinarian, v.60, p.52-60, 1970.

KERESZTES, G.; TAKACS, L.; VILMOS, P.; KURUCZ, E.; ANDO,I.. Monoclonal antibodies detecting components of the bovine immune system in formaldehyde-fixed paraffin-embedded tissue specimens. Veterinary Immunology and Immunopathology, v.52, p. 383-392, 1996.

KIDD, P. Th1/Th2 Balance:The hipotesis, the limitations and the implications for health and disease. Alternative Medicine Review, v.8, n.3. p 232-246. 2003

KONNAI, S.; USUI, T.; OHASHI, K.; ONUMA, M.. The rapid quantitative analysis of bovine cytokinegenes by real-time RT-PCR. Veterinary Microbiology, n. 94, p.283294.2003.

KOWANKO I. C.; FERRANTE, A.. Stimulation of neutrophil respiratory burst and lysossomal enzyme release by human interferon- $\gamma$. Immunology, 62:149. 1987

KUBISTA M.; ANDRADE, J.M; BENGTSSON, M.; FOROOTAN, A.; JONÁK, J.; LIND, K.; SINDELKA, R.; SJÖBACK, R.; SJÖGREEN, B.; STRÖMBOM, L. STAHLBERG, A.; ZORIC, N.. The real-time polymerase chain reaction. Molecular Aspects of Medicine , v. 27,p. 95-125. 2006. 
KNUTSON. K. L.; DISIS, M. L.. IL-12 enhances the generation of tumour antigen-specific Th1 CD4 T cells during ex vivo expansion. Clinical \& Experimental Immunology,v.135, n.2: p.322-329.2004.

LA MOTTE G. B.; EBERHART R. J. 1976. Blood leukocytes, neutrophil phagocytosis, and plasma corticosteroids in colostrum-fed and colostrum-deprived calves. American Journal of Veterinary Research. 37: 1189-93.

LAIDLAW, B.J.; WEIGUO, C.; AMEZQUITA, R. A.; GRAY, S. M.; GUAN, T.; LU, Y.; KOBAYASHI, Y.; FLAVELL, R. A.; KLEINSTEN, S. H.; CRAFT, J. KAECH, S. M..Production of IL-10 by CD4+ regulatory $\mathrm{T}$ cells during the resolution of infection promotes the maturation of memory CD8+ T cells. Nature Immunology. V.16, N.8, P.871879. 2015

LEACH, R. J.; O’NEILL, R. G.; FITZPATRICK, J. L.; WILLIAMS, J.L.; GLASS, E. J.. Quantitative trait loci associated with the immune response to a bovine respiratory syncytial virus vaccine. PloS One, v. 7, n.3p e33526, 2012.

LEUTENEGGER, C. M.; ALLUWAIMIB, A. M.; SMITH, W. L.; PERANID, L.; CULLOR, J. S.. Quantitation of bovine cytokine mRNA in milk cells of healthy cattle by real-time TaqMan 1 polymerase chain reaction. Veterinary Immunology and Immunopathology, v.77, P. 275-287. 2000.

MADUREIRA K.M.. Citocinas IL-1ß, IL-6, TNF- $\alpha$ e IFN-g no sangue e colostro de fêmeas bovinas da raça Holandesa. Importância na transferência de imunidade passiva. Tese (Doutorado) Faculdade de Medicina Veterinária e Zootecnia, Universidade de São Paulo, São Paulo, SP. 85p. 2011

MARCHI, L. F.O papel do interferon-gama na fagocitose imunológica e na produção de espécies reativas de oxigênio por neutrófilos polimorfonucleares de camundongo Tese (Doutorado). Faculdade de Medicina de Ribeirão Preto, Universidade de São Paulo, SP. 151.p. 2010.

MENA, A.; IOANNOU, X. P.; VAN KESSEL, A.; VAN DRUNEN LITTLE-VAN DEN HURK, S.; POPOWYCH, Y.; BABIUK, L. A.; GODSON, D. L. Th1/Th2 biasing effects of vaccination in cattle as determined by real-time PCR. Journal of Immunological Methods, v. 263, n. 1-2, p. 11-21, 1 maio 2002.

MENGE, C. NEUFIELD, B.; HIRT, W.; BAUERFEIND, R.; BALJER, G.; WIELER, L.H. Compensation of preliminary blood phagocyte immaturity in the newborn calf. Veterinary Immunology Immunopathology, n. 62, p.309-321. 1998.

MESQUITA JUNIOR, D.; ARAÚJO, J.A.P.; CATELAN, T.T.T.; SOUZA, A.W.S.; CRUVINEL, W.M.; ANDRADE, L.E.C.; SILVA, N.P. Sistema imunitário-parte II. Fundamentos da resposta imunológica mediada por linfócitos T e B. Revista Brasileira de Reumatologia. v.50 n.5 São Paulo Sept./Oct. 2010.

MEUSSEN, E. N. T.; BALIC, A.; BOWLES, V.. Cells, cytokines and others molecules associated with rejection of gastrointestinal nematode parasites. Veterinary Immunology and Immunopathology, v.108, p121-125, 2005. 
MOREIN, B., ABUSUGRA, I., BLOMQVIST, G. Immunity in neonates. Veterinary Immunology and Histopathology, v. 87 p. 207-213, 2002.

NEWBURGER, P.E.; EZEKOWITZ, R.A.; WHITNEY, C.; WRIGH, J.; ORKIN, S .H. Induction of phagocyte cytochrome $b$ heavy chain gene expression by interferon- $\gamma$.

Proceedings of the National Academis of Science USA.85: 5215. 1988

OHTSUKA, H.; KOBAYASHI, H.; KINOUCH, M.; MAEDA, Y. Comparison of cytokine mRNA expression in pheripheral CD4, CD8, $\gamma \delta$ T cells betweenhealthy Holsten and Japanese Black calves. Journal Animal of Science, v. 85, n.5. p. 575-580, 2014.

OGLIVIE TIMOTHY H. Medicina Interna de Grandes Animais. $1^{\text {a }}$ ed. Porto Alegre: Artes Médicas Sul. 2000.p

ONO, E. A. D.; TANIWAKI, S. A.; BRANDÃO, P. E.. Veterinary Microbiology Short interfering RNAs targeting a vampire-bat related rabies virus phosphoprotein mRNA.

Brazilian Journal of Microbiology . 2017.

PFAFFL. M. W. A new mathematical model for relative quantification in real-time RT-PCR.. Nucleics Acids Research, v.29,n.9. 2001.

PEREIRA, S.I.A.C.P.; ORFAO, A.. Maturação linfóide In; SALES, M. M.; VASCONCELOS, D. M..Citometria de fluxo: aplicações no laboratório clínico e de pesquisa. São Paulo. Editora Atheneu. 2013. P.59-73.

PUECH, C.; DEDIEU, L.; CHANTAL, I.; RODRIGUES, V.. Design and evaluation of a unique SYBR Green real-time RT-PCR assay for quantification of five major cytokines in cattle, sheep and goats Veterinary Research , v.11. n. 65. P.1-14. 2015.

RADOSTITS, O. M.; GAY, C. C.; BLOOD, D. C.; HINCHCLIFF, K. W. Clínica veterinária. 9. ed. Rio de Janeiro: Guanabara Koogan, 2002. p. 56-59.

RAGHUPATHY, R., MAKHSEED, M., AZIZIEH, F., HASSAN, N., AL-AZEMI, M. AND AL-SHAMALI, E. Maternal Th1- and Th2-type reactivity to placental antigens in normal human pregnancy and unexplained recurrent spontaneous abortions. Cellular Immunology, 196, 122-130. 1999.

REBER A.J., LOCKWOOD A., HIPPEN A.R. \& HURLEY D.J. Colostrum induced phenotypic and trafficking changes in maternal mononuclear cells in a peripheral blood leukocyte model for study of leukocyte transfer to the neonatal calf. Veterinary

Immunology. Immunopathology. 109: 139- 150. 200 .

REBER A.J., DONOVAN D.C., GABBARD J., GALLAND K., ACEVES-AVILA M., HOLBERT K.A., MARSHALL L. \& HURLEY D.J. Transfer of maternal colostral leukocytes promotes development of the neonatal immune system I. Effects on monocyte lineage cells. Veterinary Immunology. Immunopathology. 123:186-196. 2008a.

REBER A.J., DONOVAN D.C., GABBARD J., GALLAND K., ACEVES-AVILA M., HOLBERT K.A., MARSHALL L. \& HURLEY D.J. Transfer of maternal colostral 
leukocytes promotes development of the neonatal immune system. II. Effects on neonatal lymphocytes. Veteterinary Immunology. Immunopathology. 123:305- 313. 2008b.

ROITT, I.; BROSTOFF, J.; MALE, D. Immunology. 6th ed. London: Mosby, 2003. 481 p.

ROJAS, J. M.; AVIA, M.; MARTÍN, V.; SEVILLA, N. IL-10: A Multifunctional Cytokine in Viral Infections. Journal of Immunology research. P.-1-14. 2017.

ROMAGNANI S. Induction of TH1 and TH2 responses: a key role for the 'natural' immune response? Immunology Today, v.13, n.10, p379-81. 1992.

SAMPAIO, I. B. Estatística aplicada à experimentação animal. Belo Horizonte: Universidade Federal de Minas Gerais, 1998. 221 p

SAS INSTITUTE. SAS user's guide: statistics. Cary, SAS Institute, 956 p, 2001.

SCHELCHER, F. Infectious bovine respiratory diseases: from immunology to vaccination. In: World Buitracs Congress, 28, 2012, Lisboa. Anais... Lisboa, 2012.

SENOGLES, D.R.; MUSCOPLAT, C.C.; PAUL, P.S. Otogeny of circulanting B lymphocytes in neonatal calves. Research in Veterinary Science. v.25, p.34-36, 1978.

SCHMITTGEM, T.D.; LIVAK, K. J.. Analyzing real-time PCR data by the comparative C(T) method, Nature Protocols. v.3, n. 6, P.1101-1108. 2008

SHECAIRA, C. L.; MADUREIRA, K. M.; GOMES, V.; SEINO, C. H.; SANTOS, R. B.; BOMBARDELLI, J.A.; REIS, G. A.; BENESI, F.J.. Avaliação da transferência de citocinas para bezerros neonatos via ingestão de colostro de fêmeas bovinas. Pesquisa Veterinária Brasileira. v.34. n.12. p.1271-1275. 2014.

STEVENS, A.; LOWE, J. Histologia humana. 2 ed. São Paulo: Editora Manole Ltda. 2001, 408p.

SUETAKE, H.; RATAN SAHA, N.; ARAKI, K.; AKATSU, K.; KIKUCHI, K.; SUZUKI, Y. Lymphocyte surface marker genes in fugu. Comparative Biochemistry and Physiology, Londres, Part D, v.1, n.1, p.102 - 108, 2006.

TAKEDA, K.; OMATA, Y.; KOYAMA, T.; OHTANI, M.; KOBAYASHI, Y.; FURUOKA, H.; MATSUI, T.; MAEDA, R.; SAITO, A. Increase of Th1 type cytokine mRNA expression in peripheral blood lymphocytes of calves experimentally infected with Cryptosporidium parvum. Veterinary Parasitology, v. 113, p. 327-331, 2003.

TÁVORA, J. P. F..1998. Hemograma de bovinos das raças Gir, Girolanda e Holandes, criados no estado de São Paulo: estabelecimento dos valores normais de referência e avaliação das influências de fatores de variabilidade raciais, etários e sexuais. Tese (Doutorado) Faculdade de Medicina Veterinária e Zootecnia da Universidade de São Paulo. São Paulo. 163 p.

TENNANT B., HARROLD, D.; REINA-GUERRA, M. 1974. Haematology of the neonatal calf: erithrocyte and leukocyte values of normal calves. Cornell Veterinarian, 64: 516-32. 
TIZARD, I.R. Imunologia Veterinária - Uma Introdução. $8^{a}$ ed. São Paulo: Editora Roca, 145p, 151p, 233p, 2008.

VALASEK, M. A.; REPA, J.J.. The power of real-time PCR. Advances of Physiology Education, v.29, n.3.P.151-159. 2005.

VOEHRINGER, D.; SHINKAI, K.; LOCKSLEY, R. M. Type 2 immunity reflets orchestrated recruitment of cells commited to IL-4 production. Immunity, v.20, p.267-277, 2004.

WIKSTRÖM, I. Molecular genetics of B- and T-lymphocyte development. Tese (Doutorado) Umea University, USA.2006. 72f 